\title{
Effect of climate change on population dynamics and damage potential of insect pests on oilseed rape
}

\author{
Dissertation \\ zur Erlangung des Doktorgrades \\ der Fakultät für Agrarwissenschaften \\ der Georg-August-Universität Göttingen
}

vorgelegt von

Antje Reinhardt

geboren in Gießen

Göttingen, Mai 2014 
D 7

1. Referentin/Referent: Prof. Dr. Stefan Vidal

2. Korreferentin/Korreferent: Prof. Dr. Andreas von Tiedemann

Tag der mündlichen Prüfung: 22. Mai 2014 
Für meine Großeltern 
"If it's ka it'll come like a wind, and your plans will stand before it no more than a barn before a cyclone"

Stephen King, Wizard and Glass

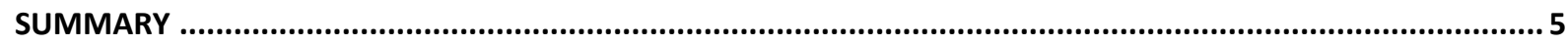

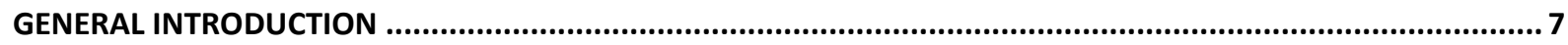

INFLUENCE OF PHENOLOGY OF TWO DIFFERENT OILSEED RAPE (BRASSICA NAPUS L.) VARIETIES ON THE DAMAGE CAUSED BY RAPE STEM WEEVIL (CEUTORHYNCHUS NAPI GYLL.) ..............................................10

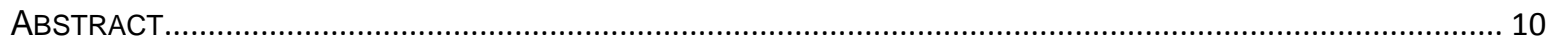

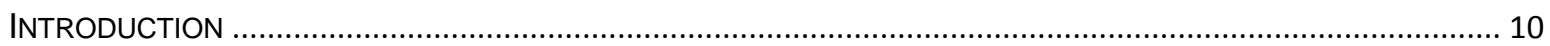

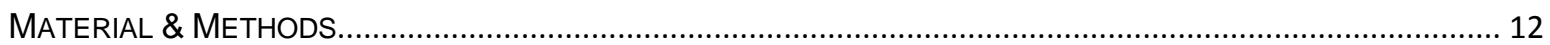

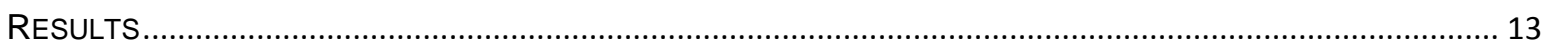

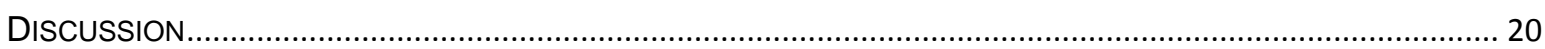

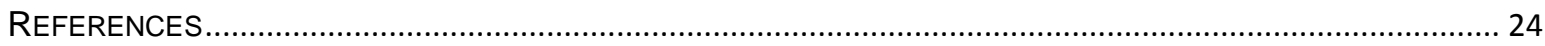

INFLUENCE OF CLIMATE CHANGE INDUCED SOIL WARMING ON OILSEED RAPE - RAPE STEM WEEVIL

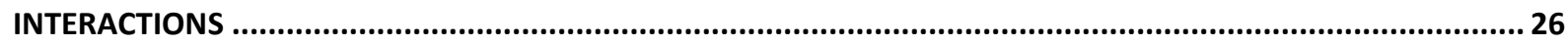

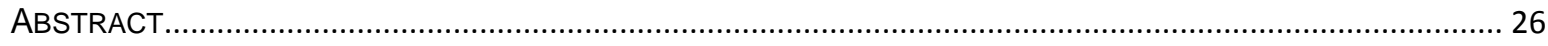

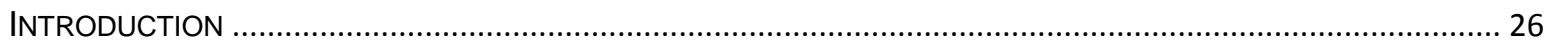

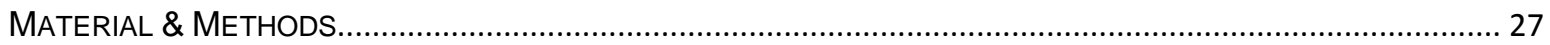

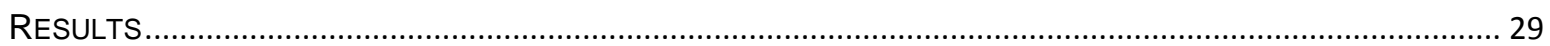

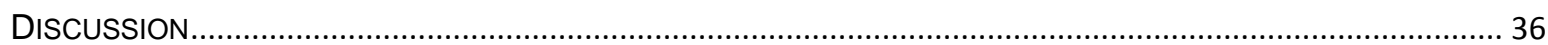

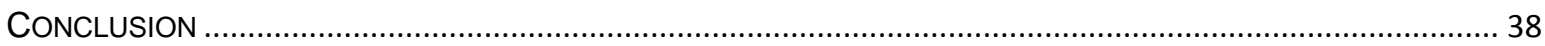

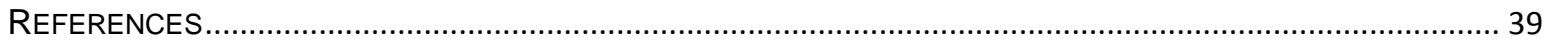

IMPACT OF CLIMATE CHANGE ON THE FERTILITY OF THE RAPE STEM WEEVIL (CEUTORHYNCHUS NAPI GYLL.)

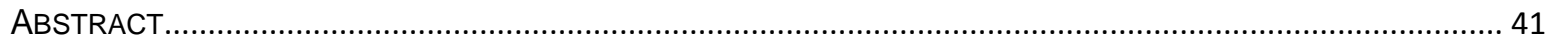

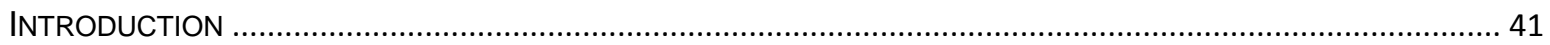

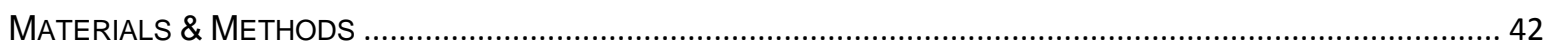

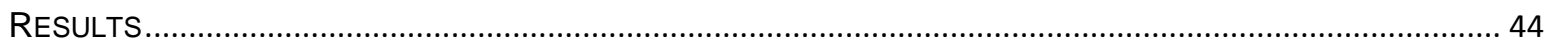

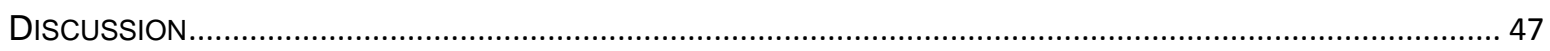

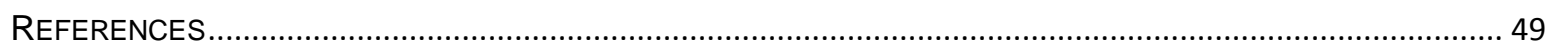

HERBIVORY AND DROUGHT CHANGE VOLATILE EMISSIONS OF OILSEED RAPE (BRASSICA NAPUS L.) ............52

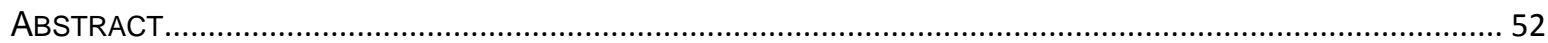

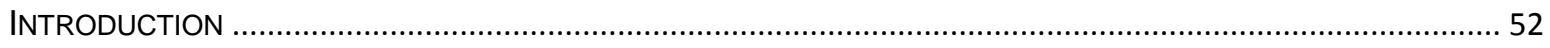

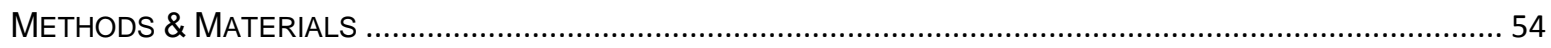

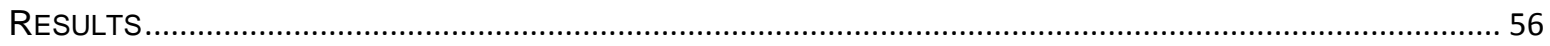

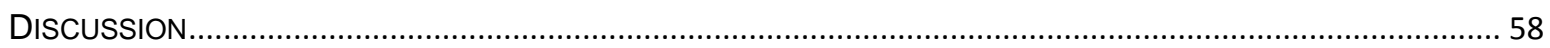

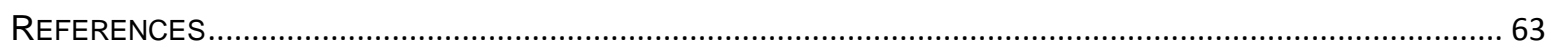

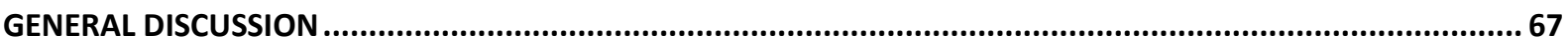

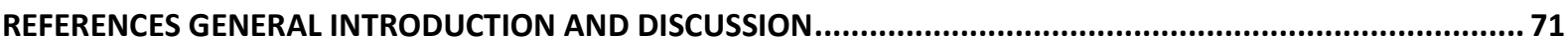

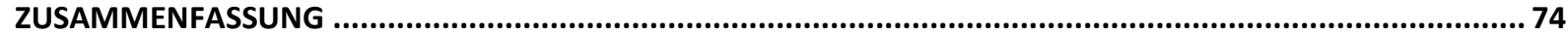

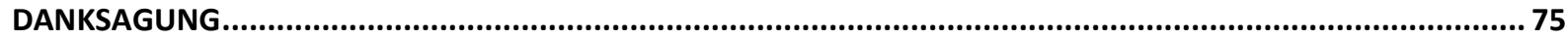

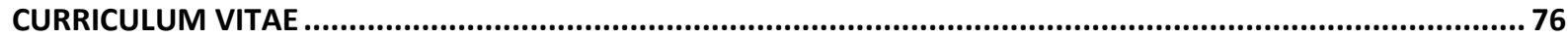

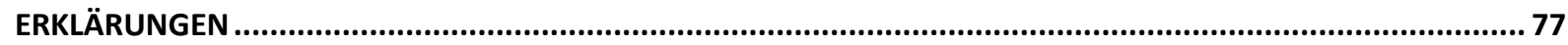




\section{Summary}

Biotic stress such as pests can cause high yield losses in agricultural crop systems. It has been estimated that global warming will increase these rates. Thus, the impact of global warming on the distribution and abundance of insect pests caught the attention of investigators in the last years. However, little is known about the influence of climate change on the interaction between host plants and their insect pests. Current studies make only coarse assumptions about plant responses to their associated pests as consequence of climate change.

The rape stem weevil (Ceutorhynchus napi GYLL.) is the first pest attacking winter oilseed rape (Brassica napus L.) in spring. Warming in spring induced by global warming may affect the pest, the plant and/or the interaction between them. The aim of this thesis was to close existing knowledge gaps about the influence of changing climatic conditions on the interaction between rape stem weevil (RSW) and its host winter oilseed rape (WOSR). Within the research framework "KLIFF - Climate Impact and Adaption Research in Lower Saxony", several field, semi-field and laboratory trials were applied.

The first aim of this study was to assess the influence of WOSR phenology in springtime on damage caused by RSW. Therefore, a field trial was conducted with the WOSR varieties 'Elektra' and 'Favorite' in an alternating split-block design over two consecutive years. Moreover, differences in the damage potential by RSW regarding the initial oviposition were analyzed. The results of this experiment provide new insights into factors influencing the interaction of RSW and its host plant. The variety 'Elektra' with a more rapid development in springtime was earlier infested by RSW adults during the growing season. We showed further that "stem injury index" and "damage index" are not suitable for a reliable assessment of damage potential of RSW although these parameters are used in recent studies. The emigration of RSW third instar larvae was strongly influenced by climatic conditions but not by phenology of the varieties and by the hatching time of larvae.

It is almost unknown, how climate change will influence the interaction between WOSR and RSW. Therefore, a semi-field experiment with three different soil temperature regimes induced by soil warming was set up in a randomized block design. Different plant parameters and the damage potential of RSW through changes in oviposition were recorded. To study the influence of temperature on the date of RSW infestation, plots were artificially infested with RSW cocoons. The emergence of adult emergence was studied with photoeclectors. The results of this experiment suggest that global warming may lead to higher yield losses in order of an earlier beetle emergence. On plant level, the temperature and the variety were predicators for the height of the main shoot which was positively influenced by these factors. Height as well as soil temperature influenced the infestation level of the RSW larvae: taller plants and warmer plots led to an increased abundance of RSW larvae.

In greater extent, studies were conducted in the laboratory to explain more in detail the biology of RSW's. In order to analyze the effect of temperature on the oviposition, survival rate, longevity and egg development of RSW, several trials were carried out. Three average daily temperatures were assessed at constant and varying regimes. Varying or constant temperature regimes with the same mean daily temperature differed with regard to insect developmental time. Varying temperature regimes resulted in an increased oviposition by RSW adults compared to constant temperatures. Consequently, temperature regimes with the same mean daily temperature should be treated with 
care. Another point is the mortality rate of eggs. More eggs died at a constant temperature regime compared to a varying temperature regime. We suggest that this fact must be taken into account when trials with constant temperature regimes are performed.

In the last experiment, the volatile emission of oilseed rape plants upon stress through herbivory by RSW adults or drought was compared to the emission of non-stressed plants. In addition, plant parameters of well-irrigated plants and plants exposed to drought stress were recorded. The results showed that volatile emission significantly differed between control and stressed plants. Stressed plants emitted a higher number of volatiles. Nevertheless, the volatile profiles of stress through herbivory or drought did not result in the same quality and quantity. Regardless to the volatiles, the drought stress had an obviously impact on plant height and fresh weight. The weight of stressed plants was greatly reduced compared to the weight of well-irrigated plants.

In summary, this thesis presents new methodology in RSW research. In addition, knowledge gaps of detailed biological question in the interaction of RSW'S and WOSR were closed. The result of this thesis further suggests that a higher temperature may lead to an increased yield loss in WOSR caused by RSW. 
"Learn from yesterday, live for today, hope for tomorrow. The important thing is to not stop questioning." (Albert Einstein, Relativity: The Special and the General Theory)

\section{General Introduction}

Climatic conditions have changed over the last decades (Karl and Trenberth, 2003; Gutierrez et al., 2008; Musolin et al., 2010; IPCC, 2012). A main focus of current research is to predict changes in temperature regimes in the future. It is estimated that climate warming due to anthropogenic increase of greenhouse gases will raise the average surface temperature on the earth by 2 to $5^{\circ} \mathrm{C}$ during the next 100 years (Wigley and Raper, 2001). In the last 60 years, average temperatures have increased by $1.3^{\circ} \mathrm{C}$ in Lower Saxony (Haberlandt et al., 2010). The regional climate models REMO and CLM predicted a further increase of $2.5^{\circ} \mathrm{C}$ by 2100 in comparison to the baseline period $1971-2000$ (Klimaschutz, 2012).

\section{Effects of an increasing temperature on insects}

It is expected that insect herbivores and their interactions with host plants might be affected if temperatures increase (Jalali et al., 2010, Kocmánková et al., 2011). A changing climate has a major impact on processes influenced by temperature such as insect developmental time (Keena and Moore, 2010), spatial distribution (Gutierrez et al., 2008), behavior, survival and reproduction of insects (Bale et al., 2002). Recent studies surveyed the effects of a changing climate on insects and biological control of insects (Estay et al., 2009; Westwood and Blair, 2010; Gerard et al., 2013). For example, there are already extended flight periods for butterflies (Westwood and Blair, 2010) and predictions that pests will follow their hosts to other climate regions (Gerard et al., 2013). Previous studies investigating the effects of temperature on insect herbivores and their interaction with plants revealed that a shorter generation time of insects could lead to an enhanced population growth (Steinbauer et al., 2004; Dalin, 2011).

Climate and its variability will also have an impact on agronomic decisions (Eitzinger et al., 2010).In the last years, the interest of researchers on the effect of a changing climate on plants and their interaction with insects (Bale et al., 2002; Olfert and Weiss, 2006) or fungal diseases (Chakraborty et al., 2000; Garrett, 2006) has increased. Special focus is drawn on agricultural plants with interactions of their associated pests (Golizadeh et al., 2007; Gutierrez et al., 2008; Jaramillo et al., 2009; Wilstermann and Vidal, 2013). Recently, winter oilseed rape (WOSR) (Brassica napus L.) has received more attention in various studies with regard to climate change (Qaderi et al., 2006; Peltonen-Sainio et al., 2009). Qaderi et al. (2006) described the effect of elevated carbon dioxide as well as increased temperature and drought stress on WOSR. Peltonen-Sainio et al. (2009) focused on the regional importance of summer oilseed rape in case of warmer temperatures in northern areas. However, almost nothing is known about the interaction between WOSR and the rape stem weevil (RSW) (Ceutorhynchus napi Gyll.) with regard to a changing climate.

\section{Biology of oilseed rape and its pests}

WOSR is one of the most important oil plants grown in Germany. The seeds are extruded for oil, which is used for industrial purposes such as biofuel or lubricants. The side product so called "colza cake" is 
incorporated into animal nutrition (Tripathi and Mishra, 2007). The remaining plant parts can be used as straw in heating systems for renewable energy (Sander and Andrén, 1997). The annual production of WOSR in Germany was between 3.6 to 6.3 Mio t in the last 10 years (Eurostat 2012). Herbivory of various insects can lead to substantial yield losses in every season (Alford, 2011).

The RSW is the first pest attacking WOSR after winter. In the last century, the cultivation area of WOSR has increased in Germany so that the RSW become more and more important (Günthart, 1949; Bartlet, 1996). The adult beetles overwinter in the soil of WOSR fields and emerge at a $6^{\circ} \mathrm{C}$ soil temperature threshold in springtime (Juran et al., 2011). The adults are capable of flying at a $10^{\circ} \mathrm{C}$ air temperature (Johnen et al., 2010). The females lay their eggs into the stem of WOSR shoots (Büchi, 1996). Oviposition is the most significant part of the RSW life cycle in terms of plant damage (Günthart, 1949).

\section{Influence of a changing climate on RSW behavior}

The RSW eggs hatch depends, as well as other insect species, on temperature (Günthart, 1949). The larvae start feeding on the degraded stem pith (Juran et al., 2011) which might enlarge the damage. Both WOSR and RSW are poikilotherms and thus highly temperature dependent. Certain temperature regimes are specific to fulfill different life stages for insects (Satar et al., 2005). Consequently, the emergence of RSW will be more important if temperature increases in the future. However, studies investigating the temperature requirements for RSW development are missing in details.

For insects, particular models called day-degree were calculated (Pruess, 1983; Higley et al., 1986). These models assume that a sum of constant temperatures over a certain threshold temperature is needed to accomplish different life stages (Higley et al., 1986; Gilbert and Raworth, 1996). Another hypothesis is that insects are not subjected to constant temperatures in natural habitats (Stinner et al., 1974; Hagstrum and Milliken, 1991). Therefore, constant and varying temperature regimes should be included in experimental set ups. Beside temperature, there are other factors affected by a changing climate. A change for the distribution of precipitation could lead to less rain in the summer, but more in the winter time (IPCC, 2012). As the host quality plays a big role in pest-host interactions, an altered water status of plants may change the infestation level of insect pests due to chemical signals.

\section{Volatiles}

Insects chose their host by visual and semiochemical stimuli (Cook et al., 2007). They are able to discriminate different host plants through odors emitted by plants. As they use these cues to locate their hosts, they select their hosts based on the quantity and the blend of volatiles. For example, the common 1-hexanol has been shown to be either attractant or repellent to the insects, depending on its release rate (Smart and Blight, 1997). Water stress seems to directly affect volatile release (Takabayashi et al., 1994). Due to elevated levels of volatiles used in host location, water-stressed plants will be easier to locate by their associated herbivores compared to non water-stressed plants (Paré and Tumlinson, 1999). Beside the pests, their parasitoids may also be affected as they use the volatiles of infestation to locate their own host (Veromann, 2013). Consequently, herbivory can be positively or negatively influenced by the stress level of the host, which changes the population dynamics of crop pests (Stavrinides et al., 2010). Although the number of studies investigating the role of volatiles increased in the last years (Simpson and McQuilkin, 1976; Finch, 1978; Cole, 1980; Visser, 1986; Takabayashi et al., 1994; Blight et al., 1997; Paré and Tumlinson, 1999; Dicke and Loon, 2000; 
Boer et al., 2004; Dudareva et al., 2004; Holopainen and Gershenzon, 2010), there are still knowledge gaps regarding the volatile emission of WOSR and its effect on RSW in case of climate change related drought stress.

\section{Objectives}

So far, very little is known about the interaction between WOSR and WSR with regard to a changing climate. To date, there are only few studies about the behavior of RSW under changing climate conditions (Eickermann et al., 2014). Moreover, empirical studies investigating the temperature requirements for RSW development are missing. Therefore, this study was based on temperature depending stages of RSW and the interaction with the host plant WOSR.

To study the interactions between WOSR and its associated pest in changing climatic conditions, different experiments were carried out. Therefore, the influence of WOSR phenology on the oviposition of RSW was investigated at a field scale. Another task was to analyze the development of plants and the damage potential of the oviposition. Moreover, new parameters were introduced to assess the damage potential of RSW.

In a semi-field experiment, the influence of soil warming on the RSW abundance was recorded in terms of emergence date. In addition, how soil temperature interacts with plant growth was investigated. We aimed at assessing if an earlier development of the plant will lead to an earlier infestation by the pest. Another major focus was the effect of soil temperature or WOSR variety and on the damage potential of RSW.

Biological models play an important role to predict the occurrence of pests. Data regarding RSW are still missing. One aim of this thesis was to investigate the influence of different constant and varying temperature regimes on oviposition, egg load, survival rate, longevity and egg development of RSW. Moreover, headspace analysis of volatile emissions by WOSR plants with and without stress were performed. The volatile profiles should clarify how control plants differ between herbivore-infested plants, and drought-stressed plants. Finally, the influence of drought stress on plant height and weight was analyzed. 


\title{
Influence of phenology of two different oilseed rape (Brassica napus L.) varieties on the damage caused by rape stem weevil (Ceutorhynchus napi GYLL.)
}

\author{
A. Reinhardt ${ }^{1}$, B. Ulber ${ }^{1}$ and S. Vidal ${ }^{1}$ \\ ${ }^{1}$ Georg-August University, Department of Crop Sciences, Agricultural Entomology, Grisebachstr. 6, \\ 37077 Goettingen, Germany, email: svidal@gwdg.de
}

\section{Abstract}

1. The time when rape stem weevil Ceutorhynchus napi GYLL. females lay their eggs into the stem of oilseed rape is important. Interactions of the host plant and the pest were observed in terms of the damage potential.

2. Two varieties of oilseed rape were used to examine the effects of the developmental stage of plants on the potential damage. All plants were infested by the rape stem weevils independent of the plant developmental stage. The stem length played a major role for the attractiveness of the plants.

3. The earlier developed variety was preferred for the first sampling dates, but this altered with time. Finally, the late variety was affected more by the infestation of Ceutorhynchus napi.

4. The "stem injury index" and the "damage index" both depend on the length of the plants. These are good estimates for the damage potential to compare plants only at one point in time. An estimation of the proportion of stunted plants and the degree of bent plants as well as non-damaged plants served as criteria for the damage potential. For a continuous and permanent observation, more parameters need to be developed for a reliable conclusion of damage potential.

5. There was a discrepancy in the number of recovered Ceutorhynchus napi larvae in the stem and in the number of emigrating larvae. This possibly indicates resources were not sufficient for all larvae in the stems during their development.

Keywords: damage potential, oviposition, larval emigration, stem injury index, plant growth stage

\section{Introduction}

On a world scale, the oilseed rape crop area approaches 34 million ha, about 6 million ha of which are grown in Europe (FAO, 2014). The importance of oilseed rape for Germany is represented in the number of cultivated acreage. 1.3 million ha of oilseed rape were harvested in the year 2012 in Germany with a yield of 4.8 million tonnes (FAO, 2014). Oilseed rape (Brassica napus L.) is used as an oil plant with a broad use of its plant parts. The oil can be used for industrial lubricants as biofuel (Tuck et al., 2006) or human nutrition, since breeders reared varieties without unhealthy erucic acid and low glucosinolate content in the seeds (Björkman et al., 2011). These special varieties are known as 'double-low' in Europe and called Canola in Canada (Lamb, 1989). The colza cake is used for 
animal nutrition (Tripathi and Mishra, 2007). The straw can be part of an energy source for heating systems (Sander and Andrén, 1997).

The yield of winter oilseed rape (WOSR) is always at risk to be reduced by herbivorous insects (Lamb, 1989). The main insect pests of WOSR are oligophagous, feeding only on the plant family Brassicaceae (Bartlet, 1996) and therefore highly specialized in dealing with the glucosinolate levels in Brassica crops. These pests become more important with increasing acreage of WOSR within a certain area (Bartlet, 1996). Starting in spring, the rape stem weevil (RSW) (Ceutorhynchus napi Gyll.) is the first pest appearing (Günthart, 1949) and can reduce the yield of WOSR significantly (Dechert and Ulber, 2004). The RSW is distributed all over continental Europe (Juran et al., 2011) and have a single generation annually (Juran et al., 2011). The immigration into WOSR starts at a threshold of 10 ${ }^{\circ} \mathrm{C}$ air temperature (Günthart, 1949). The flight of adult RSWs also depends on other weather conditions, like maximum day temperature, daily mean temperature, sunshine duration, wind speed and precipitation (Johnen et al., 2010).

After immigration to new WOSR crops, a short maturation feeding begins before the females lay their eggs inside the stem (Johnen et al., 2010). Due to histological changes of the cortex, the pith exhibits porous cavities even before the larvae hatch (Günthart, 1949). After larval hatching, the larvae feed on the stem pith until they reach the third and last instar. They bore out of the stem tissue and pupate within the top soil layers directly at the plant. The larvae build an earthen cocoon in which they pupate, until the adults leave it around December followed by quiescence (Günthart, 1949). First movements in the soil are recorded at a soil temperature of $6^{\circ} \mathrm{C}$ (Günthart, 1949). Afterwards, they wait in lower soil layers until air temperature reaches the threshold of $10^{\circ} \mathrm{C}$ to fly into the new crop (Günthart, 1949). The feeding damage made by adults is not significantly severe (Juran et al., 2011) and the main damage occurs by oviposition of the females. The cavities lead to high damage as the transport of assimilates is interrupted. The mining of the larvae in the stems does not result in more damage. The infested stems can split open and have a dumose appearance through the development of more lateral shoots (Juran et al., 2011). The main stems appear bent, twisted or distorted (Juran et al., 2011). The potential damage can be influenced by the time female weevils are colonizing their host and laying their eggs. Vice versa, the phenological stage of the host is an important factor for the degree of damage (Lamb, 1989). As beetles are waiting in the soil, they can react faster to early rising temperature in contrast to WOSR. Subsequently, the immigration can occur to less developed plants (Gutierrez et al., 2008; Westwood and Blair, 2010).

In this study, we hypothesized that i) the plant phenology influences the oviposition of RSW, ii) the oviposition of RSW harms less developed plants more than more advanced plants and iii) we focused on finding new plant parameters for the damage potential of RSW, which can contribute to a better understanding of host plant-insect interaction. The phenology was tested with two varieties in an open field trial with natural infestation. We estimated that a late flowering variety with a delayed development will be more damaged with early infestation compared to an early flowering variety with an advanced development in spring. 


\section{Material \& Methods \\ Study sites and plant material}

This study was conducted as a field trial with two WOSR varieties. The varieties 'Elektra' and 'Favorite' were selected because of the highest disparity concerning spring development. The trial was conducted for two consecutive years. Variety 'Elektra' is an early flowering hybrid. In contrast to 'Elektra', 'Favorite' is an open-pollinated cultivar with a delayed development in accordance with the rating scale of the flowering start by the German Federal Office for Plant Varieties (Bundessortenamt). Both varieties were 'double-zero' cultivars. The field trials were carried out in two conventionally managed fields in the region of Goettingen $\left(51.56571^{\circ} \mathrm{N} 9.94692^{\circ} \mathrm{E}\right)$, Germany. Pre-crop was winter barley, respectively. The fields were ploughed and harrowed before sowing. The sowing dates were $20^{\text {th }}$ of August 2010 and $22^{\text {nd }}$ of August 2011. These dates are considered to be the optimal sowing dates for the region. The sowing density for 'Elektra', as a vigorous hybrid, was 70 seeds per $\mathrm{m}^{2}$ and for the variety 'Favorite' 80 seeds per $\mathrm{m}^{2}$ in each year. All seeds were treated with a fungicide coating (Dimethomorph). Plant nutrition and protection, except insecticides, were applied according to good agricultural practice.

In 2010/11 and 2011/12 the experimental set-up was conducted as an alternating split-block design with the two varieties. Only in 2011/12, there was a technical border to the former WOSR field of 12.5 $\mathrm{m}$. This border consisted of a mixture of both varieties. To reduce orientation problems of the beetles, the minimum distance to the nearest WOSR field was $500 \mathrm{~m}$. Plot sizes varied from $656 \mathrm{~m}^{2}$ in 2010 to $200 \mathrm{~m}^{2}$ in 2011.

\section{Plant parameters}

After a harsh winter in 2012, the number of overwintered plants per $\mathrm{m}^{2}$ was counted four times in each plot with the aid of a wooden frame $(1 \mathrm{~m} \times 1 \mathrm{~m})$. The parameter 'plants per $\mathrm{m}^{2}$ ' was checked for significant differences with a one-way ANOVA followed by a Tukey HSD (Honestly Significant Difference) test as post-hoc test. At each sampling date, the plants were randomly taken from the field to the laboratory for analysis. At each sampling date, the growth stage $(\mathrm{BBCH})$ was assessed after Lancashire et al. (1991). The data set of growth stages is ordinal scaled; therefore, a Mann-Whitney U-test was performed. Additionally, the length of the main shoot $(\mathrm{cm})$ was determined. A one-way ANOVA followed by Tukey HSD was conducted for the length of the main shoot.

\section{Damage caused by RSWs}

The shoots were opened and the numbers of RSW eggs and larvae were counted within the main stem. The following symptoms were also assessed: length of interior stem cavities caused by RSW oviposition, bursts at the main shoot, stunting and bending of the main shoot. Additionally, a stem injury coefficient and an index for damage were calculated. The stem injury coefficient determines the length of stem cavities caused by RSW's in relation to the total stem length (Eickermann et al., 2011). In the same way, the parameter of bursts at the main shoot was transformed into an index for RSW damage. The cumulative burst length was divided by the total stem length. These percentages were transformed by arcsine transformation $(\Delta p=\operatorname{arc} \sin \sqrt{ } p)$ prior to a one-way ANOVA with a Tukey HSD (Köhler et al., 2007).

Stunted plants were counted and a chi-square test was utilized to find significant differences in the frequencies of this characteristic features. The symptoms of bending were classified in four categories 
and analyzed with Mann-Whitney U-test for differences. These categories display the severity of the bending by none, light, medium and heavy bending.

\section{Beetle abundance and emigration}

The abundance of RSWs was recorded with four yellow water traps per field and year filled with water to which a detergent was added to reduce the surface tension. Finally at the end of the season, the number of emigrating larvae was assessed. Six plants per three plots were tested in 2011 and six plants in four plots were tested in 2012. Each plant was cut free of adjacent plants and surrounded by water traps with a detergent. The traps were emptied weekly and the drowned RSW larvae were counted. The number of emigrating larvae per plant and variety was analyzed with a multiple ANOVA followed by a Tukey HSD test.

\section{Statistical analyses}

Each year was analyzed separately. As the data was normally distributed and the variances were homogenous, a one-way ANOVA was conducted. The results were assumed to be significant with a $p$ value of $p \leq 0.05$. The software STASTICA version 10.0 (StatSoft, Tulsa, OK, USA) was used to perform the statistical analyses.

\section{Results}

\section{Plant parameters}

In early spring 2012 before the RSWs immigrated, the varieties 'Elektra' and 'Favorite' showed no differences in the plant density between different plots nor between both varieties $(F=52$, d.f. $=30, p$ $=0.66$ ).

Both varieties could differ in their developmental stages as described by the German Federal Office for Plant Varieties (Bundessortenamt). The statistic shows a significant difference at sampling date T2 in 2011 at the end of elongation (Mann-Whitney. $U$ test: $Z=2.16, p<0.05$ ). In 2012, the difference was noted in the later stages, but developed for a longer period. There were significant differences at the start of emergence of buds (Mann-Whitney. $U$ test: $Z=2.02, p<0.05$ ) and end of flowering (MannWhitney. $U$ test: $Z=2.16, p<0.05)$.

Table 1 Median value $( \pm$ SEM) of plant growth stages $(\mathrm{BBCH})$ of two oilseed rape varieties 'Elektra' and 'Favorite' at five sampling dates in 2011 and 2012. Within the same date, means followed by the same letter are not significantly different (Mann-Whitney U-test, $\mathrm{p}<0.05$ )

\begin{tabular}{|c|c|c|c|c|c|c|c|c|c|c|}
\hline & \multicolumn{2}{|r|}{ T1 } & \multicolumn{2}{|c|}{ T2 } & \multicolumn{2}{|r|}{ T3 } & \multicolumn{2}{|r|}{ T4 } & \multicolumn{2}{|r|}{ T5 } \\
\hline 2011 & \multicolumn{2}{|c|}{04 April } & \multicolumn{2}{|c|}{11 April } & \multicolumn{2}{|c|}{18 April } & \multicolumn{2}{|c|}{26 April } & \multicolumn{2}{|c|}{02 May } \\
\hline Elektra & 51 & $( \pm 0.00) \mathrm{A}$ & 51 & $( \pm 0.00) \mathrm{A}$ & 51 & $( \pm 2.00) \mathrm{A}$ & 65 & $( \pm 0.50) \mathrm{A}$ & 67 & $( \pm 0.00) \mathrm{A}$ \\
\hline Favorite & 50 & $( \pm 0.25) A$ & 50 & $( \pm 0.00) \mathrm{B}$ & 51 & $( \pm 0.25) A$ & 64 & $( \pm 0.28) A$ & 67 & $( \pm 0.82) \mathrm{A}$ \\
\hline 2012 & \multicolumn{2}{|c|}{19 March } & \multicolumn{2}{|c|}{26 March } & \multicolumn{2}{|c|}{02 April } & \multicolumn{2}{|c|}{30 April } & \multicolumn{2}{|c|}{14 May } \\
\hline Elektra & 51 & $( \pm 0.29) A$ & 51 & $( \pm 0.31) A$ & 53 & $( \pm 0.63) A$ & 69 & $( \pm 0.50) A$ & 77 & $( \pm 0.48) \mathrm{A}$ \\
\hline Favorite & 50 & $( \pm 0.25) \mathrm{A}$ & 51 & $( \pm 0.00) \mathrm{A}$ & 51 & $( \pm 0.25) \mathrm{B}$ & 62 & $( \pm 1.68) \mathrm{B}$ & 75 & $( \pm 0.90) \mathrm{A}$ \\
\hline
\end{tabular}


For the parameter length of main shoot, 'Elektra' showed an advance of 'Favorite' in growth. For the first two sampling dates in 2011 no differences were found $(T 1 F=1.91, p=0.08, T 2 F=3.33, p=$ 0.08 , d.f. $=6$ respectively). In 2012, significant differences were indicated late at the sampling date $\mathrm{T} 4$ $(F=6.45$, d.f. $=6, p<0.05)$, but not for the other sampling dates $(\mathrm{T} 1 \mathrm{H}=0.33, \mathrm{p}=0.6, \mathrm{~T} 2 \mathrm{~F}=4.35, \mathrm{p}$ $=0.65, \mathrm{~T} 3 \mathrm{~F}=2.72, \mathrm{p}=0.09, \mathrm{~T} 5 \mathrm{H}=2.08, \mathrm{p}=0.15$, d.f. $=6$ respectively).

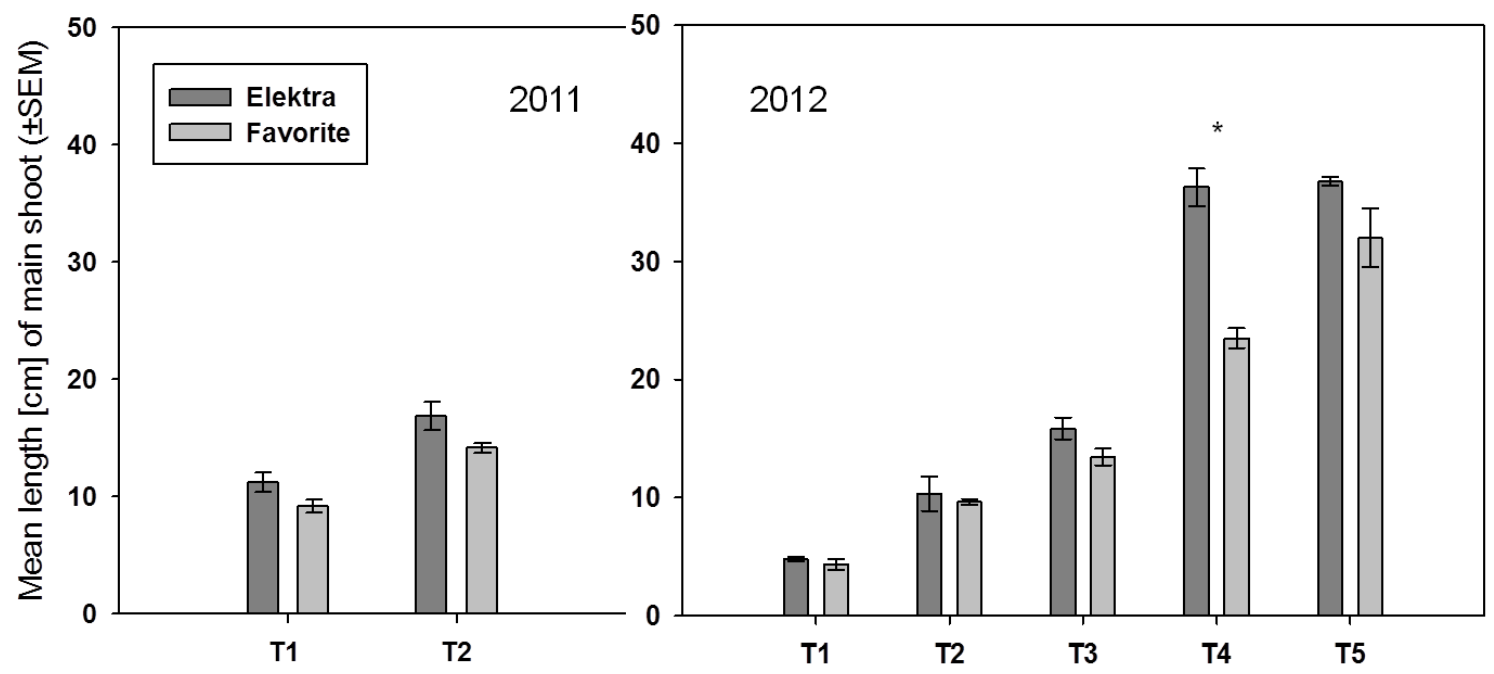

Figure 1: Mean length of main shoot of the varieties 'Elektra' and 'Favorite' displayed for the year 2011 at two dates and 2012 at five dates ( ${ }^{*}$ significant difference with $p<0.05$ between varieties within one sampling date; one-way ANOVA, Tukey HSD)

\section{Damage caused by RSWs}

The number of extracted eggs were not different between the varieties for the year 2011 ( $T 1 \mathrm{~F}=1.88$, $\mathrm{p}=0.12, \mathrm{~T} 2 \mathrm{~F}=10.37, \mathrm{p}=0.41, \mathrm{~T} 3 \mathrm{~F}=7.55, \mathrm{p}=0.18, \mathrm{~T} 4 \mathrm{~F}=0.25, \mathrm{p}=0.76$ and T5 $\mathrm{F}=0.04, \mathrm{p}=$ 0.43 ; d.f. $=6$ respectively). Also, the number of found larvae did not differ significantly $(\mathrm{T} 1 \mathrm{H}=0.11, \mathrm{p}$ $=0.77, \mathrm{~T} 2 \mathrm{~F}=2.63, \mathrm{p}=0.49, \mathrm{~T} 3 \mathrm{~F}=1.13, \mathrm{p}=0.53, \mathrm{~T} 4 \mathrm{~F}=9.27, \mathrm{p}=0.10$ and $\mathrm{T} 5 \mathrm{~F}=10.07, \mathrm{p}=0.13$; d.f. $=6$ respectively).

In 2012, the number of laid eggs was significantly greater in 'Elektra' for the first sampling date T1 ( $F=$ 0.12 , d.f. $=6, p<0.05)$. Over the last four sampling dates, the eggs were extracted with no differences in their quantity $(\mathrm{T} 2 \mathrm{~F}=12.21$, d.f. $=6, p=0.69, \mathrm{~T} 3 \mathrm{H}=1.33, \mathrm{p}=0.24, \mathrm{~T} 4 \mathrm{~F}=0.08$, d.f. $=6, \mathrm{p}=0.24$ ). All larvae hatched within the time between T4 and T5. For the last sampling date, no data for eggs were collected. The first hatched larvae were found in T4. There were no significant differences between the varieties for the number of found larvae $(T 4 \mathrm{H}=0.00, p=1.00, T 5 F=2.29$, d.f. $=6, p=$ 0.37). 


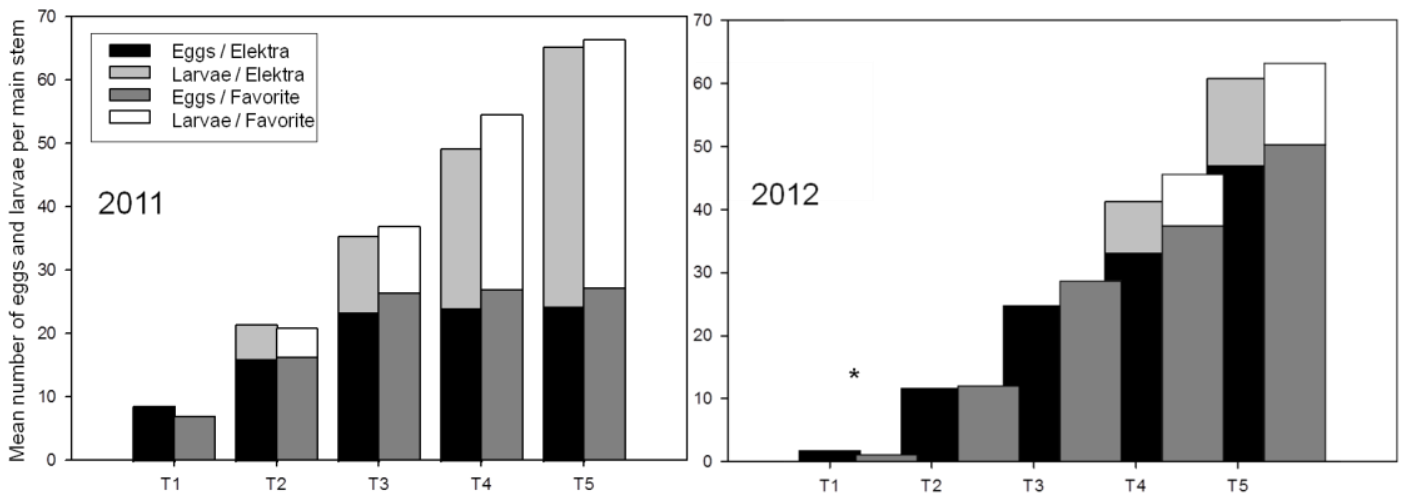

Figure 2: Abundance of eggs and larvae in the main shoot in the varieties 'Elektra' and 'Favorite' in $2011\left({ }^{*}=\right.$ significant differences with $p<0.05$ between varieties within one date; One-way ANOVA, Tukey HSD)

In 2011, there were no differences for the parameter "stem injury index" (T1 F $=0.00$, d.f. $=6, p=$ $0.73, \mathrm{~T} 2 \mathrm{~F}=0.00$, d.f. $=6, \mathrm{p}=0.08$ ). The "stem injury index" differed significantly between 'Elektra' and 'Favorite' only at T4 in $2012(F=0.01$, d.f. $=6, p<0.05)$. All other dates showed a higher stem injury coefficient in 'Elektra' but not significantly different ( $T 1 \mathrm{~F}=0.02, p=0.13, \mathrm{~T} 2 \mathrm{~F}=0.00, p=0.43$, $\mathrm{T} 3 \mathrm{~F}=0.00, \mathrm{p}=0.50$ and $\mathrm{T} 5 \mathrm{~F}=0.00, \mathrm{p}=0.93$, d.f. $=6$ respectively).
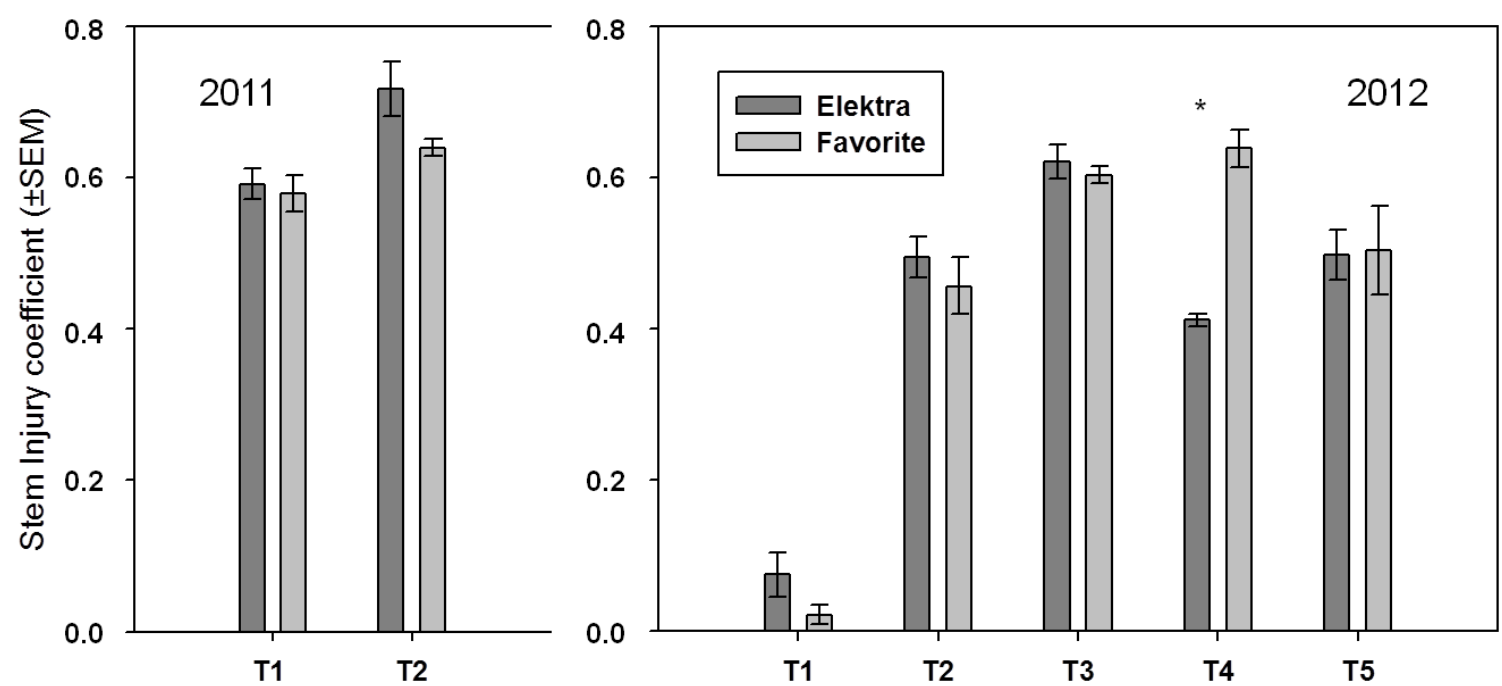

Figure 3: Stem injury coefficient caused by RSW larvae in the varieties 'Elektra' and 'Favorite' in two consecutive years $\left({ }^{*}=\right.$ significant differences with $p<0.05$ between varieties within one date; One-way ANOVA, Tukey HSD) 
Stunting was measured during the season. The varieties showed no differences in their degree of stunted growth in the year 2011 ( $\mathrm{T} 4 \mathrm{x}^{2}=0.46$, d.f. $=1, \mathrm{p}=0.50$ ). 'Elektra' had a lower proportion of stunted plants than 'Favorite' at only one sampling date in 2012. Notably, the statistical analysis showed that there was a significant difference at sampling date T4 in 2012 (T4 $x^{2}=30.25$, d.f. $=1, p<$ $0.05)$. At sampling date $T 5$ this parameter did not differ anymore $\left(T 5 x^{2}=1.07\right.$, d.f. $\left.=1, p=0.30\right)$.

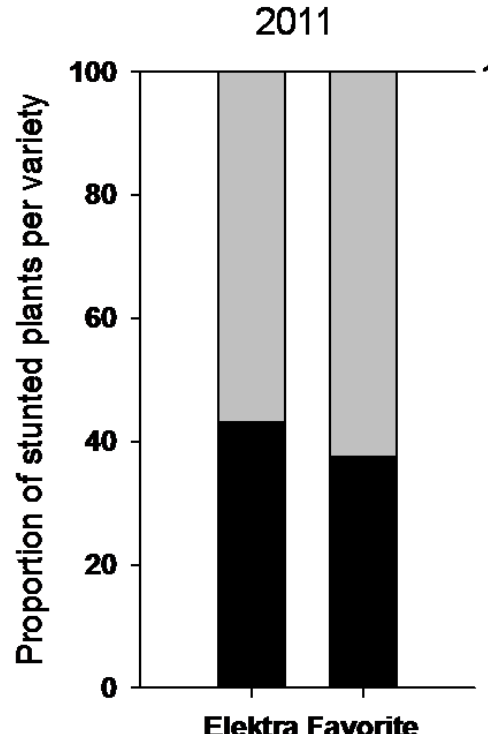

T4

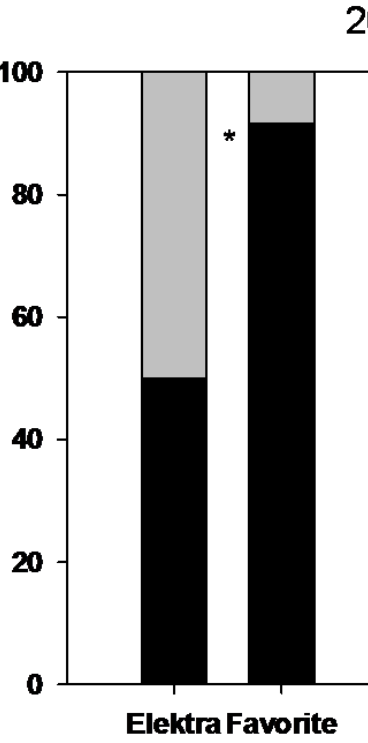

T4
2012

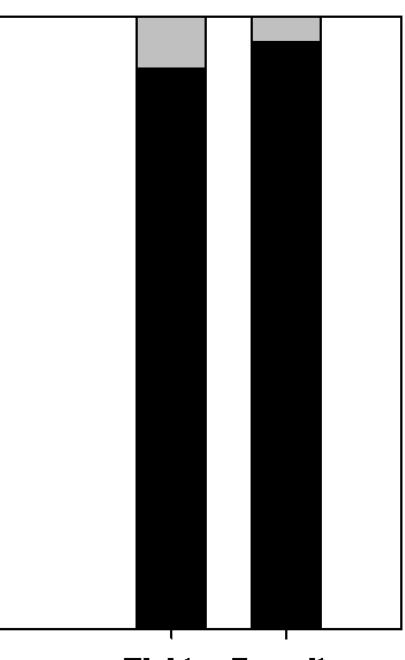

T5

Figure 4: Proportion of stunted plants caused by RSW infestation in two WOSR varieties in two consecutive years $\left({ }^{*}=\right.$ significant differences with $p<0.05$ between varieties within one date; $X^{2}$ - test)

The proportion of bent plant varied between the sampling dates. The sampling date T4 had more plants categorized in higher "bent" classes than at sampling date T5. At sampling date T4, only $12.5 \%$ and $18 \%$ of 'Elektra' and 'Favorite' plants respectively were not bent. The following sampling date T5 showed that, $50 \%$ of 'Elektra' and respectively $39 \%$ of 'Favorite' plants were not bent. Significant differences were not found ( $T 4 Z=0.43, p=0.67, T 5 Z=-1.59, p=0.11$ ). 


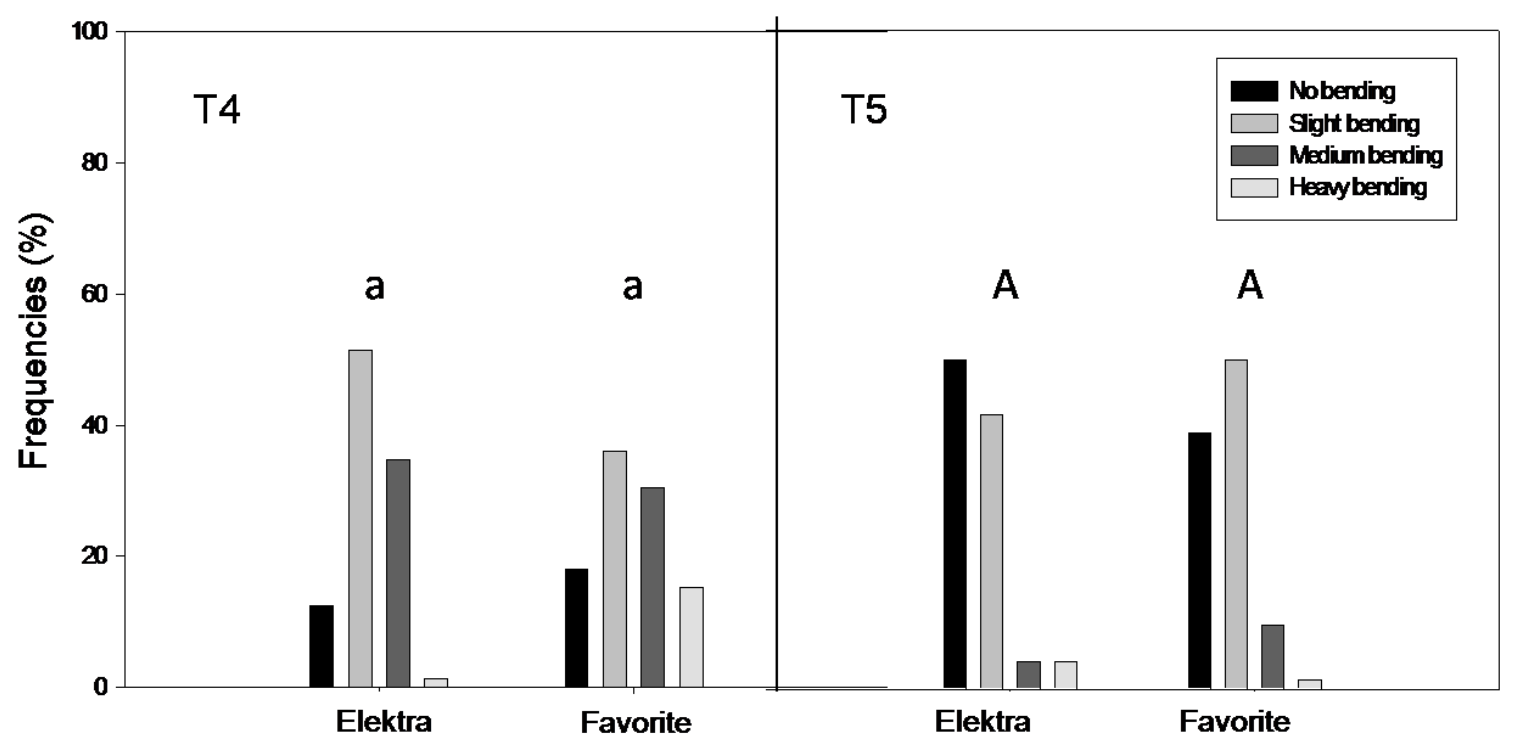

Figure 5: Frequencies of plants in different classes of the parameter value 'bending' in 2012 (different letters indicate significant differences with $p<0.05$ between plots within dates; Mann-Whitney U-test)

"Damage index" was significantly greater at sampling date T4 ( $F=0.00$, d.f. $=6, p<0.05)$ in 2012 for 'Favorite'. There was no significant difference at the next sampling date $T 5$, $(F=0.00$, d.f. $=6, p=$ 0.91). In the end, the "damage index" was almost the same in both varieties. 


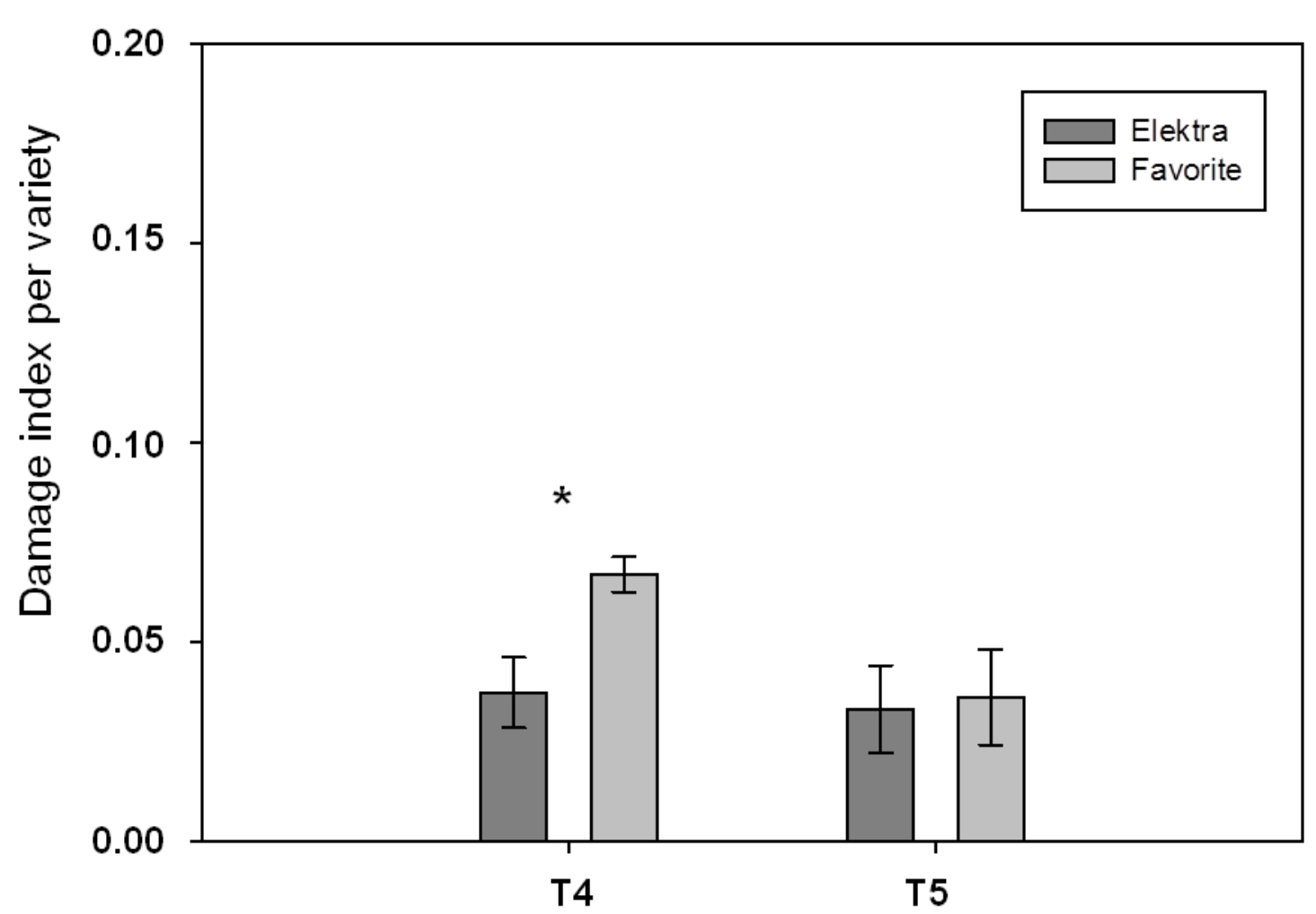

Figure 6: "Damage index" caused by RSW larvae in the varieties 'Elektra' and 'Favorite' in 2012 ( significant differences with $p<0.05$ between varieties within one date; One-way ANOVA, Tukey HSD)

\section{Beetle abundance and emigration}

Beetle abundance was recorded with yellow water traps. The catches started from $12^{\text {th }}$ of March until $2^{\text {nd }}$ of May in 2011 , when air temperature was above the threshold of $10^{\circ} \mathrm{C}$ air temperature for the first time. The highest beetle densities were recorded on the $22^{\text {nd }}$ of March 2011 with 271 beetles per trap. First beetle records in yellow water traps in 2012 were recorded on $2^{\text {nd }}$ of March. The main catches occurred on $16^{\text {th }}$ of March 2012 with a mean number of 1436 beetles per trap. After $17^{\text {th }}$ of April 2012, no more beetles were caught with the traps. 


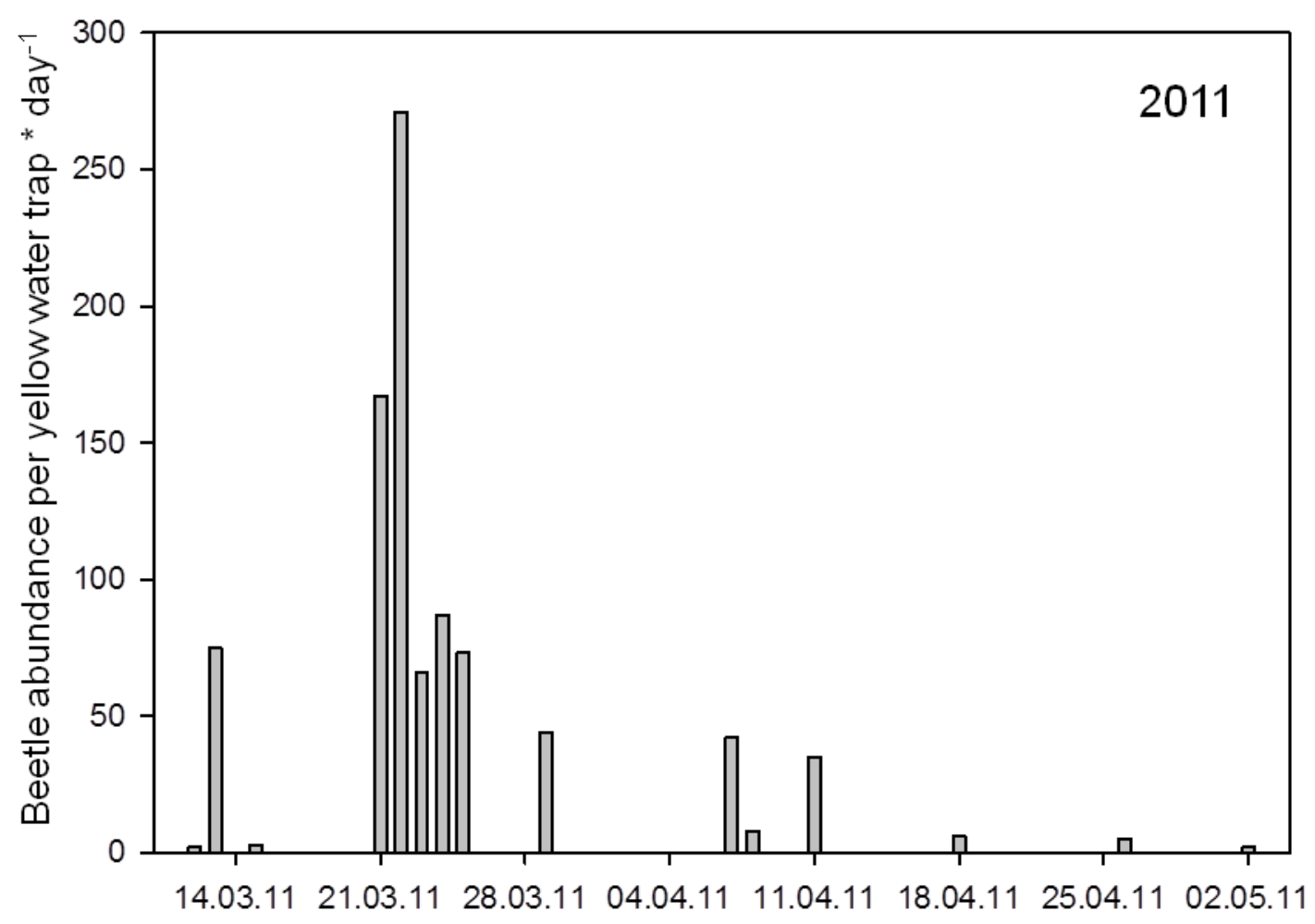

Figure 7: Beetle abundance per yellow water trap * day $^{-1}$ in the year 2011

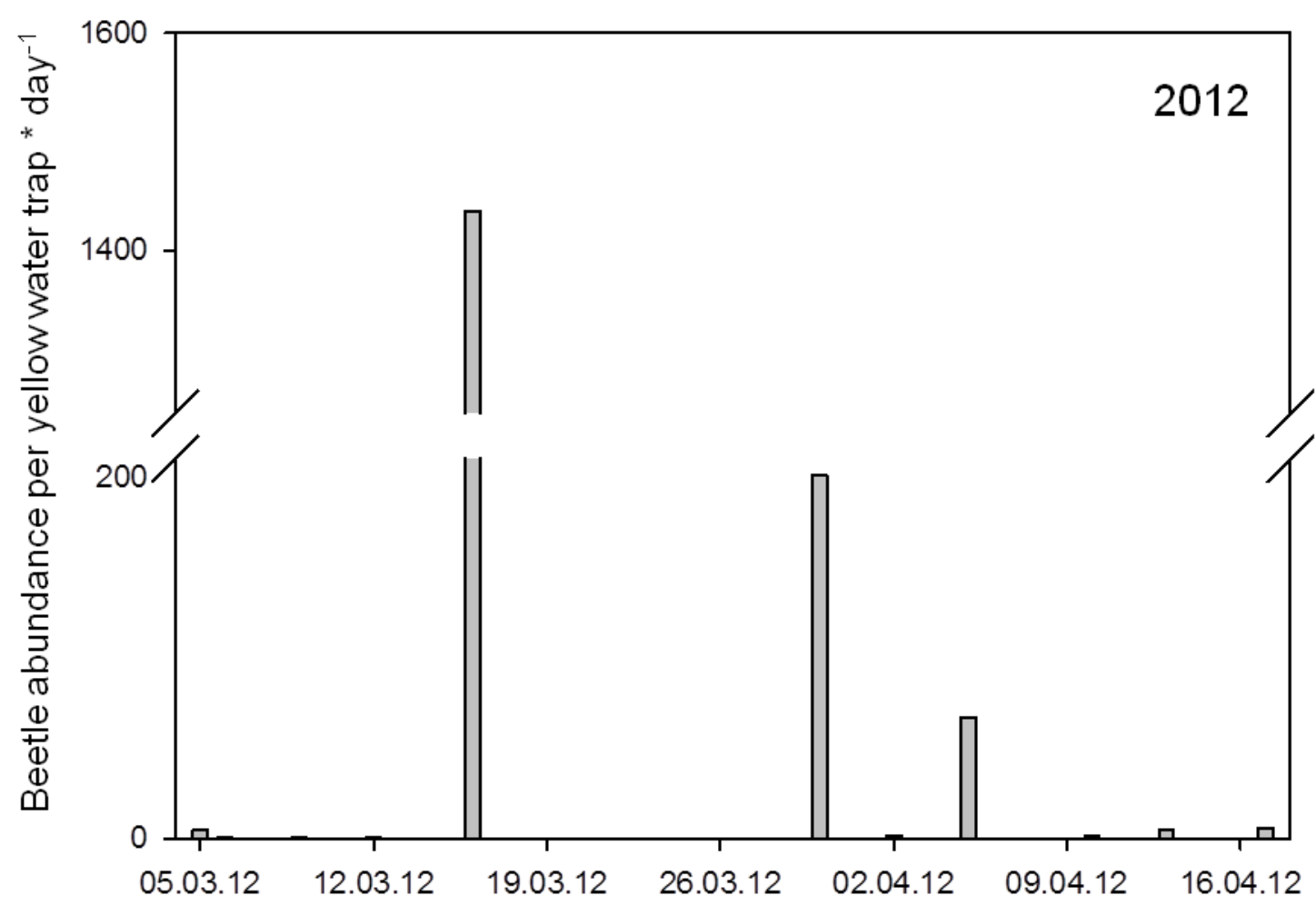

Figure 8: Beetle abundance per yellow water trap * day $^{-1}$ in the year 2012 
The emigration of larvae at the last larval stage was dependent on the sampling date. In both years, the major emigration occurred at the same date for both varieties. In 2011 and 2012, the number of larvae was significantly greater for 'Elektra' than for 'Favorite' (2011 $\mathrm{F}=11.07$, d.f. $=24, p<0.05$, $2012 \mathrm{~F}=2.17$, d.f. $=30, p<0.05)$. The mean number of emigrating larvae was more than double in the year 2011 with 10.2 larvae per plant for 'Favorite' and 24 larvae per plant for 'Elektra'. In 2012, 'Elektra' plants were infested with 7.2 emigrating larvae per plant, whereas 'Favorite' 11.2 larvae left per plant.

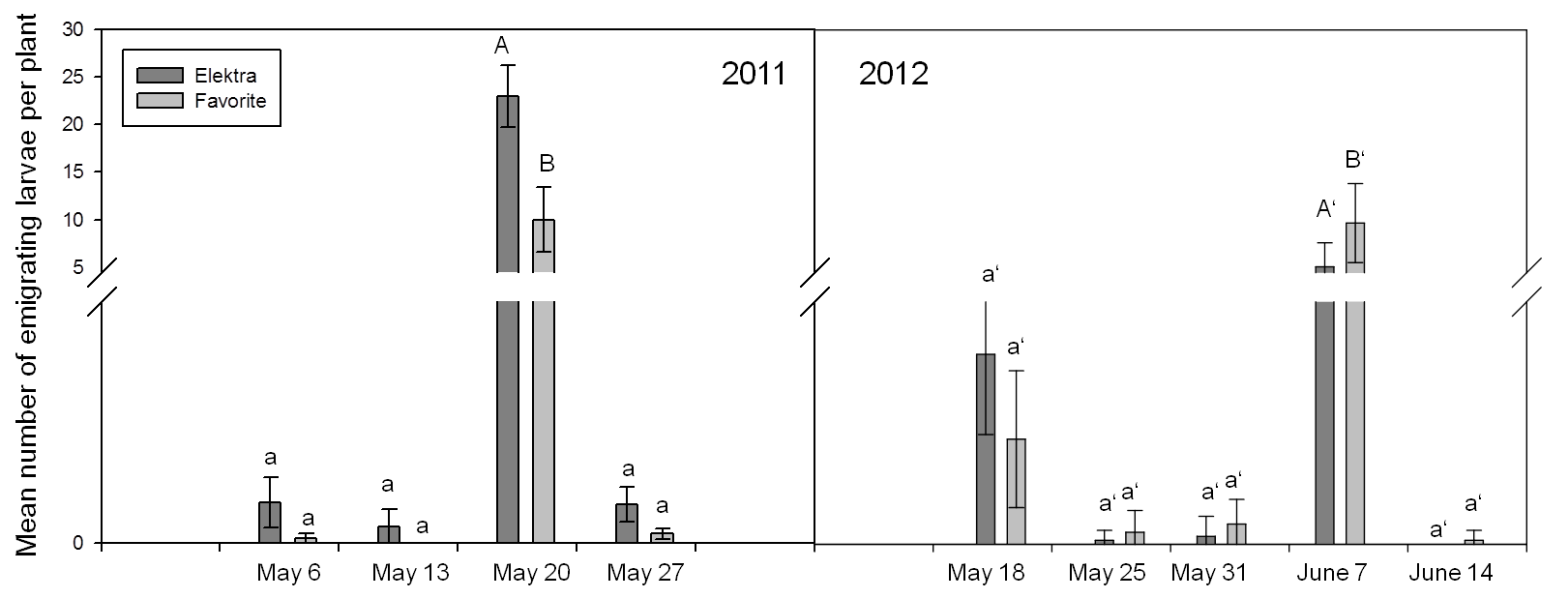

Figure 9: Mean number of emigrating larvae per plant in two WOSR varieties in two consecutive years, (letters indicate significant difference with $p<0.05$ between varieties and sampling dates, multiple ANOVA, Tukey HSD)

\section{Discussion}

Our study showed that there were differences in the phenology of different WOSR varieties, but they were not observed in springtime and did not last over the whole season. The RSW females preferred the well developed plants at the beginning of elongation until the late variety reached the same growth stage to be attractive for the females. The greater damage potential to the less developed variety 'Favorite' was not verified. Furthermore, there were no new parameters for the damage potential to be found. The previously introduced "stem injury index" was sufficient as reliable parameter. The emigration of the larvae occurred at the same date for both varieties. Therefore, the earlier infestation did not lead to an earlier emigration.

\section{Plant parameters}

Both varieties were affected by the harsh winter in 2012 in a similar way. Therefore, there were no differences in the plant density. This factor could, however, not influence the beetles in their oviposition behavior. Other studies concluded that there is a major role of growth stage development on host selection (Koubaiti and Lerin, 1992; Büchi, 1996; Rusch et al., 2013). The varieties in our field trial varied in their growth stages. The more advanced stages were favored for oviposition. This fact is also supported by the numbers of eggs laid in the main shoot for our trial. 'Elektra', as the earlier 
variety, had a higher number of eggs on the first sampling date. This is in common with other studies, where earlier development led to an earlier infestation (Koubaiti and Lerin, 1992). Later on, the abundance rose in the late variety 'Favorite'. The effect was already described, the earlier varieties were infested earlier, but later less developed varieties were preferred (Büchi, 1996). The change in oviposition between the varieties can be explained by the fact that RSW females are more attracted to a larger size of the host plant up to a length of $22 \mathrm{~cm}$ (Büchi, 1996). The varieties in our field trial also varied in the length of the main shoot. The early variety 'Elektra' grew rapidly over the $22 \mathrm{~cm}$ length. Therefore, our conclusion is that a prediction for the infestation should be more concerned with the stem length than the growth stage. The developmental stage after Lancashire et. al. (1991) cannot be used as a predictor for the length of the main stem. Whereas the growth stage only considers the appearance of certain plant parts (Lancashire et. al., 1991), there is no allowance for the length of the main stem. The same $\mathrm{BBCH}$ code can be given to plants with a wide range of stem lengths. Therefore, we would not include the $\mathrm{BBCH}$ code as a predictor for the RSW infestation.

The effect of advanced development did not last over the whole season. One reason could be that the varieties only differ slightly in their earlier development, but the time for harvest is similar within the same region. As the harvest date also depends on weather conditions and not just on the plant conditions (Diepenbrock, 2000), the plants had time to fulfill the same development.

\section{Plant-insect interaction}

As already noted, the dynamic for the oviposition was different for the two varieties in our trial. The early variety 'Elektra' was initially infested earlier, but as ovipositions in the later variety 'Favorite' increased later, no differences in the total number of eggs and larvae in the main stem were found at the end of the season. Also, other studies found no significant differences in the number of laid eggs between different varieties in open field trials (Koubaiti and Lerin, 1992; Büchi, 1996). In 2012, there were many sampling dates when no data for hatched larvae were recorded. With an almost linear correlation temperature is the strongest factor, for developmental rates (Bale et al., 2002; Thöming and Saucke, 2011), resulting in a delayed development of the eggs at low temperatures in spring 2012.

In terms of finding parameters which can predict the level of damage (Eickermann et al., 2011), several parameters were taken into account in our field trial. The stem injury coefficient is not a good indicator for damage when this parameter is taken constantly, as plants are still growing during the season. The stem injury is either more or less developed at the time the larvae hatch. This coefficient, therefore, stays constant or decreases. For that reason, this index is only a parameter for comparing different treatments like varieties within one sampling date, but not over time. The same can be said for the parameter "damage index". In addition to this, another factor needs to be considered. The more eggs that are laid in one stem, the more damage is given through the parameter of bursting stems (Büchi, 1996). Bursting stems are considered to happen more often at late frost events (Büchi, 1996). Therefore, the bursting of the stems and hence the "damage index" is more dependent on meotrological conditions than on the variety (Büchi, 1996). Other factors, like the parameters of stunting and bent plants, were not constant enough to succeed the prediction of the damage potential over time. For some reasons, these parameters improved over the sampling dates and it becomes apparent that these parameters are too weak to be reliable. 
In our experiment the varieties did not differ in terms of damage parameters. The hypothesis that the earlier RSW fly into the WOSR, the more damage can be caused in less developed plants, cannot be validated. WOSR, by itself, was considered to be more inhibited in its growth during springtime. Rapid warming in spring could cause an immigration of RSW adults at a time when WOSR has not yet started to grow. On the contrary, WOSR starts to regrow at a temperature of $5{ }^{\circ} \mathrm{C}$ in spring (Diepenbrock, 2000). Thus, a lack of synchronization is only to be expected on really rapidly warming events. The consequences of global climate change, global warming, (Eitzinger et al., 2010; IPCC, 2012) on the interaction between insects and their host plant are still unclear. Some researchers started models to predict the changes of insect behavior due to a changing climate (Gutierrez et al., 2008). The results lead towards earlier and prolonged immigrations of the insects by a few days per decade, but at the same time the host plant is more developed (Junk et al., 2012). Hence, there are no shifts in pest-host relationship. Similar models should be calculated for Ceutorhynchus napi (Junk et al., 2012).

\section{Beetles abundance and emigration}

The combination of lower insecticide use and the shorter distance to the former field could be an explanation for the high number per yellow water trap and the current population of RSW at the field side. In 2012, the abundance of adult RSW in the yellow water traps was so high, that effects of the WOSR variety were masked by the huge pest pressure, making it difficult to detect any differences. The field trial was located at a site of the university area with a permanent cultivation of WOSR and with no insecticide use for years. Therefore, the population could increase without any disturbance (Günthart, 1949). Additionally, there was a disagreement between the numbers of larvae found in the stems and in the number of emigrating larvae in 2011 and even greater in 2012. Different explanations could come into consideration. Some researchers found evidence for cannibalism within the stems (Lerin and Koubaiti, 1995). Another option could be an intraspecific competition for food, as there were too many larvae in one stem (Lerin and Koubaiti, 1995). Many more reasons can be held responsible for changes in the interaction between insects and their host plants. As agriculture is changing in terms of technologies, the use of growth regulators could lead to thicker pith (Alford, 2003) and likewise to a better food source for RSW. This leads to a better host selection as thin stems are avoided for oviposition (Dechert and Ulber, 2004). This may lead to higher pest densities in the stems. Other studies may interpret the results as an effect of landscape (Rusch et al., 2013), which is regarded to positively influencing the beetle abundance at our field site.

Nevertheless, the damage potential should mainly be considered, because the damage in early spring later leads to a reduced pod growth (Diepenbrock, 2000) and, therefore, to a reduced yield. The final number of pods is determined during the arrival time of RSWs. At this time, a continuous supply with assimilates is important for the maturing pods (Diepenbrock, 2000). If the assimilates have not been transported through the RSW damaged pith, the yield is at a risk. It has been previously recorded, that there are few studies addressing the impacts of climate change on crop yield whilst incorporating the effects of crop pests (Peterson et al., 2001; Gutierrez et al., 2008; Gregory et al., 2009). In summer 2012, the yield of both varieties was evaluated. The data is not shown in this study, because there was a high variation between the plots. Further investigation could also answer the link between pest infestation under climate change conditions and the value of the yield (Peterson et al., 2001). 
Otherwise, mathematical models could help to understand the impact of climate change in agro systems (Harte, 1995). Models could be useful as guides in future biological control efforts on existing and new exotic pest species (Gutierrez et al., 2008). In addition, the models can be a helping tool for farmers. Climate change will change agricultural practices (Weigel, 2005) and agriculture must adapt to a changing world (Eitzinger et al., 2010). Agricultural crops such as WOSR (Koubaiti and Lerin, 1992) have a good compensation capacity (Feeny, 1977) and, therefore, are able to deal with a new climate.

\section{Acknowledgement}

This work was financially supported by the Ministry for Science and Culture of Lower Saxony, Germany, within the research network "KLIFF- climate impact in Lower Saxony". 


\section{References}

Alford DV, Nilsson, C, Ulber, B, 2003. Insect pests of oilseed rape crops. In Alford, DV (Ed.) Biocontrol of oilseed rape pests. Blackwell Science, Oxford, UK, pp 9-41.

Bale JS, Masters GJ, Hodkinson ID, Awmack C, Bezemer TM, Brown VK, Butterfield J, Buse A, Coulson JC, Farrar J, Good J. E. G., Harrington R, Hartley S, Jones TH, Lindroth RL, Press MC, Symrnioudis I, Watt AD, Whittaker JB, 2002. Herbivory in global climate change research: direct effects of rising temperature on insect herbivores. GLOB CHANGE BIOL. DOI: 10.1046/j.13652486.2002.00451.x.

Bartlet E, 1996. Chemical Cues to Host-Plant Selection by Insect Pests of Oilseed Rape. Agricultural Zoology Reviews 7, 89-116.

Björkman M, Klingen I, Birch AN, Bones AM, Bruce TJ, Johansen TJ, Meadow R, Mølmann J, Seljåsen R, Smart LE, Stewart D, 2011. Phytochemicals of Brassicaceae in plant protection and human health - Influences of climate, environment and agronomic practice. Phytochemistry. DOI: 10.1016/j.phytochem.2011.01.014.

Büchi R, 1996. Eiablage des RapsstengelrüßlersCeutorhynchus napi Gyll., in Abhängigkeit der Stengellänge bei verschiedenen Rapssorten. ANZ SCHADLINGSKD PFL. DOI: 10.1007/BF01904715.

Cook SM, Rasmussen HB, Birkett MA, Murray DA, Pye BJ, Watts NP, Williams IH, 2007. Behavioural and chemical ecology underlying the success of turnip rape (Brassica rapa) trap crops in protecting oilseed rape (Brassica napus) from the pollen beetle (Meligethes aeneus). ARTHROPOD-PLANT INTE. DOI: 10.1007/s11829-007-9004-5.

Dechert G, Ulber B, 2004. Interactions between the stem-mining weevils Ceutorhynchus napi Gyll. and Ceutorhynchus pallidactylus (Marsh.) (Coleoptera: Curculionidae) in oilseed rape. AGR FOREST ENTOMOL. DOI: 10.1111/j.1461-9555.2004.00220.x.

Diepenbrock W, 2000. Yield analysis of winter oilseed rape (Brassica napus L.): a review. FIELD CROP RES. DOI: 10.1016/S0378-4290(00)00082-4.

Eickermann M, Ulber B, Vidal S, 2011. Resynthesized lines and cultivars of Brassica napus L. provide sources of resistance to the cabbage stem weevil (Ceutorhynchus pallidactylus (Mrsh.)). B ENTOMOL RES. DOI: $10.1017 / S 0007485310000489$.

Eitzinger J, Orlandini S, Stefanski R, Naylor REL, 2010. Climate change and agriculture: introductory editorial. J AGR SCI. DOI: 10.1017/s0021859610000481.

FAO, 2014. FAO 2014 [WWW document]. URL http://www.fao.org/home/en/.

Feeny P, 1977. Defensive Ecology of the Cruciferae. ANN MO BOT GARD 64, 221-234.

Gregory PJ, Johnson SN, Newton AC, Ingram JSI, 2009. Integrating pests and pathogens into the climate change/food security debate. J EXP BOT. DOI: 10.1093/jxb/erp080.

Günthart E, 1949. Beiträge zur Lebensweise und Bekämpfung von Ceuthorrhynchus quadriens PANZ. und Ceuthorrhynchus napi GYLL. mit Beobachtungen an weiteren Kohl- und Rapsschädlingen. Mitteilungen der Schweizerischen Entomologischen Gesellschaft 22, 441-591.

Gutierrez AP, Ponti L, d'Oultremont T, Ellis CK, 2008. Climate change effects on poikilotherm tritrophic interactions. CLIMATIC CHANGE. DOI: 10.1007/s10584-007-9379-4.

Häggström H, 1995. Slow larval growth on a suboptimal willow results in high predation mortality in the leaf beetle Galerucella lineola. OECOLOGIA 104, 308-315.

Harte J, 1995. Global Warming and Soil Microclimate: Results from a Meadow-Warming Experiment. ECOL APPL 5, 132-150. 
IPCC 2012, Managing the risks of extreme events and disasters to advance climate change adaptation. Cambridge University Press, New York.

Jalali MA, Tirry L, Clercq P, 2010. Effect of temperature on the functional response of Adalia bipunctata to Myzus persicae. BIOCONTROL. DOI: 10.1007/s10526-009-9237-6.

Johnen A, Williams I, Nilsson C, Klukowski Z, Luik A, Ulber B, 2010. The proPlant Decision Support System: Phenological Models for the Major Pests of Oilseed Rape and Their Key Parasitoids in Europe. In: Williams I (ed): Biocontrol-based integrated management of oilseed rape pests, Springer, Dordrecht; London, pp13-16

Junk J, Eickermann M, GÖRGEN K, Beyer M, Hoffmann L, 2012. Ensemble-based analysis of regional climate change effects on the cabbage stem weevil (Ceutorhynchus pallidactylus (Mrsh.)) in winter oilseed rape (Brassica napus L.). J AGR SCI. DOI: 10.1017/S0021859611000529.

Juran I, Gotlin Culjak T, Grubisic D, 2011. Rape Stem Weevil (Ceutorhynchus napi Gyll. 1837) and Cabbage Stem Weevil (Ceutorhynchus pallidactylus Marsh. 1802) (Coleoptera: Curculionidae) Important Oilseed Rape Pests. AGRICULTURAE CONSPECTUS SCIENTIFICUS 76, 93-100.

Köhler W, Schachtel GA, Voleske P, 2007. Biostatistik. [eine Einführung für Biologen und Agrarwissenschaftler] ; mit 50 Tabellen. 4th edition. Springer, Berlin, Heidelberg, New York.

Koubaiti K, Lerin J, 1992. Fecundity and egg laying dynamics of Baris coerulescens Scop. (Col., Curculionidae) on oilseed rape. J APPL ENTOMOL. DOI: 10.1111/j.1439-0418.1992.tb01129.x.

Lamb RJ, 1989. Entomology of Oilseed Brassica Crops. ANNU REV ENTOMOL. DOI: 10.1146/annurev.en.34.010189.001235.

Lerin J, Koubaiti K, 1995. Effect of temperature and plant size on the infestation dynamics of oilseed rape plants by Baris coerulescens Scop. (Col., Curculionidae) in field conditions. J APPL ENTOMOL. DOI: 10.1111/j.1439-0418.1995.tb01262.x.

Peterson RKD, Higley L, Peterson RKD, Higley LG, 2001. Biotic Stress and Yield Loss // Biotic stress and yield loss. CRC Press, Boca Raton, FL.

Rusch A, Valantin-Morison M, Sarthou J, Roger-Estrade J, 2013. Effect of crop management and landscape context on insect pest populations and crop damage. AGR ECOSYST ENVIRON. DOI: 10.1016/j.agee.2011.05.004.

Sander M, Andrén O, 1997. Ash from cereal and rape straw used for heat production: Liming effect and contents of plant nutrients and heavy metals. WATER AIR SOIL POLL. DOI:

10.1007/BF02404749.

StatSoft, Inc. (2011). STATISTICA for Windows Version 10.0

Thöming G, Saucke H, 2011. Key factors affecting the spring emergence of pea moth (Cydia nigricana). B ENTOMOL RES. DOI: 10.1017/S0007485309990642.

Tripathi MK, Mishra AS, 2007. Glucosinolates in animal nutrition: A review. ANIM FEED SCI TECH $132,1-27$.

Tuck G, Glendining MJ, Smith P, House JI, Wattenbach M, 2006. The potential distribution of bioenergy crops in Europe under present and future climate. BIOMASS BIOENERG. DOI: 10.1016/j.biombioe.2005.11.019.

Weigel HJ, 2005. Gesunde Pflanzen unter zukünftigem Klima. GESUNDE PFLANZ. DOI: 10.1007/s10343-004-0060-9.

Westwood AR, Blair D, 2010. Effect of regional climate warming on the phenology of butterflies in boreal forests in Manitoba, Canada. ENVIRON ENTOMOL. DOI: 10.1603/EN09143. 


\title{
Influence of climate change induced soil warming on oilseed rape - rape stem weevil interactions
}

\author{
A. REINHARDT ${ }^{1}$, B. ULBER ${ }^{1}$ and S. VIDAL ${ }^{1}$ \\ ${ }^{1}$ Georg-August University, Department of Crop Sciences, Agricultural Entomology, Grisebachstr. 6, \\ 37077 Goettingen, Germany, email: svidal@gwdg.de
}

\begin{abstract}
The influence of climate change on the oilseed rape and rape stem weevil interaction was investigated by induced soil warming in a semi-field trial. The measured parameters were based on plant characteristics and the damage potential through rape stem weevil oviposition and larval feeding. The adult emergence was studied with an artificial infestation using photoeclectors in the soil warming set up.
\end{abstract}

- The height of the main shoot was positively influenced by the increased temperature.

- The abundance of rape stem weevil larvae was higher in the heated plots.

- The damage of bent main stems caused by the oviposition of rape stem weevils was influenced by the soil temperature rather than by the oilseed rape variety.

- A higher emergence of adults in the plots with additional $2^{\circ} \mathrm{C}$ was measured

Keywords: Ceutorhynchus napi, Brassica napus, soil temperature, climate change, adult emergence

\section{Introduction}

There is little doubt that the global climate is changing, partly due to natural factors, but also human behavior (Eitzinger et al., 2010) as anthropogenic impact increases, greenhouse gases increasing the Earths' average surface temperature by 2 to $5^{\circ} \mathrm{C}$ during the next 50 to 100 years (Hansen, 1981). The main source of greenhouse gas is energy use, urbanization and land use changes (Karl, 2003). In case of climate change, the mean of temperature is shifting to a warmer range (Field, 2012). There are already studies reporting a significant temperature increase in the observed period (Westwood and Blair, 2010). There was an increase in the mean temperature by $0.05^{\circ} \mathrm{C}$ per year over 30 years in the Canadian forest (Westwood and Blair, 2010). For Lower Saxony, Germany, temperatures in the range of $+2^{\circ} \mathrm{C}$ for the near future and $+4^{\circ} \mathrm{C}$ for the far future are predicted by the regional climate model (REMO) (Endlicher and Gerstengarbe, 2007). The model REMO predicts a dominant effect on temperature during spring, winter, and autumn (Christensen and Christensen, 2007). Apart from this model, empirical information, about the dependence of biological criteria on climate parameters is lacking (Anderson, 1991).

Another important area of study is the altered impact of pests and diseases on crops in a changing climate (Eitzinger et al., 2010). Insects as ectotherms are sensitive to changes in their environmental temperature (Westwood and Blair, 2010; Bale et al., 2002). If temperature increases, we can expect insect herbivores and their interactions with host plants to be affected (Jalali et al., 2010).

This interaction is especially important for major crops such as oilseed rape (OSR), a major oil crop for Germany as the fourth biggest producer worldwide (FAO, 2013). OSR is attacked by various insect 
pests throughout plant development from seedling emergence to pod ripening (Bartlet, 1996; Alford et al. 2003). The Rape Stem Weevil (RSW) (Ceutorhynchus napi Gyll.)(Col.: Curculionidae) is one of the most devastating pests of winter oilseed rape (WOSR) (Brassica napus L.) throughout Central Europe. Adults emerge from former WOSR fields. First movement of RSW adults in the soil are recorded at 6 ${ }^{\circ} \mathrm{C}$ soil temperature (Günthart, 1949). They stay in lower soil layers until the air temperature reaches a $10^{\circ} \mathrm{C}$ threshold which triggers emergence from the soil and subsequent immigration into new WOSR fields (Günthart, 1949). A short maturation feeding begins before the females oviposit their eggs inside the stem (Johnen et al., 2010) which causes economic damage to the plant. Due to histological changes of the cortex, the pith exhibits porous cavities before the larvae hatch (Günthart, 1949). The infested stems can split open and have a bushy appearance through the development of more lateral shoots (Juran et al., 2011). The shoots appear bent, twisted or distorted (Juran et al., 2011). After larval hatching, the larvae feed on the stem pith until they reach the third and last instar. They bore out of the stem tissue and pupate within the top soil layers directly at the plant. The larvae build an earthen cocoon in which they pupate, until the adults leave it and move into bare soil in December followed by quiescence (Günthart, 1949).

The effect of increasing ambient temperatures on the start of RSW emergence and on interactions between plants and RSW has not been studied before. Only modeled data on related species exist (Junk et al., 2012). Based on these circumstances, we hypothesized that i) the soil temperature influences plant growth, ii) the oviposition of RSWs is affected by changes in plant growth, iii) the damage potential is modified with changes in soil temperature and iv) adults hatch earlier with increased soil temperature.

\section{Material \& Methods \\ Soil warming facility}

The influence of soil warming on OSR growth and RSW development was monitored in an experimental unit, described by Siebold and von Tiedemann (2012; Figure 1). The plots of this unit are located in Goettingen, Germany $\left(51.557953^{\circ} \mathrm{N}, 9.951894^{\circ} \mathrm{E}\right)$ and maintained with a power supply and a server for data transfer. The facility consists of 12 heatable plots arranged in two rows (Siebold and von Tiedemann 2012). Three temperature regimes, each replicated four times, were set up in a randomized block design. The regimes included control plots (ambient temperatures) as well as plots with temperature regimes with an increased mean soil temperature by $+1.6^{\circ} \mathrm{C}$ (near future) and by $+3.2^{\circ} \mathrm{C}$ (far future) during the whole OSR growing season. For simplicity these regimes are named $+2^{\circ} \mathrm{C}$ and $+4^{\circ} \mathrm{C}$ throughout the paper. Increased temperature levels were aligned to the warming scenarios for Lower Saxony for the near (2050) and far (2100) future, according to Endlicher and Gerstengarbe (2007). Heating coils were applied at a soil depth of $10 \mathrm{~cm}$ with $5 \mathrm{~cm}$ spacing between the coils. In each plot, eight temperature sensors (pT100, Steffen Messtechnik, Dorsten, Germany) were set up at a depth of $5 \mathrm{~cm}$ and $15 \mathrm{~cm}$ to adjust the temperatures to the fixed regimes and to allow the heated plots to adjust to the set points. Soil moisture was continuously registered by two sensors per plot (10HS FD, Decagon Devices, Inc. Pullman WA, USA). Each sensor recorded temperature and humidity levels at 5 minute intervals. The experimental site was enclosed by a rodent proof fence to prevent plants from wildlife grazing. 


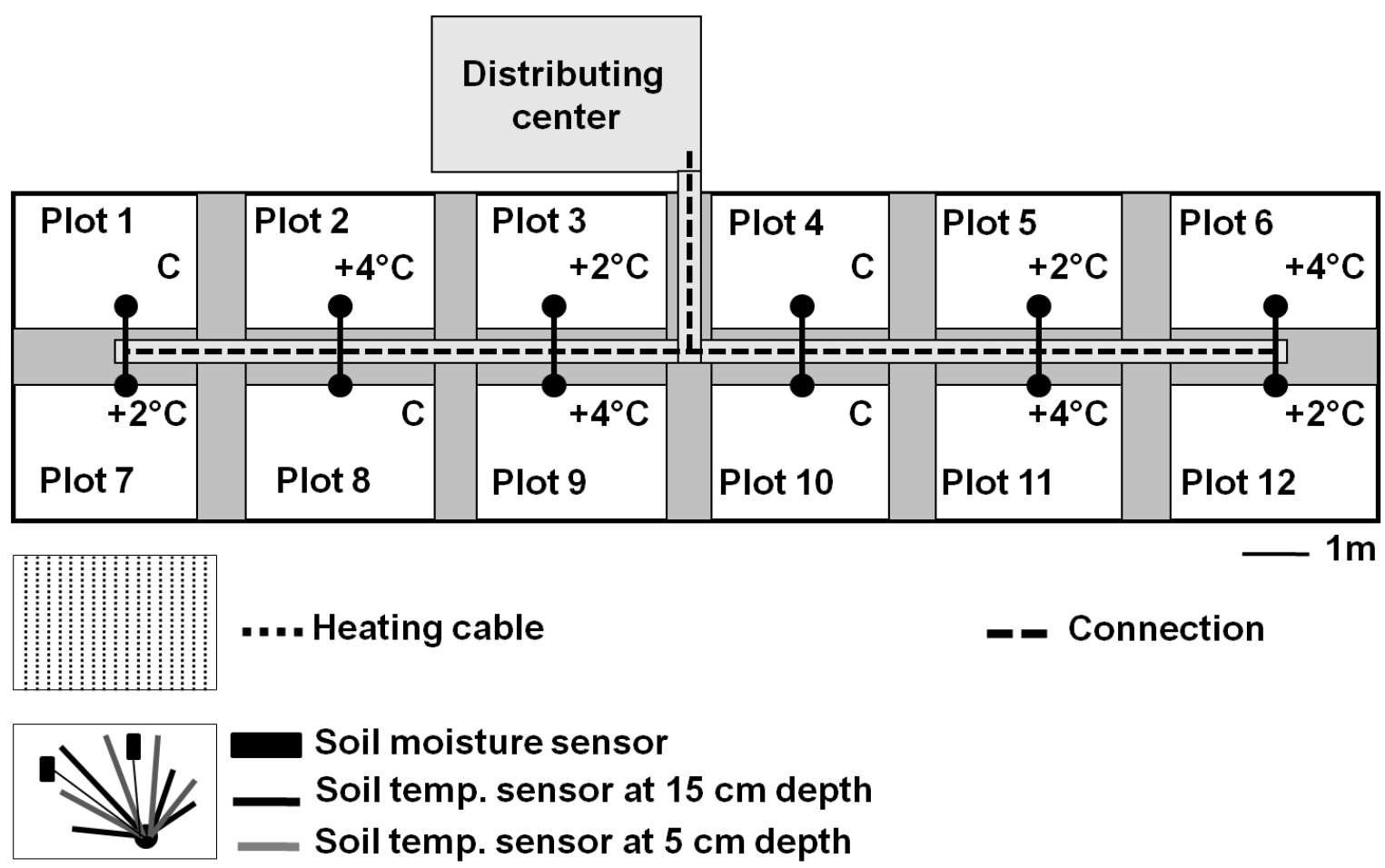

Figure 1. Experimental set up of soil warming facility, modified after Siebold and von Tiedemann (2012).

\section{Plant source}

Two OSR varieties differing in their susceptibility to fungal diseases were chosen (OSR cultivar 'Falcon' (NPZ Hohenlieth, Germany) and 'SEM 05-500256' (SW Seed, Stockholm, Sweden)). Both varieties are pooled in the analyses as to when the temperature regimes were compared and vice versa. The OSR varieties were sown by hand between the heating coils on the $25^{\text {th }}$ of August 2010 and $22^{\text {nd }}$ of August 2011 at sowing rates of 70 seeds per $\mathrm{m}^{2}$. Weekly observations were performed for assessing the sprouting, the growth of the plants and to quantify plant densities per plot.

\section{Rape stem weevil immigration and sampling}

During spring natural immigration and infestation of OSR plants by RSWs took place. Plants were harvested up to four weeks after the first record of natural RSW infestation. (Three sampling dates in 2011: $14^{\text {th }}$ of April, $5^{\text {th }}$ and $26^{\text {th }}$ of May; two sampling dates in 2012: $11^{\text {th }}$ of April and $8^{\text {th }}$ of May). In 2011 and 2012, 20 and 16 plants per plot, respectively, were randomly removed by cutting the stem 2 $\mathrm{cm}$ above the soil surface in 2011 and 16 plants per plot in 2012 were randomly cut at soil surface and transferred to the laboratory and dissected for larval density assessment and for measurements of plant parameters (growth stage (BBCH) according to Lancashire et al. (1991) and stem length (cm)). The number of eggs or larvae of RSW within the main stem were counted and the classification of bending of the main stem. Bending symptoms were categorizing the incidence of bending as none, light, medium, and heavy bending.

\section{Adult emergence Ceutorhynchus napi}

In 2012, an additional experiment was included to investigate the influence of temperature on the date of RSW infestation. A ground photoeclector with a diameter of $0.25 \mathrm{~m}^{2}$ was established in each plot on the $6^{\text {th }}$ of February 2012. $40 \mathrm{RSW}$ cocoons were buried at 5 to $10 \mathrm{~cm}$ soil depth within the eclector. The eclectors were closed with linen. Lightproof tent tops were placed on the eclectors on the $1^{\text {st }}$ of 
March 2012, when the soil temperature reached the $10^{\circ} \mathrm{C}$ threshold for adult hatching for the first time and immigration to the new OSR fields was expected to begin.

\section{Cocoon source}

RSW larvae at the $3^{\text {rd }}$ instar stage were extracted in May 2011 from infested oilseed rape stems from an open field. The larvae were transferred to boxes $(17.5 \mathrm{~cm} \times 13 \mathrm{~cm} \times 6 \mathrm{~cm}$, Neupack Verpackungen GmbH \& Co. KG, Hamburg, Germany) and placed on top of wet loamy soil, in which $90 \%$ of the larvae immediately buried themselves for pupation. Ten percent of the larvae remained on the soil surface and were removed. The boxes were maintained in a climate chamber at $20^{\circ} \mathrm{C}$ and $60 \%$ relative humidity in complete darkness. The temperature of the chamber was cooled down by $4{ }^{\circ} \mathrm{C}$ every second week until a $2^{\circ} \mathrm{C}$ temperature regime was reached. The boxes were left in the chamber until infestation in the trial. Cocoons were carefully sieved from the soil before infestation. 200 cocoons were opened before the experiment, to check for empty cocoons and parasitized larvae and calculate the potential RSW emergence rate.

\section{Statistical Analysis}

The data were analyzed with Statistica 10.0 (Tulsa, OK, USA) (2011). Years were analyzed separately. Significant differences were considered at a $p<0.05$.

The heights of the main stems were compared by a One-way ANOVA followed by a Tukey HSD (Honestly Significant Difference). A Kruskal-Wallis test was performed when the data were neither normally distributed nor a homogeneity of the variances was given. Bending symptoms were analyzed with a Mann-Whitney U-test. Adult emergence between the plots was analyzed by repeated measures ANOVA.

\section{Results}

\section{Temperature regimes in the soil warming facility}

The temperature between the plots was significantly different from each other $(F=0.11$, d.f. $=9, p<$ 0.05 ), except for the days from the $23^{\text {rd }}$ and $25^{\text {th }}$ of February $2012(F=0.03$, d.f. $=9, p=0.13$ ) and the time span between $28^{\text {th }}$ of April and $2^{\text {nd }}$ of May $2012(F=0.45$, d.f. $=9, p=0.15)$ (Fig. 2). In February the " $+2^{\circ} \mathrm{C}$ " and " $+4^{\circ} \mathrm{C}$ " plots were not significantly different. At the end of April, the plots with the ambient "control" temperature did not significantly differ compared to the heated " $+2^{\circ} \mathrm{C}$ " plots. 


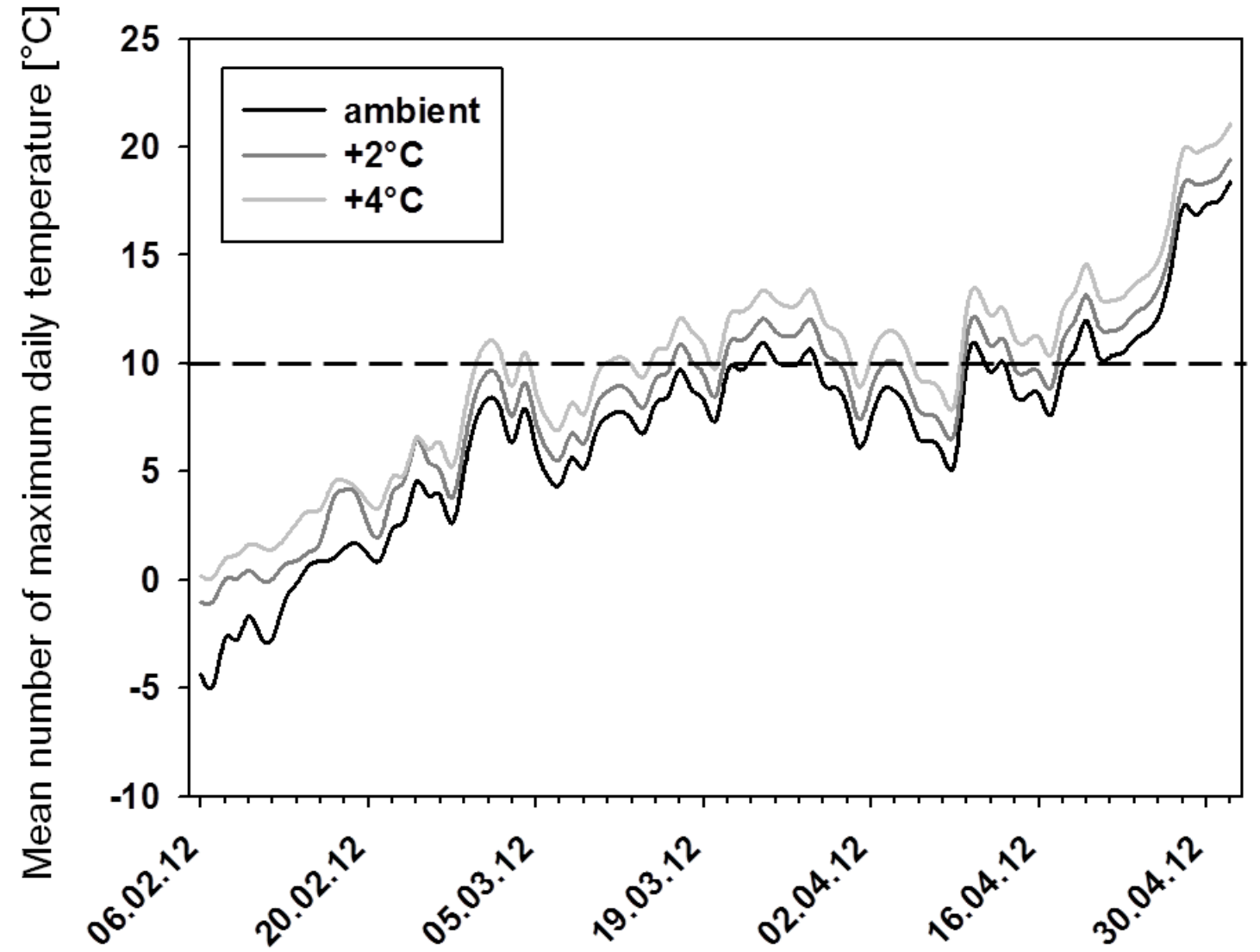

Figure 2. Mean maximum daily soil temperature in plots subjected to three temperature regimes. Temperature threshold of $10^{\circ} \mathrm{C}$ for emergence of RSW adult is indicated by a dotted line.

\section{Effects of soil warming on growth of Brassica napus plants}

Heating of the soil by $+2^{\circ} \mathrm{C}$ and $+4^{\circ} \mathrm{C}$ resulted in an enhanced growth of OSR plants. Compared to control plants, the plants in heated plots were significantly longer (Fig. 3). However, these significant differences were only recorded for the early sampling dates on the $14^{\text {th }}$ of April in 2011 and the $11^{\text {th }}$ of April in 2012 (2011: $\mathrm{H}=12.56, \mathrm{p}<0.05 ; 2012: \mathrm{F}=7.39$, d.f. $=45, \mathrm{p}<0.05$ ). During the season, the differences were not significant (2011: $F=183.85$, d.f. $=42, p=0.94$ and $F=153.82$, d.f. $=41, p=$ $0.98 ; 2012: F=120.85$, d.f. $=44, p=0.91$ ) 

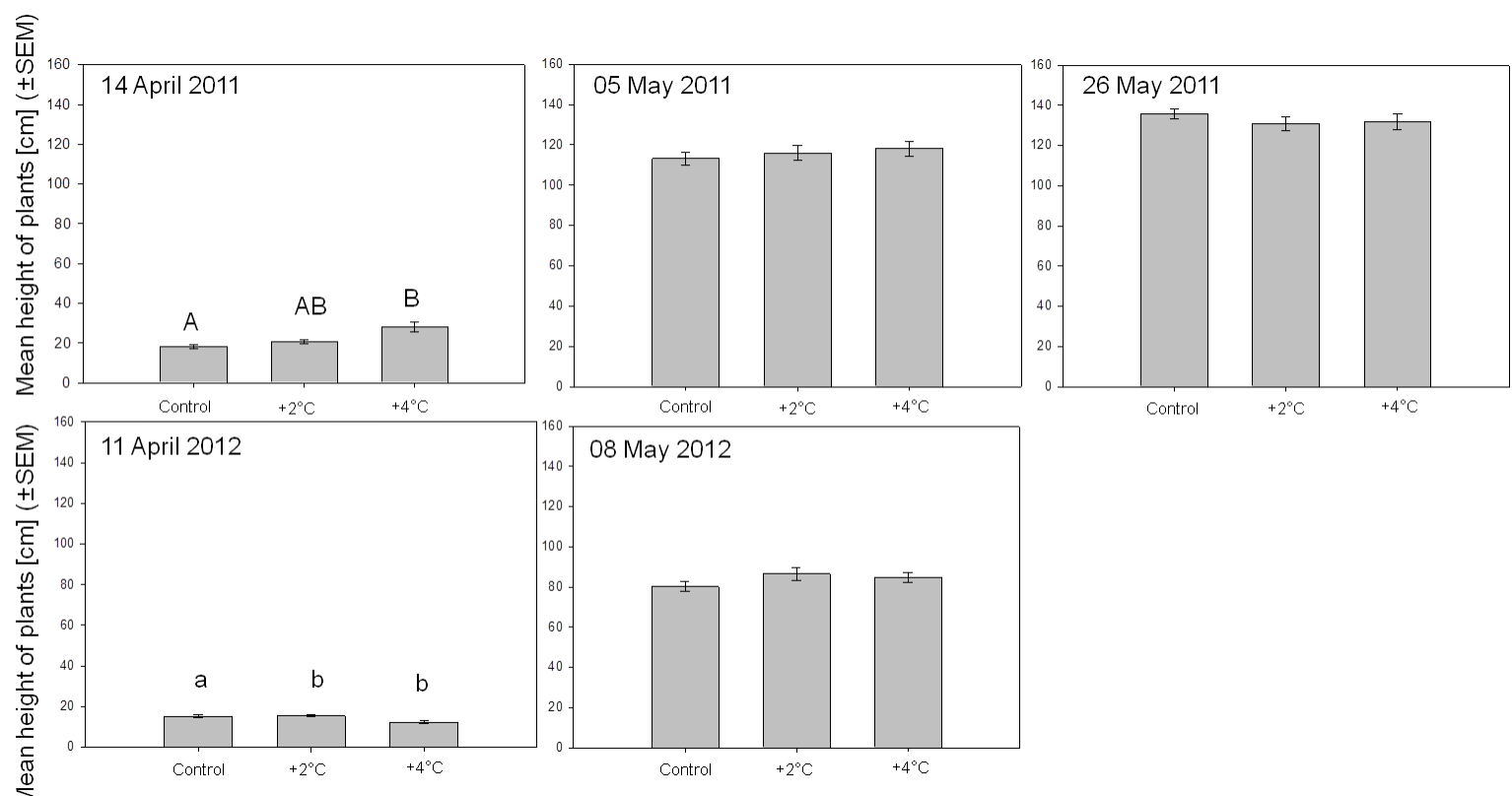

Figure 3. Plant height of OSR varieties at three different soil temperature levels in 2011 and 2012 (different letters indicate significant differences with $p<0.05$ between regimes)

\section{Effects of Brassica napus varieties on stem height}

The variety 'Falcon' was significantly longer than the variety 'SEM' at late sampling dates in May 2011 and 2012 (2011: $F=153.43$, d.f. $=42, p<0.05$ and $F=136.62$, d.f. $=42, p<0.05 ; 2012: F=101.39$, d.f. $=45, p<0.05)$.
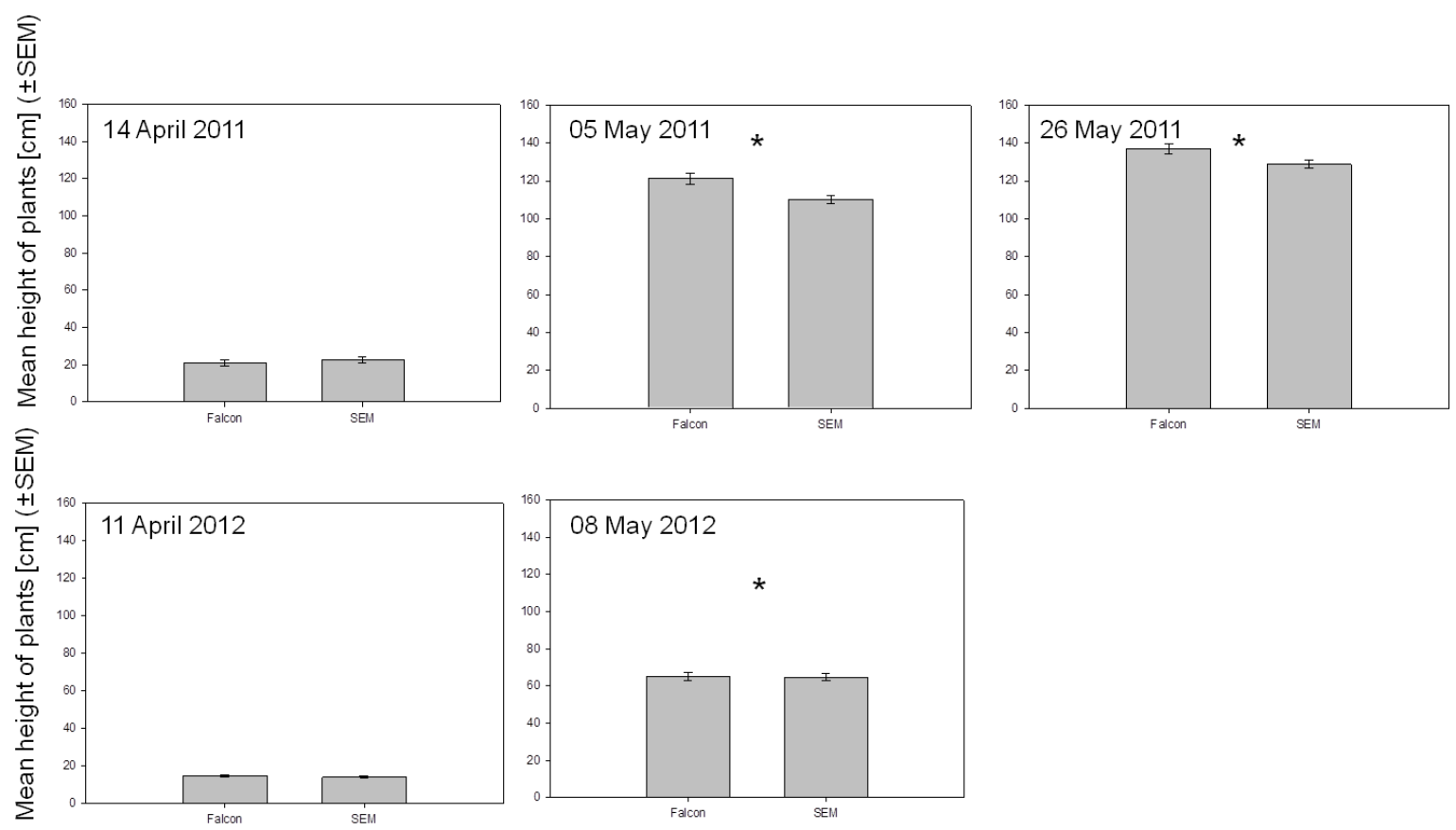

Figure 4. Plant height of two OSR varieties in 2011 and $2012\left({ }^{*}\right.$ indicate significant differences with $p<$ 0.05 between varieties) 


\section{Effects of soil warming on Brassica napus infestation by Ceutorhynchus napi}

Only 2 and 3 adults were caught in 2011 and 2012 in yellow water traps, respectively, throughout the whole growing season. Such a low density was not sufficient to explain the natural infestation of the OSR plants in the plots in relation to changes in soil temperature.

On the first sampling date $\left(14^{\text {th }}\right.$ April 2011), the number of eggs laid per plant did not significantly differ between the temperature regimes $(H=8.85, p=1.00)$. On the following sampling dates $\left(5^{\text {th }}\right.$ May and $26^{\text {th }}$ May 2011), the number of laid eggs was significantly higher in plants growing in the " $+2{ }^{\circ} \mathrm{C}$ " than in the " $+4^{\circ} \mathrm{C}$ " plots $(H=6.95, p<0.05 ; H=9.80, p<0.05)$.

On the first sampling date in 2012, the number of eggs laid per plant significantly differed between the heated, and the control plots with ambient temperature $(H=12.76, p<0.05)$. On the last sampling date, the larval density did not differ between the plots $(H=1.69, p=0.43)$.

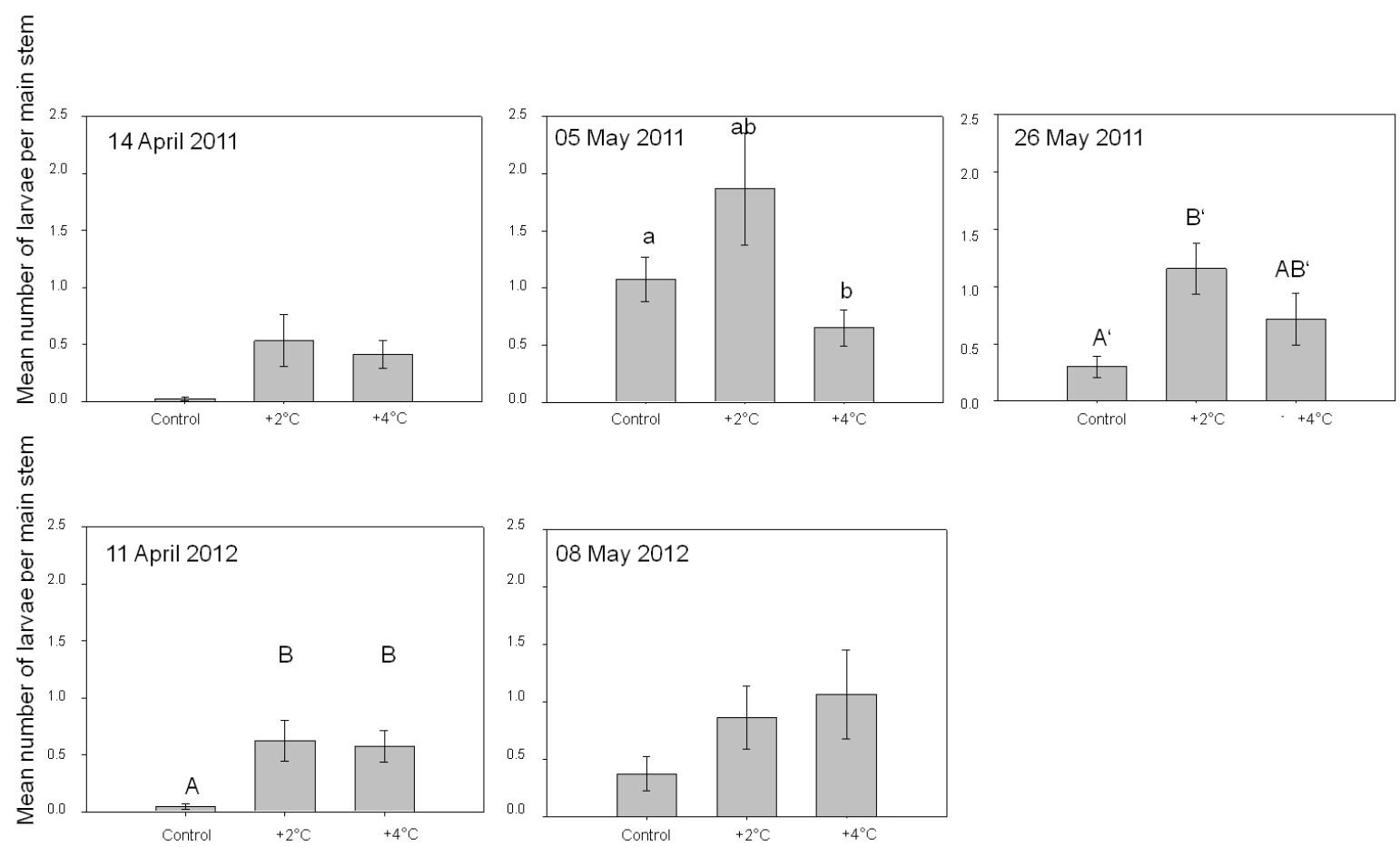

Figure 5. Mean number of extracted larvae per main shoot of OSR varieties at three different temperature levels at different sampling dates in 2011 and 2012 (different letters indicate significant differences with $p<0.05$ between varieties or temperature regimes)

\section{Effects of Brassica napus varieties on infestation by Ceutorhynchus napi}

Infestation of stems by RSW larvae was not affected by the OSR variety $(H=0.71, p=0.39 ; H=0.06$, $p=0.80$ ). On the last sampling date in 2011 , a significant difference in the number of larvae was measured $(H=3.94, p<0.05)$. The number of larvae decreased from the second sampling to the last sampling date. In 2012, no significant difference in the number of larvae per main shoot was measured at any sampling dates $(H=3.86, p=0.06 ; H=3.16, p=0.08)$. The number of larvae increased from the first sampling date to the last sampling date. 


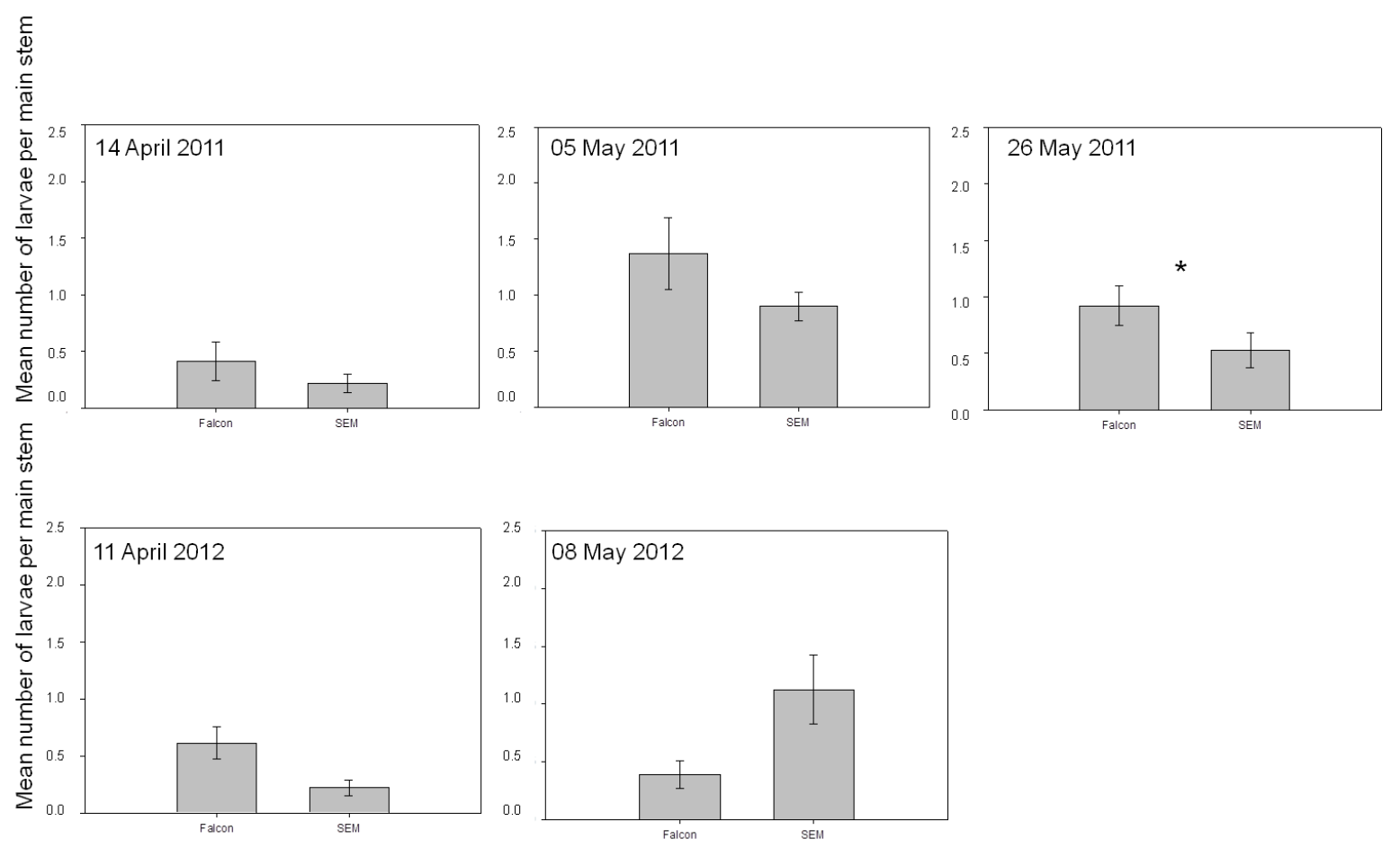

Figure 6. Mean number of extracted larvae per main shoot in two OSR at different sampling dates in 2011 and 2012 ( ${ }^{*}$ indicate significant differences with $p<0.05$ between varieties)

\section{Effects of soil warming on Brassica napus damage caused by Ceutorhynchus napi}

In 2012 different classifications of 'bending' in OSR plants were recorded. The "higher" bending classes occurred more often in the heated plots. On the first sampling date, the control plots were significantly less affected by this damage parameter (control $/+2^{\circ} \mathrm{C} Z=-1.99, p<0.05$; control $/+4^{\circ} \mathrm{C} \mathrm{Z}$ $=-1.95, p<0.05)$. The heated plots did not differ in the occurrence of the bending classifications $\left(+2^{\circ} \mathrm{C} /+4^{\circ} \mathrm{C} \mathrm{Z}=-0.15, p=0.88\right)$. The plants of the control plots were less bend than the plants from the heated plots (control $/+2^{\circ} \mathrm{C} Z=-3.12, p<0.05$; control $/+4^{\circ} \mathrm{C} Z=-1.98, p<0.05$ ). In comparison, the heated plots were not significantly different $\left(+2^{\circ} \mathrm{C} /+4^{\circ} \mathrm{C} Z=1.03, p=0.30\right)$. 

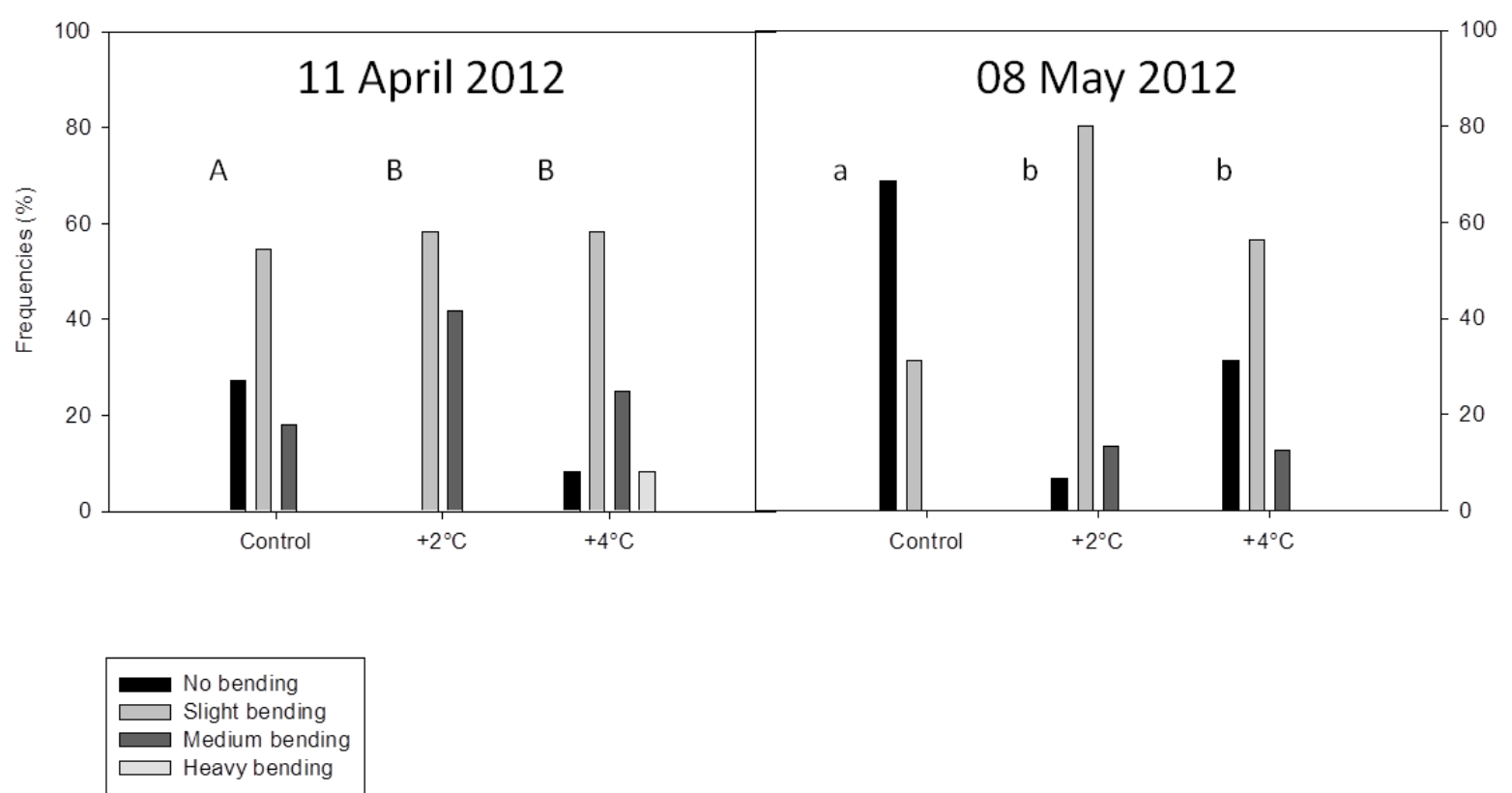

Figure 7. Frequencies of plants in different classes of the parameter value 'bending' at the sampling dates 11 April and 08 May 2012 (different letters indicate significant differences with $p<0.05$ between plots within sampling dates)

\section{Effects of varieties on Brassica napus plant damage by Ceutorhynchus napi}

The damage by RSW oviposition did not significantly vary between the tested varieties (Falcon/SEM Z $=-0.88, p=0.38 ;$ Falcon $/$ SEM $Z=0.15, p=0.88$.

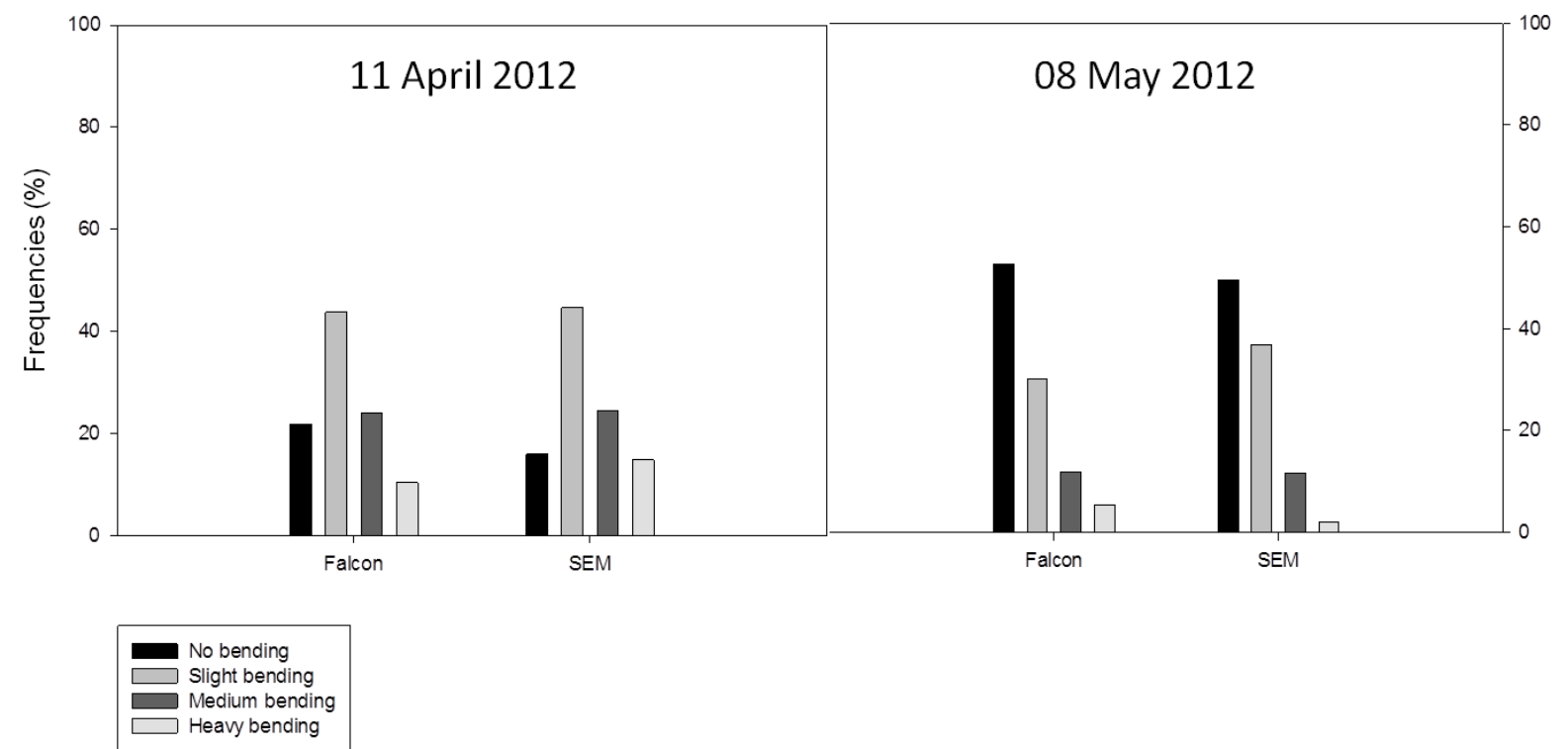

Figure 8. Frequencies of OSR varieties in different classes of the parameter value 'bending' at the sampling dates 11 April and 08 May 2012 (different letters indicate significant differences with $p<0.05$ between plots within sampling dates) 


\section{Effect of soil warming on adult emergence of Ceutorhynchus napi}

$19.17 \%$ of larvae in 200 tested cocoons were parasitized Tersilochus fulvipes Gravenhorst and 5.70\% were empty. Consequently, $75.13 \%$ of the opened cocoons could contain a viable RSW adult. Therefore, $30 \mathrm{RSW}$ adult weevils are expected to emerge from each eclector in the semi field plots. The mean number of weevils emerging from control, $+2^{\circ} \mathrm{C}$ and $+4^{\circ} \mathrm{C}$ plots was $18.5,24.2$ and 20.0 per eclector, respectively. The cumulative emergence curve differed between the three temperature scenarios (Figure 2). In plots heated to $+2^{\circ} \mathrm{C}$ and $+4^{\circ} \mathrm{C}, 50 \%$ of weevil emergence was already observed 14 days after the temperature threshold for emergence was reached and 13 days earlier than in unheated plots. There was only a one day difference between the plots heated to $+2^{\circ} \mathrm{C}$ and $+4^{\circ} \mathrm{C}$.

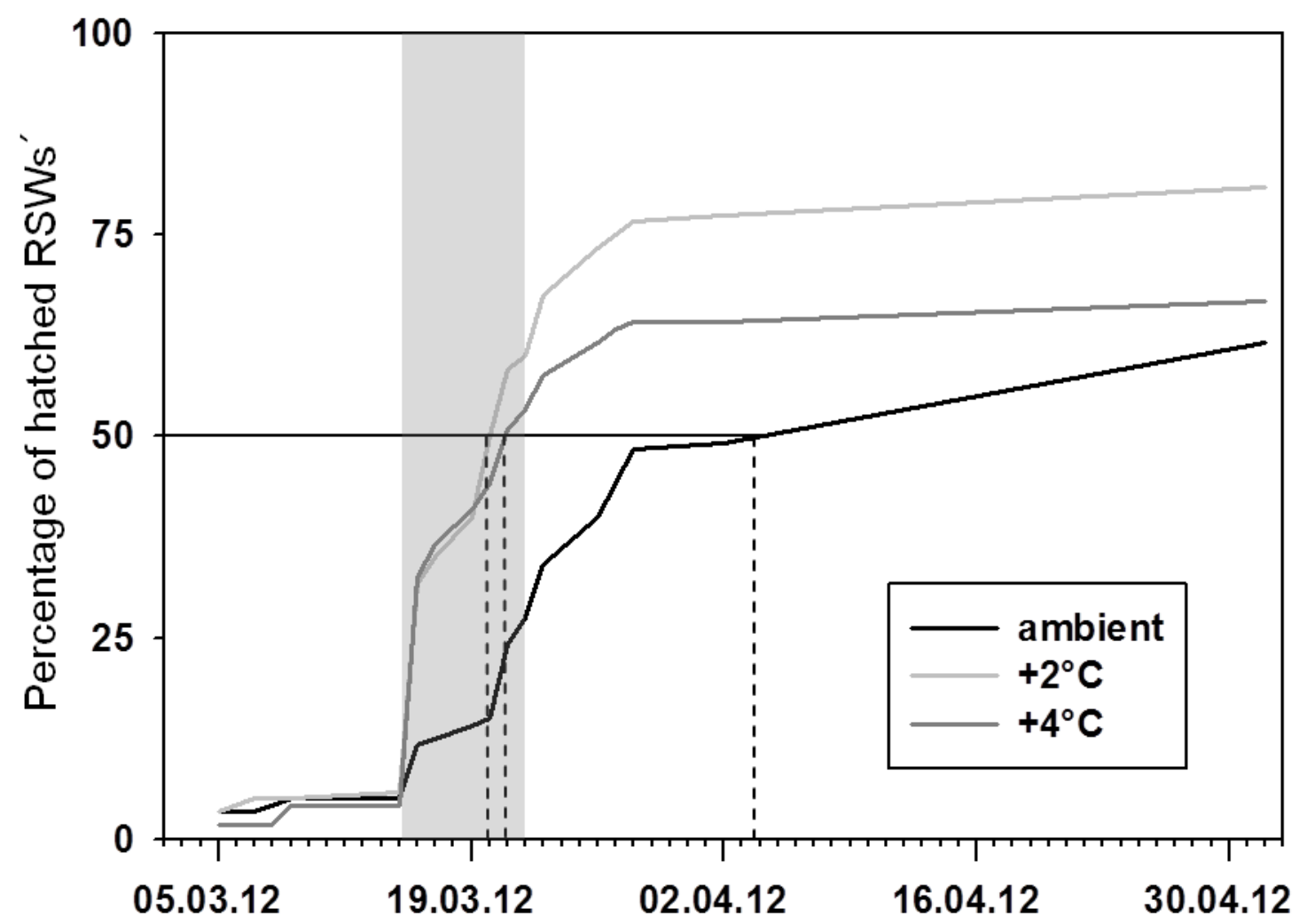

Figure 9. Cumulative percentages of hatched RSW adults per day at different temperature levels. Solid and dotted lines indicate the day at which $50 \%$ hatch occurred. Gray area highlights the time span which is express in detail by table 1 .

RSW adult emergence per day was significantly higher in heated plots than from plots with ambient temperature on the $16^{\text {th }}$ and $20^{\text {th }}$ of March $2012(F=8.42$, d.f. $=9, p<0.05, F=1.42$, d.f. $=9, p<$ $0.05)$ 
Table 1. Number of hatched RSW adults per treatment and date at different soil temperatures (mean number ( \pm SEM), repeated measures ANOVA)

\begin{tabular}{cccccccc}
\hline & 15.3 .12 & 16.3 .12 & 17.3 .12 & 19.3 .12 & 20.3 .12 & $\mathbf{2 1 . 3 . 1 2}$ & $\mathbf{2 2 . 3 . 1 2}$ \\
\hline Control & $0.0 \pm 0.00$ & $2.0 \pm 1.15 \mathrm{a}$ & $0.3 \pm 0.25$ & $0.5 \pm 0.29$ & $0.3 \pm 0.25 \mathrm{a}$ & $2.8 \pm 1.03$ & $1.0 \pm 0.71$ \\
$+2^{\circ} \mathrm{C}$ & $0.3 \pm 0.25$ & $7.8 \pm 1.65 \mathrm{~b}$ & $1.0 \pm 0.71$ & $1.5 \pm 0.50$ & $3.0 \pm 0.71 \mathrm{~b}$ & $2.5 \pm 0.50$ & $0.5 \pm 0.50$ \\
$+4^{\circ} \mathrm{C}$ & $0.0 \pm 0.00$ & $8.5 \pm 1.50^{\mathrm{b}}$ & $1.3 \pm 0.63$ & $1.3 \pm 0.25$ & $1.0 \pm 0.71^{\mathrm{ab}}$ & $2.0 \pm 1.35$ & $0.7 \pm 0.48$ \\
\hline
\end{tabular}

\section{Discussion}

Our study showed that an increase in soil temperature of $+2^{\circ} \mathrm{C}$ and $+4^{\circ} \mathrm{C}$ significantly affects WOSR plant growth, in early spring. Later during the growing season, the effect of the WOSR cultivar had a bigger influence on the stem height rather than changes in soil temperature. The RSW females preferred the heated plots compared to control plots for oviposition. The damage parameter 'bending' was more affected by plot temperature than WOSR variety. Additionally, adult emergence occurred two weeks earlier in heated plots compared to the control.

\section{Effects of soil warming on plant development of Brassica napus plants}

This study shows that plant height was positively influenced by the soil temperature in early spring. This would lead to the assumption that the crop duration on the field is shortened with increasing temperature. This adds further evidence to the consequences of climate change on crop growth as done in other studies such as Gregory et al. (2009) which predicts extended crop duration with increasing temperature.

\section{Effects of Brassica napus varieties on stem height}

Stem height was influenced by the tested WOSR cultivar rather than changes in soil temperature later in the growing season. Therefore, the synchronization of crop growth and pest occurrence may shift with climate change, which in turn provides new challenges for WOSR cultivation (Ferguson et al., 2003; Weigel, 2005), with new breeding goals for an output of new varieties.

\section{Effects of soil warming on Brassica napus infestation with Ceutorhynchus napi}

Although the yellow water traps did not record high numbers of RSWs, the infestation level was high enough to find significant differences in the larval infestation rate. The yellow water traps only give a poor picture of RSW population density and can only be used for detecting the first date of crop invasion (Debouzie and Ballanger, 1993). Despite the low beetle abundance in both years, the infestation was quite high regarding open field data. Without reaching the threshold in the yellow water traps (= ten RSWs in three days), the larval abundance was high enough to cause significant damage to the plants. A threshold for larvae which is correlated with the adult abundance is not yet known (Johnen et al., 2010).

A higher abundance of RSW larvae was recorded in the heated plots than in the control plots. In 2011, the number of larvae decreased on the last sampling date for the heated plot $+2^{\circ} \mathrm{C}$. This suggests that eggs laid earlier also lead to earlier larval emigration from the stem for pupation. Plants may have also 
not been an appropriate food source anymore, subsequently accelerating the time to pupation (Keena and Moore, 2010).

\section{Effects of Brassica napus varieties on infestation with Ceutorhynchus napi}

The oviposition of RSW is affected by plant growth as RSW females are attracted to stems up to 20 to $22 \mathrm{~cm}$ in length (Büchi, 1996). RSW oviposition and subsequent larval density per plant was therefore affected by the plot's soil temperature, rather than the WOSR cultivar, as changes in temperature regimes are the more dominant factor for increased stem height during the oviposition period. Over the past decades, temperatures have been increasing and this has led to earlier initiation of crop growth stages. Therefore, earlier laid eggs will be laid in more developed plants. Furthermore, the duration of growth stages for certain crops will be shortened (Eitzinger et al., 2010). Some previous studies have investigated the effects of temperature on insect herbivores and their interaction with plants (Dalin, 2011; Steinbauer, 2004). Experimental manipulation studies under field conditions are rare. Only a few studies address the impacts of climate change on the interaction between crops and their pests (e.g. Gregory et al., 2009) but could not come to a reliable conclusion for future predictions. This study shows that the effect of climate change to RSW will lead to an earlier infestation.

\section{Effect of soil warming and variety impact of Brassica napus damage caused by Ceutorhynchus} napi

The damage potential by RSW was more dependent on the soil temperature than on the WOSR variety. This result, however, may be confirmed by additional studies as there could be an effect of the larvae on the damage potential. On one hand, higher larval densities in the stem can lead to greater plant damage (Büchi, 1996), which may increase with climate change (Gutierrez et al., 2008); on the other hand, WOSR is known for its great compensation rate (Alford, 2003), which may lower any risks to enhanced damaged potential for climate change.

\section{Effect of soil warming on adult emergence of Ceutorhynchus napi}

Regardless of the insect, soil borne stages are not easy to study (Bento et al., 2010). Despite our initial hypothesis, an earlier hatch of adult RSWs in plots with " $+2^{\circ} \mathrm{C}$ " instead of the heated plots with " $+4^{\circ} \mathrm{C}$ " was observed. An additional " $4{ }^{\circ} \mathrm{C}$ " to the control temperature had a negative impact on RSW development in the buried cocoons, which shows that there is a more complex function behind the adult hatch than previously assumed. Earlier hatching dates have been described for other insect species during the last decades (Westwood and Blair, 2010). The climate change could result in an earlier flight of aphids within the UK by one month (Gregory et al., 2009). Also, there may be an earlier immigration into vineyards by the grape leafhopper Empoasca vitis in warm winters (Reineke and Hauck, 2012). With regard to WOSR pests, models predict an earlier adult crop invasion of the cabbage stem weevil (Junk et al., 2012).

The influence of temperature on population dynamics of insects is essential to insect-host interactions. Temperature is the single most important environmental factor affecting insect distribution, development, behavior, survival and reproduction (Bale et al., 2002). In addition, climate change will also influence other aspects of agro systems. Warmer winters could, for example, lower overwintering mortality of eggs, larvae, or pupae of butterflies (Westwood and Blair, 2010). In our study, RSW eggs are laid earlier due to earlier hatched adults, leading to an earlier larval emigration for pupation. These 
changes in insect development, however, are synchronized with plant growth as it will also adapt to warmer temperatures.

Other factors besides temperature have an impact on biological functions in an insect-host interaction under natural conditions. The soil type is more important for hatch of dipterous females, whereas dipterous males are rather influenced by soil type and humidity level (Bento et al., 2010). As climate change is a gradual process, it has been predicted that pests and their biological control agents will synchronize with the host plant (Gerard et al., 2013). Under drought stress, pathogens can have reduced (Gregory et al., 2009) or higher impact (Siebold and von Tiedemann 2013) on crops. The impacts of pests and diseases on yield under current conditions are well known, but the consequences of climate change on pests and diseases are complex and are still only poorly understood (Gregory et al., 2009). Nevertheless, agriculture must adapt to a changing climate (Weigel, 2005). This experiment helped to understand parts of these complex interactions with an interaction between an WOSR pest and its host mediated via increased soil temperature.

\section{Conclusion}

Strong warming has been measured in the period from 1971 to 2004 (Westwood and Blair, 2010). Significant warming has occurred at various monthly sequences, resulting in a significant increase in the annual mean temperature (Westwood and Blair, 2010), resolving any doubts for global climate change. This will change the human's interest on earth, especially in agricultural plant production (Weigel, 2005). Farmers' choices are influenced by the uncertain conditions for growing a crop. Therefore, the crops produced in a region will change as growers will optimize their economic returns in the prevailing climate and markets (Gerard et al., 2013).

Each organism will be affected differently by climate change, creating a very complex picture for future scenarios (Gutierrez et al., 2008). Therefore, caution should be taken when extrapolating results from greenhouse experiments on insect-plant relations to natural situations (Stinner et al., 1974). An important issue when considering adaptation and mitigation responses to climate change is the uncertainty in the prediction of the future climate (Christensen and Christensen, 2007). Models could be useful as guides in future biological control efforts on existing and new exotic pest species (Gutierrez et al., 2008). To generate more evidence for predicting biological processes based on models, research must be done on indicators for soil humidity for example to predict adult hatch (Thöming and Saucke, 2011) or including the length of tibia as a good indicator of body size, which is usually correlated with fitness (Le Lann et al., 2011).

\section{Acknowledgement}

This work was financially supported by the Ministry for Science and Culture of Lower Saxony, Germany, within the research network "KLIFF- climate impact in Lower Saxony". 


\section{References}

Alford DV, Nilsson, C, Ulber, B, 2003. Insect pests of oilseed rape crops. In Alford, DV (Ed.) Biocontrol of oilseed rape pests. Blackwell Science, Oxford, UK, pp 9-41.

Anderson, J.M., 1991. The effects of climate change on decomposition processes in grassland and coniferous forests'. ECOL APPL 1, 326-347.

Bale, J.S., Masters, G.J., Hodkinson, I.D., Awmack, C., Bezemer, T.M., Brown, V.K., Butterfield, J., Buse, A., Coulson, J.C., Farrar, J., Good J. E. G., Harrington, R., Hartley, S., Jones, T.H., Lindroth, R.L., Press, M.C., Symrnioudis, I., Watt, A.D., Whittaker, J.B., 2002. Herbivory in global climate change research: direct effects of rising temperature on insect herbivores. GLOB CHANGE BIOL 8, 116.

Bartlet, E., 1996. Chemical Cues to Host-Plant Selection by Insect Pests of Oilseed Rape. Agricultural Zoology Reviews 7, 89-116.

Bento, F.M.M. de, Marques, R.N., Costa, M., Walder, J., Silva, A.P., Parra, J., 2010. Pupal Development of Ceratitis capitata (Diptera: Tephritidae) and Diachasmimorpha longicaudata (Hymenoptera: Braconidae) at Different Moisture Values in Four Soil Types. ENVIRON ENTOMOL 39, 1315-1322.

Büchi, R., 1996. Eiablage des Rapsstängelrüsslers, Ceutorhynchus napi Gyll. In Abhängigkeit von der Stengellänge bei verschiedenen Rapssorten. ANZ SCHADLINGSKD PFL 69, 136-139.

Christensen, J.H., Christensen, O.B., 2007. A summary of the PRUDENCE model projections of changes in European climate by the end of this century. CLIMATIC CHANGE 81 (S1), 7-30.

Dalin, P., 2011. Diapause induction and termination in a commonly univoltine leaf beetle (Phratora vulgatissima). INSECT SCI 18 (4), 443-450.

Debouzie, D., Ballanger, Y., 1993. Dynamics of a Ceutorhynchus napi population in winter rape fields. ACTA OECOL 14 (5), 603-618.

Eitzinger, J., Orlandini, S., Stefanski, R., Naylor, R.E.L., 2010. Climate change and agriculture: introductory editorial. J AGR SCI 148 (05), 499-500.

Endlicher, W., \& Gerstengarbe, F. W. 2007. Der Klimawandel. Einblicke, Rückblicke und Ausblicke. Potsdam-Institut für Klimafolgenforschung, Potsdam.

FAO, 2013. FAO 2012. http://faostat3.fao.org/home/index.htmI\#VISUALIZE_TOP_20. Accessed 10 July 2013.

Ferguson, A. W., Klukowski, Z., Walczak, B., Clark, S. J., Mugglestone, M. A., Perry, J. N., \& Williams, I. H. 2003. Spatial distribution of pest insects in oilseed rape: implications for integrated pest management. AGR ECOSYST ENVIRON 95(2), 509-521.

Field, C.B., 2012. Managing the risks of extreme events and disasters to advance climate change adaption. Cambridge University Press, New York, 582 pp.

Gerard, P.J., Barringer, J.R.F., Charles, J.G., Fowler, S.V., Kean, J.M., Phillips, C.B., Tait, A.B., Walker, G.P., 2013. Potential effects of climate change on biological control systems: case studies from New Zealand. BIOCONTROL 58 (2), 149-162.

Gregory, P.J., Johnson, S.N., Newton, A.C., Ingram, J.S.I., 2009. Integrating pests and pathogens into the climate change/food security debate. J EXP BOT 60 (10), 2827-2838.

Günthart, E., 1949. Beiträge zur Lebensweise und Bekämpfung von Ceuthorrhynchus quadriens PANZ. und Ceuthorrhynchus napi GYLL. mit Beobachtungen an weiteren Kohl- und Rapsschädlingen. Mitteilungen der Schweizerischen Enotmologischen Gesellschaft 22 (5), 441-591. 
Gutierrez, A.P., Ponti, L., d'Oultremont, T., Ellis, C.K., 2008. Climate change effects on poikilotherm tritrophic interactions. CLIMATIC CHANGE 87 (S1), 167-192.

Hansen, J.D., 1981. Climate Impact of Increasing Atmospheric Carbon Dioxide. SCIENCE 213 (4511), 957-966.

Jalali, M.A., Tirry, L., Clercq, P., 2010. Effect of temperature on the functional response of Adalia bipunctata to Myzus persicae. BIOCONTROL 55, 261-269.

Johnen, A., Williams, I., Nilsson, C., Klukowski, Z., Luik, A., Ulber, B., 2010. The proPlant Decision Support System: Phenological Models for the Major Pests of Oilseed Rape and Their Key Parasitoids in Europe, in: , Biocontrol-Based Integrated Management of Oilseed Rape Pests // Biocontrol-based integrated management of oilseed rape pests. Springer, Dordrecht ;, London.

Junk, J., Eickermann, M., GÖRGEN, K., Beyer, M., Hoffmann, L., 2012. Ensemble-based analysis of regional climate change effects on the cabbage stem weevil (Ceutorhynchus pallidactylus (Mrsh.)) in winter oilseed rape (Brassica napus L.). J AGR SCI 150 (02), 191-202.

Karl, T.R., 2003. Modern Global Climate Change. SCIENCE 302 (5651), 1719-1723.

Keena, M.A., Moore, P.M., 2010. Effects of Temperature on Anoplophora glabripennis. ENVIRON ENTOMOL 39 (4), 1323-1335.

Lancashire, P. D.; Bleiholder, H.; van Boom, T. Den; Langelüddeke, P.; Stauss, R.; Weber, E.; Witzenberger, A. (1991): A uniform decimal code for growth stages of crops and weeds. In: Ann Applied Biology 119, S. 561-601.

Le Lann, C., Wardziak, T., van Baaren, J., van Alphen, J.J.M., 2011. Thermal plasticity of metabolic rates linked to life-history traits and foraging behaviour in a parasitic wasp. FUNCT ECOL 25, 641651.

Reineke, A., Hauck, M., 2012. Larval development of Empoasca vitis and Edwardsiana rosae (Homoptera: Cicadellidae) at different temperatures on grapevine leaves. J APPL ENTOMOL 136, 656-664.

Siebold, M., Tiedemann, A. von, 2012. Application of a robust experimental method to study soil warming effects on oilseed rape. AGR FOREST METEOROL 164, 20-28.

Siebold, M., Tiedemann, A. von, 2013. Effects of experimental warming on fungal disease progress in oilseed rape. GLOB CHANGE BIOL 19(6), 1736-1747.

StatSoft, Inc. (2011). STATISTICA for Windows (Software system for data analyse), Version 10.0. www.statsoft.com.

Steinbauer, M.J., 2004. Modelling a forest lepidopteran: phenological plasticity determines voltinism which influences population dynamics. FOREST ECOL MANAG 198 (1-3), 117-131.

Stinner, R.E., Gutierrez, A.P., Butler Jr., G.D., 1974. An algorithm for temperature-dependent growth rate simlation. CAN ENTOMOL 106 (5), 519-524.

Thöming, G., Saucke, H., 2011. Key factors affecting the spring emergence of pea moth (Cydia nigricana). B ENTOMOL RES 101, 127-133.

Weigel, H.J., 2005. Gesunde Pflanzen unter zukünftigem Klima. GESUNDE PFLANZ 57, 6-17.

Westwood, A.R., Blair, D., 2010. Effect of regional climate warming on the phenology of butterflies in boreal forests in Manitoba, Canada. ENVIRON ENTOMOL 39 (4), 1122-1133. 


\title{
Impact of climate change on the fertility of the rape stem weevil (Ceutorhynchus napi Gyll.)
}

\author{
A. Reinhardt ${ }^{1}$, B. Ulber ${ }^{1}$ and S. Vidal ${ }^{1}$ \\ ${ }^{1}$ Georg-August University, Department of Crop Sciences, Agricultural Entomology, Grisebachstr. 6, \\ 37077 Goettingen, Germany, email: svidal@gwdg.de
}

\begin{abstract}
1. Oviposition and longevity of adult rape stem weevils was tested under different temperature regimes. Three average daily temperatures were assessed at constant and varying regimes.

2. Females laid more eggs with increasing temperature. In contrast to constant regimes, the varying temperature regimes resulted in more laid eggs.

3. The longevity of adult rape stem weevils was not influenced by the different constant temperature regimes.

4. No egg hatched at the constant temperature regime of $8^{\circ} \mathrm{C}$, whereas at the varying temperature regime with the same average daily temperature same eggs were able to hatch.

5. The developmental time for eggs was significantly the longest at $10 / 6^{\circ} \mathrm{C}$.

6. The mortality rate of eggs was increased by constant temperature in contrast to the varying equivalent.
\end{abstract}

Keywords: Longevity, egg development, varying temperature regimes, fecundity

\section{Introduction}

Insects are poikilotherms and their internal temperature depends on the environmental temperature (Davidson, 1944). Some researchers even expect that there is no difference between the body temperature of insects and air temperature (Taylor, 1963; Higley et al., 1986). The temperature plays a major role in their development (Gilbert and Raworth, 1996) and many studies regard this relationship to be linear (Gilbert and Raworth, 1996; Satar et al., 2005). A rise in temperature speeds up insect development until the optimal temperature is exceeded and developmental speed declines (Higley et al., 1986; Sandhu et al., 2010). Therefore, the model of day-degrees was used to predict insect development (Pruess, 1983). The model is calculated assuming that a certain developmental stage is completed at a certain sum of temperature degrees, which are accumulated over a certain threshold per day (Pruess, 1983). These calculations are mostly assumptions made on trials with constant temperature regimes upon which many studies are based on (Baffoe et al., 2012). The zero point of day-degree data is only a calculated threshold by fitting a linear regression equation, which is highly related to the acceptation that enzyme kinetics is the driving factor for development (Higley et al., 1986). If varying temperature regimes are given, day-degree models are not able to predict the developmental stages (Stinner et al., 1974; Wilstermann and Vidal, 2013), which is however important for forecasting population dynamics in natural habitats. With varying temperature regimes, the daydegree models only give a rough estimate of the developmental time (Higley et al., 1986). 
Developmental times were elongated at constant low temperature and significantly shortened at constant high temperatures than at fluctuating temperatures with the same means. At medium temperatures, developmental times were adapted (Hagstrum and Milliken, 1991). In nature the constant temperatures are not applicable to insects (Stinner et al., 1974; Satar et al., 2005). To draw conclusions on the effects of increasing temperature on pest populations in the field, varying temperature regimes have to be included in laboratory studies (Hagstrum and Hagstrum, 1970; Hagstrum and Leach, 1973; Stinner et al., 1974; Wilstermann and Vidal, 2013).

The oviposition of insects can be influenced by haptic (Marazzi and Städler, 2004) or chemical cues (Mewis et al., 2002; Marazzi et al., 2004) from the host plant. Furthermore, host phenology (Rusch et al., 2013) is important as well as their nutrient status (Veromann, 2013). Egg laying by females is mostly influenced by ambient temperatures. There are many studies showing that the temperature directly influences the oviposition of females. These studies were representing different species such as beetles (Keena and Moore, 2010), crickets (Behrens et al., 1983), aphids (Gutierrez et al., 2008), planthoppers (Wang et al., 2013), flies and moths (Davidson, 1944).

For an effective pest management, the interactions between insects and their host plant need to be considered (Pruess, 1983). The rape stem weevil (RSW) (Ceutorhynchus napi Gyll.) is the first pest to feed on crops of winter oilseed rape (WOSR) (Brassica napus L.) in early spring in Germany. After a few days of feeding on WOSR leaves, RSW females lay their eggs into the stem close to the terminal bud during stem elongation (Günthart, 1949). Injuries caused by adult feeding are not significant (Juran et al., 2011). The main damage is caused by egg-laying females which results in a histological change of the stem pith (Alford et al, 2003). Damage appears as distorted stems (Günthart, 1949) with high yield losses (Büchi, 1996). Beside the phenology of the plant (Büchi, 1996), the temperature plays an important role for oviposition (Debouzie and Ballanger, 1993; Juran et al., 2011). The damage on some developmental stages can only be observed with a large effort as the larval hatch of RSWs happens well protected inside the stems of WOSR plants. This makes it difficult to observe development in the field and makes it necessary to introduce a new method to this research field.

The focus of this study was the effect of temperature on fertility, embryonic development and adult longevity of RSW. In the first experiment, we tested the number of eggs laid, the longevity, the survival rate and the duration of egg deposition of RSW females at different constant temperature regimes. In the second experiment, we hypothesized that constant and varying temperature regimes, each with the same daily average, would change the pattern of egg hatch of RSWs. We assumed that eggs under varying temperature regimes require less developmental time than under constant temperature regimes.

\section{Materials \& Methods \\ Rape Stem Weevils and plant source}

The trial was set up using fifteen replicates at three different temperature regimes in climate cabinets (MytronWB 750 KFL, Mytron Bio- und Solartechnik GmbH, Germany). Adult RSWs used in this experiment were collected from overwintering fields and new crops of WOSR during the main flight period in March by using empty yellow water traps (Syngenta Agro $\mathrm{GmbH}$, Maintal, Germany). Adults were picked up immediately after landing in the traps and transferred to plastic boxes 
(17.5cm * $13 \mathrm{~cm}$ * $6 \mathrm{~cm}$, Neupack Verpackungen GmbH \& Co. KG, Hamburg, Germany). They were supplied with leaves of WOSR as food and a dry paper tissue (Tork Universal, SCA Hygiene Products AFH Sales $\mathrm{GmbH}$, Mannheim, Germany) to absorb condensation. Groups of 20 - 50 weevils were stored in boxes in a climate chamber at a constant temperature of $14^{\circ} \mathrm{C}$ to ensure ovary maturation and mating process. Boxes and leaves were changed weekly to prevent contamination by pathogens. Prior to the start of the experiments, beetles were segregated by their sex under a stereomicroscope (Leica Wild M3Z, Leica Microsystems GmbH, Wetzlar, Germany) with a 40x magnification.

The test plants were cultivated in the greenhouse. Seeds of the spring oilseed rape variety 'Mozart' were sown in mixed soil substrate, composed by three parts of potting soil (Fruhstorfer Erde (Typ 25), Hawita Gruppe $\mathrm{GmbH}$, Vechta, Germany) and one part sand. After emergence, plants were singly transplanted in 9-cm-diameter pots using the same mixed soil substrate. Plants were watered daily and fertilized once a week with a $2 \%$ Hakaphos solution (Compo, Muenster, Germany). After 5 to 6 weeks, at a stem height of $15 \mathrm{~cm}$, plants were used for the oviposition experiments.

\section{Egg deposition at different temperatures regimes}

To mimic common ambient temperature regimes during spring and early summer in the region of Goettingen, Germany $\left(51.557953^{\circ} \mathrm{N}, 9.951894^{\circ} \mathrm{E}\right)$, climate cabinets, in the first experiment, were kept at constant temperatures of 8,11 and $14^{\circ} \mathrm{C}$, respectively, $(\mathrm{RH} 85 \%$; photoperiod 12:12 L:D, fluorescent tube type: Master TL-D 18W/840, Royal Philips Electronics, Amsterdam, Netherlands). Females of $C$. napi were released on the fifteen plants by using gauze cages $(20 \mathrm{~cm}$ high, $9 \mathrm{~cm}$ diameter, mesh size $0.02 \mathrm{~mm}$ ) fastened to the top $10 \mathrm{~cm}$ of the stems. Basal leaves were removed to prevent to fit into the cage. In 2011, two female RSWs were added to each cage and were assumed to be fertilized by males during the time they were kept in the boxes. In 2012, a modification was made to varying day-night temperature regimes with the same average daily temperature as in the experiment using constant temperatures. To achieve the mean temperature of 8,11 and $14^{\circ} \mathrm{C}$, respectively, the following day/night temperatures were set for $12 \mathrm{~h}$ each: $10 / 6^{\circ} \mathrm{C}, 13 / 9^{\circ} \mathrm{C}$ and $16 / 12^{\circ} \mathrm{C}$. A 24 hour pretest verified that each female was able to lay eggs. One female was caged on one plant. Each plant was checked after 24 hours for eggs. Plants in 2011 were swapped in regular intervals and dissected for the number of eggs laid by females every 24 hours in the first week and then weekly until July. After July, the changes of the stems were done every second week. In 2012, the plants were exchanged daily.

\section{Performance of adult weevils at different temperature regimes}

The weevils in the 2011 trial were maintained from April until the last female died in December. The survival rate was calculated as the mean number of surviving females at each temperature. The longevity was calculated as the mean number of days of females alive. Fertility was evaluated as the mean number of days until the last egg was laid.

\section{Egg development}

To study the effect of temperature on the duration of the embryonic development, the eggs were exposed to constant and varying temperature regimes of 8,11 and $14^{\circ} \mathrm{C}$ mean temperature until hatching. Fifteen plants with elongated stems of $15 \mathrm{~cm}$ were offered to gravid RSW females for egg deposition at each temperature regime. After 24 hours, the eggs were collected from these plants by dissection of stems under a stereomicroscope. These eggs were transferred to 6 -cm-diameter petri 
dishes with a wet filter paper (MN 616, Macherey-Nagel GmbH \& Co. KG, Dueren, Germany) to prevent desiccation. Dishes were sealed with Parafilm (Parafilm M, Pechiney Plastic Packaging, Chicago, USA) to prevent any fungal or bacterial contamination after relocation from the stem. The sample size varied by the females $\left(8^{\circ} \mathrm{C} n=38,10 / 6^{\circ} \mathrm{C} n=64,11^{\circ} \mathrm{C} n=38,13 / 9^{\circ} \mathrm{C} n=63,14^{\circ} \mathrm{C} n=37\right.$ and $\left.16 / 12^{\circ} \mathrm{C} n=64\right)$. The dishes were incubated in climate cabinets with the same temperature at which the eggs were laid. Petri dishes were checked daily for egg hatch. A $15 \times$ magnification was used to separate visible head capsule within the egg shells from those head capsules of already hatched larvae. Hatched larvae were counted and the period of embryonic development was calculated by the time span from egg deposition to hatch. Egg mortality was calculated by the percentage of non-hatched larvae in relation to the total number of all eggs.

Data loggers (DL-120 TH USB Humidity/Temperature Logger, Voltcraft, Hirschau, Germany) were set up in each climate cabinet to record relative air humidity, temperature and dew point.

\section{Data analysis and statistics}

A repeated measures ANOVA was used to identify differences in the mean number of laid eggs per sample time for the constant temperature regimes. Differences between mean number of laid eggs, longevity, reproduction time and developmental time of RSW eggs were tested with a Kruskal Wallis test. If significant differences were found between these parameters, a non-parametric multiple comparison test was used to test significant differences between temperature regimes and temperature levels for mean number of laid eggs, fertility, longevity and developmental time of eggs. Differences in the mortality rates of RSW eggs in petri dishes were assessed by using a $X^{2}$-test.

\section{Results}

\section{Egg deposition at different temperatures regimes}

The number of eggs laid by RSW females significantly increased with increasing constant mean temperature regime $(F=4.47$, d.f. $=14, p<0.05)$.

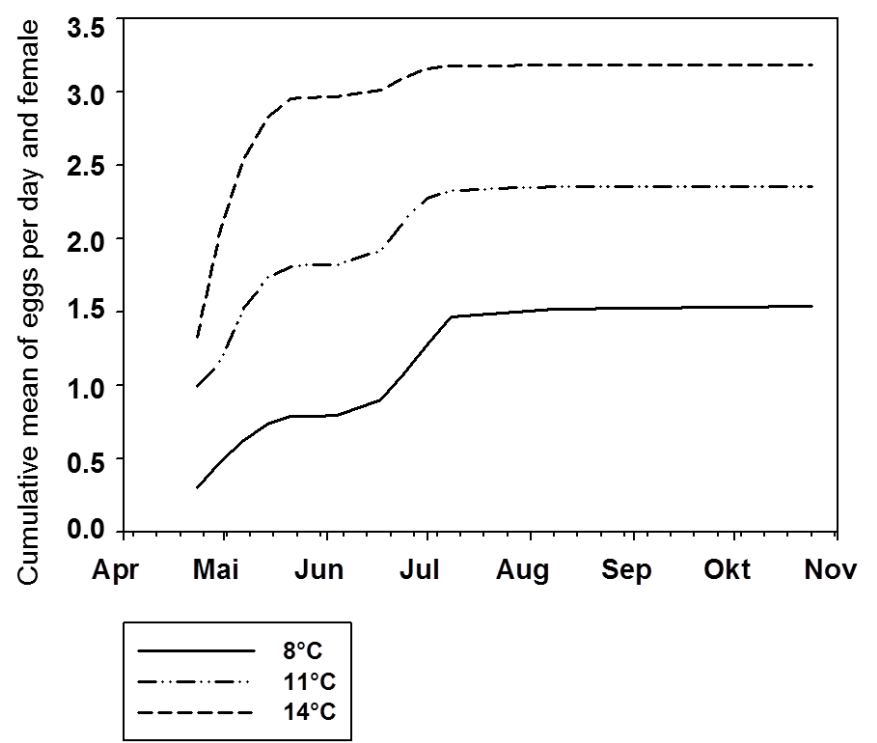

Figure 1: Cumulative mean number of eggs per day and female laid between April and October for the constant temperature regimes (repeated measures ANOVA, $F=4.47$, d.f. $=14, p<0.05$ ) 
When comparing the egg deposition at the mean temperature of $8^{\circ} \mathrm{C}$ and at the varying temperature regime $10 / 6^{\circ} \mathrm{C}$, egg numbers at varying temperature increased almost threefold $(H=4.65, p<0.05)$. With regard to the medium temperature regimes, egg numbers at the varying temperature regime of $13 / 9^{\circ} \mathrm{C}$ significantly increased 2.5 -fold compared to the constant temperature of $11^{\circ} \mathrm{C}(\mathrm{H}=4.74, \mathrm{p}<$ 0.05). Egg numbers at the highest varying temperature regime of $16 / 12^{\circ} \mathrm{C}$ increased two-fold compared to the constant temperature regimes of $14^{\circ} \mathrm{C}(\mathrm{H}=8.55, \mathrm{p}<0.05)$.

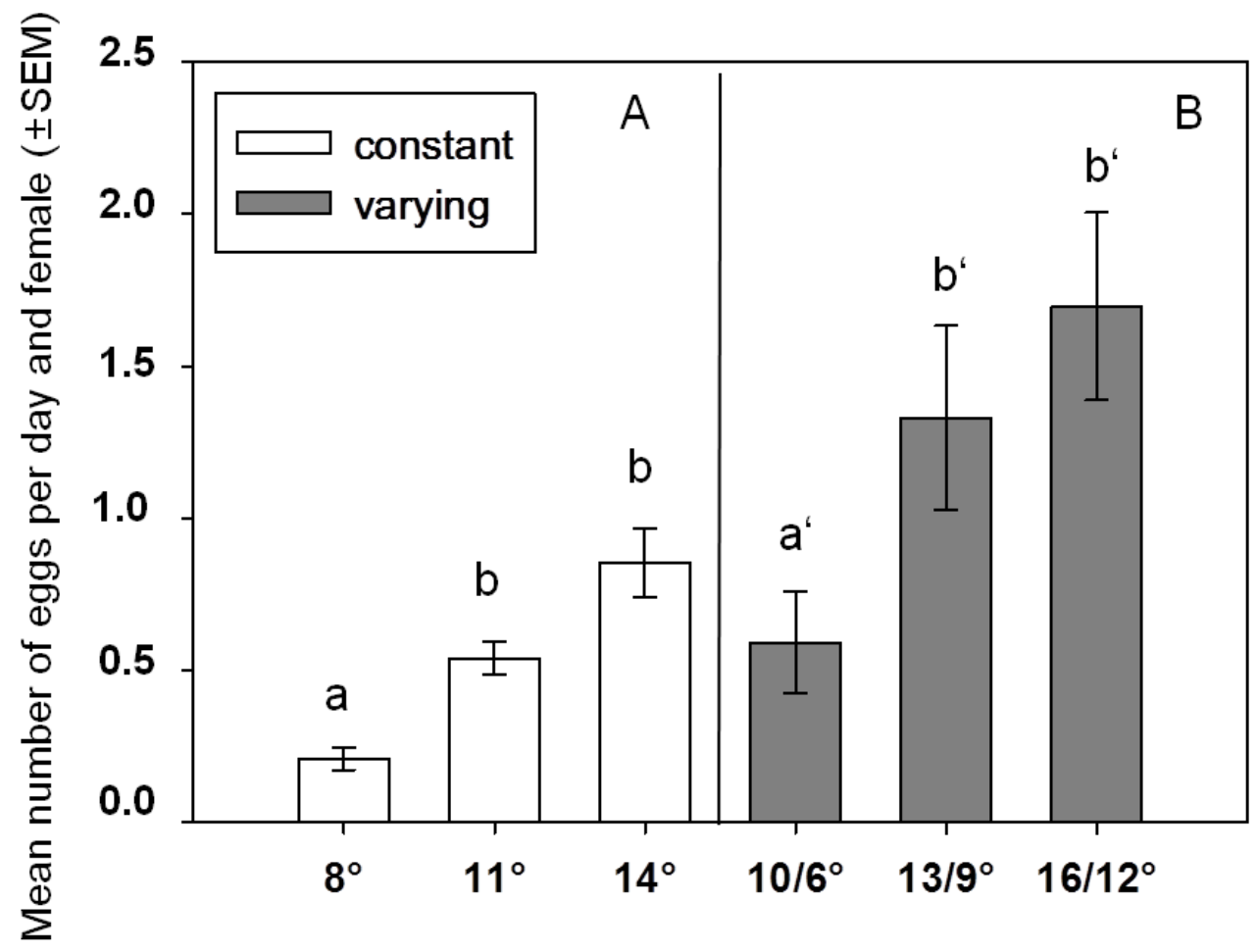

Figure 2: Mean number of laid eggs per day and female for constant and varying temperature regimes with the same mean temperature (different letters indicate significant differences with $\mathrm{H}_{2,45} \mathrm{p}<0,05$ between temperatures and $\mathrm{H}_{1,90} \mathrm{p}<0,01$ between temperature regimes; Kruskal Wallis test)

The total number of eggs laid per female was highest at a constant temperature of $14^{\circ} \mathrm{C}(42.5$ eggs in first three weeks and 51 for the total trial period of nine months). In contrast, at varying temperature regimes, the highest total number of eggs was found at $13 / 9^{\circ} \mathrm{C}$, with 73 eggs per female within three weeks. The most elevated varying temperature regime resulted just in 59 eggs in three weeks.

\section{Performance of adult weevils at different temperature regimes}

The relationship between temperature and fertility and longevity for each temperature regime is given in table 1. There were no significant differences in fertility $(H=1.54, p=0.46)$ and longevity $(H=0.20$, $\mathrm{p}=0.91$ ) of $C$. napi females at different constant temperature regimes. Fertility declined slightly with rising temperatures. Longevity remained similar at all temperature regimes. At each temperature regime, one beetle remained alive until day 247 of the experiment. The shortest live span was 25 days. 
Table 1 Fertility and longevity of $C$. napi females at three different constant temperature regimes. Means followed by the same letter within the same column are not significantly different (Kruskal Wallis test ${ }_{\mathrm{H} 2}, \mathrm{~N}=45 ; 90, \mathrm{p}<0.05$ )

\begin{tabular}{llll}
\hline Temperature & $\mathbf{n}$ & $\begin{array}{l}\text { Fertility } \\
\text { (days, mean } \pm \text { SEM) }\end{array}$ & $\begin{array}{l}\text { Longevity } \\
\text { (days, mean } \pm \text { SEM) }\end{array}$ \\
\hline $\mathbf{8}^{\circ} \mathbf{C}$ & 30 & $111.2 \pm 20.02 \mathrm{a}$ & $125.2 \pm 15.19 \mathrm{a}$ \\
$\mathbf{1 1}^{\circ} \mathbf{C}$ & 30 & $97.9 \pm 11.09 \mathrm{a}$ & $123.9 \pm 13.50 \mathrm{a}$ \\
$\mathbf{1 4 ^ { \circ } \mathbf { C }}$ & 30 & $84.2 \pm 14.31 \mathrm{a}$ & $130.8 \pm 14.39 \mathrm{a}$ \\
\hline
\end{tabular}

\section{Egg development}

Eggs did not hatch at the lowest constant temperature regime $\left(8^{\circ} \mathrm{C}\right)$, but the egg mortality rate was significantly reduced when the varying temperature regime of $10 / 6^{\circ} \mathrm{C}$ was tested versus the constant temperatures $\left(x^{2}=32.56\right.$, d.f. $\left.=1, p<0.05\right)(T a b .2)$. The medium temperature regime varied in their mortality rate $\left(x^{2}=18.26\right.$, d.f. $\left.=1, p<0.005\right)$. However, at the highest temperature regime tested total egg mortality rates did not differ significantly any more $\left(x^{2}=3.38\right.$, d. $\left.f=1 p=0.07\right)$. Developmental time of eggs was significantly delayed for the lowest varying temperature $\left(10 / 6^{\circ} \mathrm{C}\right)$ compared to the elevated temperature regimes tested $(H=13.62, p<0.05)$. Interestingly, increasing the temperature from $11{ }^{\circ} \mathrm{C}$ to $16 / 12^{\circ} \mathrm{C}$ did not significantly reduce the developmental time of eggs $(H=13.61, p=$ 1.00). In this experiment, 42 days was the longest duration for hatching tested at $10 / 6^{\circ} \mathrm{C}$. The shortest time for hatching was 11 days at $16 / 12^{\circ} \mathrm{C}$.

Table 2 Developmental time and mortality rate of $C$. napi eggs in petri dishes with wet filter paper at six different temperature regimes. Means of developmental time followed by the same letter within the same column are not significantly different (Kruskal Wallis test ${ }_{H 4, N=19}, \mathrm{p}<0.05$ ). Egg mortality rates with same letters within the column indicate no significant differences within temperature levels $\left(\mathrm{X}^{2}\right.$ test)

\begin{tabular}{llcl}
\hline Temperature regime & $\mathrm{n}$ & $\begin{array}{l}\text { Developmental time } \\
\text { (days, mean } \pm \text { SEM) }\end{array}$ & $\begin{array}{l}\text { Total } \\
\text { Egg mortality rate }(\%)\end{array}$ \\
\hline $8^{\circ} \mathrm{C}$ & 38 & $0.0 \pm 0.00^{*}$ & $100.0 \mathrm{~A}$ \\
$10 / 6^{\circ} \mathrm{C}$ & 64 & $33.3 \pm 3.24 \mathrm{a}$ & $71.9 \mathrm{~B}$ \\
$11^{\circ} \mathrm{C}$ & 38 & $14.5 \pm 0.29 \mathrm{~b}$ & $71.1 \mathrm{~A}$ \\
$13 / 9^{\circ} \mathrm{C}$ & 63 & $17.2 \pm 0.58 \mathrm{~b}$ & $41.3 \mathrm{~B}$ \\
$14^{\circ} \mathrm{C}$ & 37 & $12.6 \pm 0.56 \mathrm{~b}$ & $56.8 \mathrm{~A}$ \\
$16 / 12^{\circ} \mathrm{C}$ & 64 & $12.6 \pm 0.39 \mathrm{~b}$ & $43.8 \mathrm{~A}$ \\
\hline${ }^{*}$ excluded from statistics & & &
\end{tabular}




\section{Discussion}

The focus of this study was laid on the effect of temperature on fertility, adult longevity and embryonic development of RSWs. First, we tested oviposition, fertility and longevity of adult RSWs under different temperature regimes. RSW females laid more eggs under varying temperature than under constant temperature with the same mean value. Consequently, our hypothesis was confirmed that the temperature has a different influence if it is a constant or varying temperature regime with the same mean (Jalali et al., 2010; Sandhu et al., 2010). It was found for the fertility of crickets, which rose in number per eggs and day until a maximum of productivity was reached, after which a gradual decrease occurred before reproduction finally ceased (Behrens et al., 1983).

We found no significant differences in the fertility at different temperature levels. Low temperatures could result to dysfunctions and therefore lead to a reduced fertility as discovered in other studies (Lessard and Boivin, 2013). Reduced fertility, at best, could reduce the damage caused by the oviposition (Juran et al., 2011). The influence of temperature on the fecundity of RSW females is not yet known. Some authors observed delayed ovary maturation in RSWs over several days depending on the temperature (Johnen et al., 2010). Our own observations (not published) indicated that, in warm spring times, females show almost no maturation feeding. They had fully-developed ovaries at the first catches in the year 2012 and 2013. But these finding have to be clarified with a more detailed monitoring.

One hypothesis was that beetles would survive longer at lower temperatures. As shown in other studies, there was the highest rate of survival recorded at the lowest temperature tested (Jaramillo et al., 2009). For our data, the longevity of adult RSWs was not influenced by the different temperature regimes. Former studies reported that low temperatures during at least a month could have reduced the survival rate and the fecundity of RSW females (Debouzie and Ballanger, 1993) as was found out for other insects (Lessard and Boivin, 2013). One reason could be that our temperature regimes did not differ so much from each other in regard to the thresholds of survival temperature. In contrast, a reduction of adult longevity could result at high constant temperature as well (Behrens et al., 1983; Bayhan et al., 2006).

Many previous studies have investigated the effects of temperature on insect herbivores and their interaction with plants (Bale, 2002; Bale et al., 2002; Dalin, 2011). A number of these studies focused on constant temperatures (Davidson, 1944; Günthart, 1949), which are based on the assumption of average weather data (Gutierrez et al., 2008). In the second experiment, we hypothesized that constant and varying temperature regimes, each with the same daily mean, would differ in the pattern of egg hatch of RSWs. We assumed that eggs, under varying temperature regimes, require less time for development than under constant temperature regimes. Three daily mean temperatures were assessed at constant and varying regimes. Günthart (1949) surveyed the development time of RSW eggs at constant temperatures. His finding was a hatch after 20 days at $8^{\circ} \mathrm{C}$, whereas in our experiment no hatch at all occurred. At a varying temperature regime with the same average daily temperature the development time was significantly longer. With our data, we suggested that a constant $8^{\circ} \mathrm{C}$ was too low for hatching at all, indicating that there are too many dysfunctions inside the egg at this temperature (Lessard and Boivin, 2013). At $11^{\circ} \mathrm{C}$ Günthart (1949) observed a hatch at day 12. This date was found for the varying and constant temperature regime of $14^{\circ} \mathrm{C}$ and $16 / 12^{\circ} \mathrm{C}$ in our 
experiment. Apparently, the populations could have changed in their temperature sensitivity over the decades. Concerning changes like these, day-degree models should be used with caution (Stinner et al., 1974; Wilstermann and Vidal, 2013). Notable is that not the time length of warm treatment alone, but the temperature stimulus itself can make a difference in the development of insects (Behrens et al., 1983). Certain temperatures can be lethal when under constant exposure, whereas integrated in a varying temperature regime the same temperature can be stimulatory (Behrens et al., 1983). But the same temperature level in a varying regime only delayed the egg hatch. This is in line with the data that many insects develop very slowly when temperatures are just a little higher than the threshold (Gilbert and Raworth, 1996). Own observations (not published) have shown, that the larval hatch is possible inside the stem of spring oilseed rape at a constant temperature of $8^{\circ} \mathrm{C}$. Therefore, we assume a different temperature inside the plants. As the temperature in plants is warmer during the day and cooler at night (Tanner, 1963; Keena and Moore, 2010), this fluctuations may provoke larval development of laid eggs. Probably because of this fact, there were larger larvae of a xylophagous species deeper in the bark where the buffering effect was the largest (Keena and Moore, 2010).

The mortality rate of eggs in a petri dish differed between constant and the varying temperature equivalent, although certain mortality factors were excluded, like parasitoids, predators and other natural enemies (Peterson et al., 2009). At constant temperature level the mortality was surprisingly higher in comparison to the varying regimes.

Our results are more general findings, which have to be completed by further research. This data was collected at a local population, and may not hold true for other locations (Pruess, 1983; Keena and Moore, 2010). Another factor to be considered is the nutrition of larvae. The nutritional substrate can influence the developmental rate, whereas the temperature can have an influence on the larval weight which in turn has an influence on the time the larval pupate (Keena and Moore, 2010). Depending on the substrate, the larvae of Anoplophora glabripennis is able to fasten up to pupation when the food moisture declines as a result of a dieback of the host plant (Keena and Moore, 2010). For the RSW the substrate could have a similar effect. As the increasing temperature led to an increased oviposition, there will be more larvae in competition for the same amount of food resources in the WOSR stems. Also, results obtained in this study might provide useful information to RSW biology. Due to our experimental set-up and the difficult rearing of RSWs, we were not able to collect data on larval development. Initial attempts to rear RSWs on spring oilseed rape in the greenhouse to allow such studies unfortunately failed. It would be interesting, though, to complete missing knowledge gaps obtained in this study to achieve a complete temperature sensitivity study, as well as to compare the suitability of different aphidous species or Diabrotica virgifera virgifera (LeConte).

\section{Acknowledgement}

This work was financially supported by the Ministry for Science and Culture of Lower Saxony, Germany, within the research network "KLIFF- climate impact in Lower Saxony". 


\section{References}

Alford DV, Nilsson C, Ulber B, 2003 Insect pests of oilseed rape. In: Alford DV: Biocontrol of oilseed rape pests. Blackwell Science, Oxford, Malden, MA.

Baffoe KO, Dalin P, Nordlander G, Stenberg JA (2012) Importance of temperature for the performance and biocontrol efficiency of the parasitoid Perilitus brevicollis (Hymenoptera: Braconidae) on salix. BioControl DOI: 10.1007/s10526-012-9443-5.

Bale JS (2002) Insects and low temperatures: from molecular biology to distributions and abundance. Philosophical Transactions of the Royal Society B: Biological Sciences. DOI: 10.1098/rstb.2002.1074.

Bale JS, Masters GJ, Hodkinson ID, Awmack C, Bezemer TM, Brown VK, Butterfield J, Buse A, Coulson JC, Farrar J, Good J. E. G., Harrington R, Hartley S, Jones TH, Lindroth RL, Press MC, Symrnioudis I, Watt AD, Whittaker JB (2002) Herbivory in global climate change research: direct effects of rising temperature on insect herbivores. Global Change Biology. DOI: 10.1046/j.13652486.2002.00451.x.

Bayhan E, Ölmez-Bayhan S, Ulusoy MR, Chi H, 2006. Effect of temperature on development, mortality, fecundity, and reproduction of Aphis rumicis L. (Homoptera: Aphididae) on broadleaf dock (Rumex obtusifolius) and Swiss chard (Beta vulgaris vulgaris var. cida). Journal of Pest Science. DOI: 10.1007/s10340-005-0112-7.

Behrens W, Hoffmann K, Kempa S, Gäßler S, Merkel-Wallner G (1983) Effects of diurnal thermoperiods and quickly oscillating temperatures on the development and reproduction of crickets, Gryllus bimaculatus. Oecologia. DOI: 10.1007/BF00378849.

Büchi R (1996) Eiablage des Rapsstengelrüßlers Ceutorhynchus napi Gyll., in Abhängigkeit der Stengellänge bei verschiedenen Rapssorten. Anzeiger für Schädlingskunde, Pflanzenschutz, Umweltschutz 69. DOI: 10.1007/BF01904715.

Dalin P (2011) Diapause induction and termination in a commonly univoltine leaf beetle (Phratora vulgatissima). Insect Science. DOI: 10.1111/j.1744-7917.2011.01417.x.

Davidson J (1944) On the relationship between temperature and rate of development of insects at constant temperatures. Journal of Animal Ecology. DOI: 10.2307/1326.

Debouzie D, Ballanger Y (1993) Dynamics of a Ceutorhynchus napi population in winter rape fields Acta oecologica 14: 603-618.

Gilbert N, Raworth D (1996) Insects and temperature - a general theory. Canadian Entomologist 128, $1-13$.

Günthart E (1949) Beiträge zur Lebensweise und Bekämpfung von Ceuthorrhynchus quadriens PANZ. und Ceuthorrhynchus napi GYLL. mit Beobachtungen an weiteren Kohl- und Rapsschädlingen. Mitteilungen der Schweizerischen Enotmologischen Gesellschaft 22, 441-591.

Gutierrez AP, Ponti L, d'Oultremont T, Ellis CK (2008) Climate change effects on poikilotherm tritrophic interactions. Climatic Change. DOI: 10.1007/s10584-007-9379-4.

Hagstrum DW, Hagstrum WR (1970) A Simple Device for Producing Fluctuating Temperatures, with an Evaluation of the Ecological Significance of Fluctuating Temperatures. Annals of the Entomological Society of America 63, 1385-1389.

Hagstrum DW, Leach CE (1973) Role of Constant and Fluctuating Temperatures in Determining Development Time and Fecundity of Three Species of Stored-Products Coleoptera. Annals of the Entomological Society of America 66, 407-410.

Hagstrum DW, Milliken GA (1991) Modeling Differences in Insect Developmental Times between Constant and Fluctuating Temperatures. Annals of the Entomological Society of America 84, 369-379. 
Higley L, Pedigo L, Ostlie K (1986) DEGDAY: A Program for calculating Degree-days, and Assumptions Behind the Degree-day Approach. Environmental Entomology 15, 999-1016.

Jalali MA, Tirry L, Clercq P (2010) Effect of temperature on the functional response of Adalia bipunctata to Myzus persicae. BioControl. DOI: 10.1007/s10526-009-9237-6.

Jaramillo J, Chabi-Olaye A, Kamonjo C, Jaramillo A, Vega FE, Poehling H, Borgemeister C, Rands S (2009) Thermal tolerance of the coffee berry borer Hypothenemus hampei: Predictions of climate change impact on a tropical insect pest. PLoS ONE. DOI: 10.1371/journal.pone.0006487.

Johnen A, Williams I, Nilsson C, Klukowski Z, Luik A, Ulber B (2010) The proPlant Decision Support System: Phenological Models for the Major Pests of Oilseed Rape and Their Key Parasitoids in Europe. In: Williams I (ed): Biocontrol-based integrated management of oilseed rape pests, Springer, Dordrecht; London, pp13-16

Juran I, Gotlin Culjak T, Grubisic D (2011) Rape Stem Weevil (Ceutorhynchus napi Gyll. 1837) and Cabbage Stem Weevil (Ceutorhynchus pallidactylus Marsh. 1802) (Coleoptera: Curculionidae) Important Oilseed Rape Pests. Agriculturae Conspectus Scientificus 76, 93-100.

Keena MA, Moore PM (2010) Effects of Temperature on Anoplophora glabripennis. Environmental Entomology. DOI: 10.1603/EN09369.

Lessard E, Boivin G (2013) Effect of low temperature on emergence, fecundity, longevity and hostfeeding by Trichogramma brassicae. BioControl. DOI: 10.1007/s10526-012-9493-8.

Marazzi C, Patrian B, Städler E (2004) Secondary metabolites of the leaf surface affected by sulphur fertilisation and perceived by the diamondback moth. Chemoecology. DOI: 10.1007/s00049-003-0264y.

Marazzi C, Städler E (2004) Arabidopsis thaliana leaf-surface extracts are detected by the cabbage root fly (Delia radicum) and stimulate oviposition. Physiological Entomology. DOI: 10.1111/j.03076962.2004.00384.x.

Mewis I, Ulrich C, Schnitzler W (2002) The role of glucosinolates and their hydrolysis products in oviposition and host-plant finding by cabbage webworm, Hellula undalis. Entomologia Experimentalis et Applicata 105, 129-139.

Peterson RKD, Davis RS, Higley LG, Fernandes OA (2009) Mortality risk in insects. Environmental Entomology. DOI: 10.1603/022.038.0102.

Pruess K (1983) Day-Degree Methods for Pest Management. Environmental Entomology 12, 613 619.

Rusch A, Valantin-Morison M, Sarthou J, Roger-Estrade J (2013) Effect of crop management and landscape context on insect pest populations and crop damage. Agriculture, Ecosystems \& Environment. DOI: 10.1016/j.agee.2011.05.004.

Sandhu HS, Nuessly GS, Webb SE, Cherry RH, Gilbert RA (2010) Temperature-Dependent Development of Elasmopalpus lignosellus (Lepidoptera: Pyralidae) on Sugarcane Under Laboratory Conditions. Environmental Entomology. DOI: 10.1603/EN09284.

Satar S, Kersting U, Uygun N (2005) Effect of temperature on development and fecundity of Aphis gossypii Glover (Homoptera: Aphididae) on cucumber. Journal of Pest Science. DOI: 10.1007/s10340005-0082-9.

Stinner RE, Gutierrez AP, Butler Jr. GD (1974) An algorithm for temperature-dependent growth rate simlation. Canadian Entomologist. DOI: 10.4039/Ent106519-5.

Tanner CB (1963) Plant Temperatures. Agronomy Journal. DOI: 10.2134/agronj1963.00021962005500020043x. 
Taylor L (1963) Analysis of the Effect of Temperature on Insects in Flight. Journal of Animal Ecology 32, 99-117.

Veromann E (2013) Effects of nitrogen fertilization on insect pests, their parasitoids, plant diseases and volatile organic compounds in Brassica napus. Crop Protection 43, 79-88.

Wang L, Shi P, Chen C, Xue F (2013): Effect of Temperature on the Development of Laodelphax striatellus (Homoptera: Delphacidae). Journal of Economic Entomology. DOI: 10.1603/EC12364.

Wilstermann A, Vidal S (2013) Western corn rootworm egg hatch and larval development under constant and varying temperatures. Journal of Pest Science. DOI: 10.1007/s10340-013-0496-8. 


\title{
Herbivory and drought change volatile emissions of oilseed rape (Brassica napus L.)
}

A. REINHARDT ${ }^{1}$, M. von FRAGSTEIN und NIEMSDORFF' ${ }^{2}$ B. ULBER ${ }^{1}$, S. SCHÜTZ ${ }^{2}$ and S. VIDAL ${ }^{1}$

${ }^{1}$ Georg-August University, Department of Crop Sciences, Agricultural Entomology, Grisebachstr. 6, 37077 Goettingen, Germany,

${ }^{2}$ Georg-August University, Department of Forest Zoology and Forest Conservation, Buesgen Institute, Büsgenweg 3, 37077 Goettingen, Germany

email: svidal3@gwdg.de

\begin{abstract}
The profile of volatile organic compounds (VOCs) can be used as an indicator for plant fitness. In this study, the VOCs of oilseed rape (Brassica napus L.) subjected to herbivory by rape stem weevil adults (Ceutorhynchus napi GYLL.) and drought were studied using a dynamic headspace technique. Three treatments were set up. In the first treatment the plants were regularly watered and damaged by feeding rape stem weevils. In the second treatment the plants was watered irregularly by lowering the amount of water to cause drought stress. The third group of plants served as the control with regular watering and no RSW infestation. We hypothesized that the analyzed VOC profiles should differ between the tested treatments with a reduced emission caused by drought due to the limited supply with water as a carrier for nutrients. The identified VOC blends were mostly similar between the treatments but differed in their intensity. Especially VOC emissions by plants with drought stress were significantly different to plants in the control. In contrast to our hypothesis, however, drought stress had the higher emission of VOC per gram fresh weight than regularly watered control plants. As plant parameters, such as phenological development, were affected by drought stress. The VOC emission is highly depending on the plant status.
\end{abstract}

Key Words - Ceutorhynchus napi, Coleoptera, Brassica napus, Drought stress, Herbivory, Plant volatiles

\section{Introduction}

Many herbivorous insects use volatile organic compounds (VOCs) to locate their host plants (Thorsteinson, 1960). VOCs can be classified into general compounds, like green leaf volatiles, and specific VOCs, which are more represented by specific plant families (Visser, 1986). Either the particular ratio of more general compounds or a specific compound is representative for each plant species (Visser, 1986). Sometimes the green leaf volatiles play a role in overall perception and host recognition (Evans and Allen-Williams, 1992; Hansson et al., 1999). In other cases the specific odor of a plant attracts their associated insects (Bartlet, 1996; Marazzi and Stadler, 2004). Each plant species produces an herbivore-specific blend of volatile components in response to a particular herbivorous insect feeding on the leaves, and these differences are quantified by headspace analyses (Paré and 
Tumlinson, 1999). Intact plants release their major VOC emission permanently (Turlings and Tumlinson, 1992; Jakobsen et al., 1994; Röse et al., 1996). In general, leaves release small quantities of volatile chemicals, but when a plant is damaged by herbivorous insects, larger amounts of volatiles are released (Boland et al., 1992; Paré and Tumlinson, 1999).There is a difference in the VOC profile from a mechanically damaged plant and an herbivore-infested plant (Mattiacci et al., 1995). The herbivore induced VOC profiles are only emitted when specific enzymes from the saliva of insects are present (Boland et al., 1992). In cabbage $\beta$-glucosidase, present in the regurgitant of Pieris brassicae caterpillars, triggers the same emissions of volatiles as caused by feeding caterpillars (Mattiacci, 1995). The blend of herbivore-induced VOCs can consist of 20 - 200 changes in altered emission rates or newly generated VOCs (Dicke and Loon, 2000). These differences in the emission can be used by predators and parasitoids as scents of herbivore-attacked plants to locate their hosts (Boland et al., 1992) or follow the herbivore-induced VOCs to find their prey (Dicke and Loon, 2000). Some studies consider this as indirect plant defense, where predators help the plant to reduce the negative effect of herbivory (Dicke and Loon, 2000).

Insects locate their host first by visual factors (Bartlet, 1996). Once the insect is in an appropriate habitat, olfaction is used to locate the host-plant (Feeny, 1977). The appropriate plant has a positive chemical reaction on the basis of their VOC profile (Feeny, 1977; Bartlet, 1996). Cruciferous plants, such as oilseed rape (OSR - Brassica napus L.), emit a complex mixture of VOCs (Bartlet, 1993; Schiestl, 2010). Insects use this blend to attack OSR and thereby reduce the yield (Blight et al., 1995, Cook et al., 2007b; Cook et al., 2007a).

The rape stem weevil (RSW - Ceutorhynchus napi Gyll.) is the first pest of oilseed rape appearing in spring (Günthart, 1949). This weevil is extremely harmful to OSR (Dechert and Ulber, 2004). The damage is caused after oviposition of eggs, as the presence of the egg in the stem induces a canker in the growing tissue. This leads to characteristic deformations of the stem such as dwarfism, twisting, bursting, as well as a premature ripening (Juran et al., 2011). So far, nothing is known about the influence of herbivory caused by RSWs on the VOC profile of OSR.

Chemical changes of VOC profiles can be either seasonal, day-night or inter-year effects (Maarse and Kepner, 1970; Visser, 1986; Veromann, 2013). Beside these abiotic changes also biotic stress can change the blend of VOCs (Holopainen and Gershenzon, 2010; Niinemets, 2010; Toome et al., 2010; Copolovici et al., 2011, Vuorinen, 2004). Herbivory as a stress factor for plants can change the VOC profile. It is also interesting to examine other stress factors like water shortage caused by altered water availability as a result of climate change. There seems to be little doubt that the global climate is changing, partly due to natural factors, but mainly through human activities (Karl and Trenberth, 2003; Eitzinger et al., 2010). As climate change results in modified temperature, we can expect insect herbivores and their interactions with host-plants to be affected (Gutierrez et al., 2008; Jalali et al., 2010). The same could be assumed for changes in precipitation. The forecast models predict a medium confidence level of droughts in Europe (Field, 2012). Elevated air temperatures result in an increased evaporation from the soil and higher transpiration from the plants which subsequently causes drought stress (Harte et al., 1995; Eitzinger et al., 2010). As water is essential for in-plantatransportation of nutrients (Bray, 2004), drought in plants influences growth and fecundity of the associated insect fauna (Mattson and Haack, 1987). Some studies concentrated on climate change 
with respect to the altered water availability for plants and its use (e.g. Eitzinger et al., 2010) whilst other studies investigated the effects of temperature on insect herbivores and their interaction with plants (Steinbauer, 2004; Dalin, 2011). Consequently, there is an of host plant quality on insects (Marazzi et al., 2004; Peterson et al., 2009). The quantitative change in VOC emissions upon herbivory alters the interaction between the plant and its environment (Dicke and Loon, 2000). This study focused on the interaction between herbivory caused by RSW and OSR and the effect of drought on OSR.

We analyzed the VOC emission of OSR plants three different treatments. The first treatment consisted of intact and well-watered OSR plants representing the control group. The second treatment was made up of well-watered RSW infested OSR plants. In the third treatment intact OSR plants were exposed to drought stress. Our hypothesis was that a change in emission of different VOC blends between the treatments of drought stressed OSR plants emit less VOCs because of their limited resources and closed stomata (Hsiao, 1973; Qaderi et al., 2006). These results are regarded as important for modeling shifts in host finding for RSWs due to changes in water availability leading to drought stress in OSR plants. Additionally, we assessed plant parameters of the drought stressed and well-watered plants and hypothesized that drought stress has a negative effect on the plant development.

\section{Methods \& Materials Insect sampling and plant treatment}

Black soil (Chernozem) was brought from a nearby field in Goettingen, Germany $\left(51.507432^{\circ} \mathrm{N}\right.$, $9.887492^{\circ} \mathrm{E}$ ) to the laboratory. The soil was steamed at $90^{\circ} \mathrm{C}$ and dried in a greenhouse at $20^{\circ} \mathrm{C}$ for 14 days. The soil was then mixed with 1/6 Perlite ${ }^{\circledR}$ (insulation fabric, Knauf Aquapanel GmbH, Dortmund, Germany) to prevent soil from clogging in the pots. $1.2 \mathrm{~kg}$ of the soil mix was weight and mixed with $180 \mathrm{ml}$ tap water and filled in the pots. (Pot size: $13 \mathrm{~cm} \times 13 \mathrm{~cm} \times 13 \mathrm{~cm}$ ). The test plants (Brassica napus L. cv 'Mozart') were cultivated in the greenhouse. Seeds were sown in mixed soil substrate, composed by three parts of potting soil (Fruhstorfer Erde (Typ 25), Hawita Gruppe GmbH, Vechta, Germany) and one sand. After 24 hours, the OSR seedlings were removed from their precultivation pot. The potting soil was carefully washed off the seedlings. The seedlings were transplanted into the prepared soil mix. $40 \mathrm{ml}$ of tap water was added to the plants to guarantee soil moisture of $40 \%$ (effective field capacity). Pots were placed in a growth chamber with a photoperiod of $16 \mathrm{~h}$ light and $8 \mathrm{~h}$ darkness at a constant temperature of $18{ }^{\circ} \mathrm{C}$ and $85 \%$ air humidity. The plants were watered every second day by placing every single plant on a scale and adjusting the amount of water needed to the normal weight. To consider the gained weight by growing plants, extra plants were harvested and weighed to adjust the normal weight. One week before the headspace analyses soil moisture of five plants was adjusted to $10 \%$ soil moisture. 10 plants were watered to maintain $40 \%$ soil moisture.

We used RSWs collected during the main flight activity in March with empty yellow water traps (Syngenta Agro $\mathrm{GmbH}$, Maintal, Germany). Until the start of the trial, they were kept in plastic boxes $\left(17.5 \mathrm{~cm} * 13 \mathrm{~cm}{ }^{*} 6 \mathrm{~cm}\right.$, Neupack Verpackungen GmbH \& Co. KG. Hamburg, Germany) with leaves of OSR from the greenhouse as food supply and a dry paper tissue (Tork Universal, SCA Hygiene 
Products AFH Sales GmbH, Mannheim, Germany) to absorb condensation. The boxes were stored in a climate chamber with a constant temperature of $14{ }^{\circ} \mathrm{C}$ and a light regime of $12 \mathrm{~h}$ light and $12 \mathrm{~h}$ darkness. Boxes and food were changed weekly to prevent any microbial contamination.

All plants were transferred to an air-conditioned room $24 \mathrm{~h}$ prior to the feeding tests. The temperature in the room was $25.5^{\circ} \mathrm{C}$, with a relative humidity of $42 \%$ and a dew point of $11.5^{\circ} \mathrm{C}$. Two RSWs were each caged within one clip cage $(\varnothing 60 \mathrm{~mm}$, height $15 \mathrm{~mm}$, coated with gauze $(0.02 \mathrm{~mm})$, rim covered with $5 \mathrm{~mm}$ foam material) on five plants with soil moisture of $40 \%$ to provide feeding. The feeding was terminated after $48 \mathrm{~h}$ by removing the weevils from the plant. The following plant growth parameters were assessed: phenological stage BBCH (Lancashire et al. (1991)), plant height, and fresh weight. Fresh weight was determined by weighing the freshly cut plants.

\section{Volatile sampling, GC-MS and data analyses}

Headspace analyses were performed in the same climate room as the feeding tests. Directly after removing the RSWs from the plants, VOCs from all six-weeks-old plants were sampled on TenaxH adsorbent traps (TDS, Gerstel, Mülheim, Germany) using a modified push-pull headspace collection system (Tholl et al., 2006) directly on the OSR plants. For VOC sampling OSR plants were enclosed in an inert plastic oven bag (Melitta $\mathrm{GmbH}$, Minden, Germany), excluding existing flowers or buds. Air was circulated through the trap by a miniature pump (Fürgut, Aichstetten, Germany) at a flow of 0.8 I $\min ^{-1}$. The sampling time was $2 \mathrm{~h}$.

Volatile samples on Tenax TA tubes were thermo desorbed in a TDS 2 system (Gerstel, Mühlheim, Germany) heated at $280^{\circ} \mathrm{C}$ for 3 min with a helium (Helium 5.0, AirLiquid, Germany, (purity $99.999 \%$ ) flow of $40 \mathrm{ml} / \mathrm{min}$. Volatiles were cryo-focused on a cold injection system CIS 4 (Gerstel) at $-75^{\circ} \mathrm{C}$. Volatile samples were analyzed with a gas chromatograph Agilent type 6890 connected to a Agilent type 5973 quadrupole mass spectrometer (both Palo Alto, USA) with electron ionization (EI, $70 \mathrm{eV}$ ). A HP-5 ms (Agilent, $30 \mathrm{~m}, 0.25 \mathrm{~mm}$ ID, and $0.25 \mathrm{Im}$ film thickness, phenylmethylsiloxane) were used to analyze the composition of the VOC samples. The oven temperature program was $40{ }^{\circ} \mathrm{C}$ held for 3 min, followed by an increase of $7.50{ }^{\circ} \mathrm{C} \mathrm{min}-1$ to $250^{\circ} \mathrm{C}$, remaining at $250{ }^{\circ} \mathrm{C}$ for $5 \mathrm{~min}$ (Weissteiner et al., 2012).

For identification of the constituents, mass spectra GC retention values and linear retention indices were compared to those of authentic standards and those of the mass spectral databases. Databases used, were Wiley 9 combined with NIST 08 and "Terpenoids and Related Constituents of Essential Oils", a database available from MassFinder 3.07 software (Hochmuth Scientific Consulting, Hamburg, Germany).

\section{Statistical Analyses}

Statistical analyses were carried out using the software R, Version 2.13.2 (R Development Core Team2011). Generalized Linear Models ("glm"-function in package "stats and MASS") were used to test the differences of total emissions of plant VOCs and differences of distinct compounds among the three treatments (Venables and Ripley, 1997). Multiple Comparisons between treatments were calculated using Tukey contrasts with $p$-values adjusted by single-step method ("multcomp"-package) (Hsu, 1996). Results were assessed for significance at $p<0.05$. 


\section{Results}

Volatile compounds of intact OSR plants were shown to comprise highly complex mixtures. The control plants emitted 27 VOCs, whereas the treatments herbivore attacked emitted 29 and the drought stressed plants only 26 compounds. As the total ion chromatogram (Fig. 1) did not show all differences in detail, the statistical analyses had a closer look.
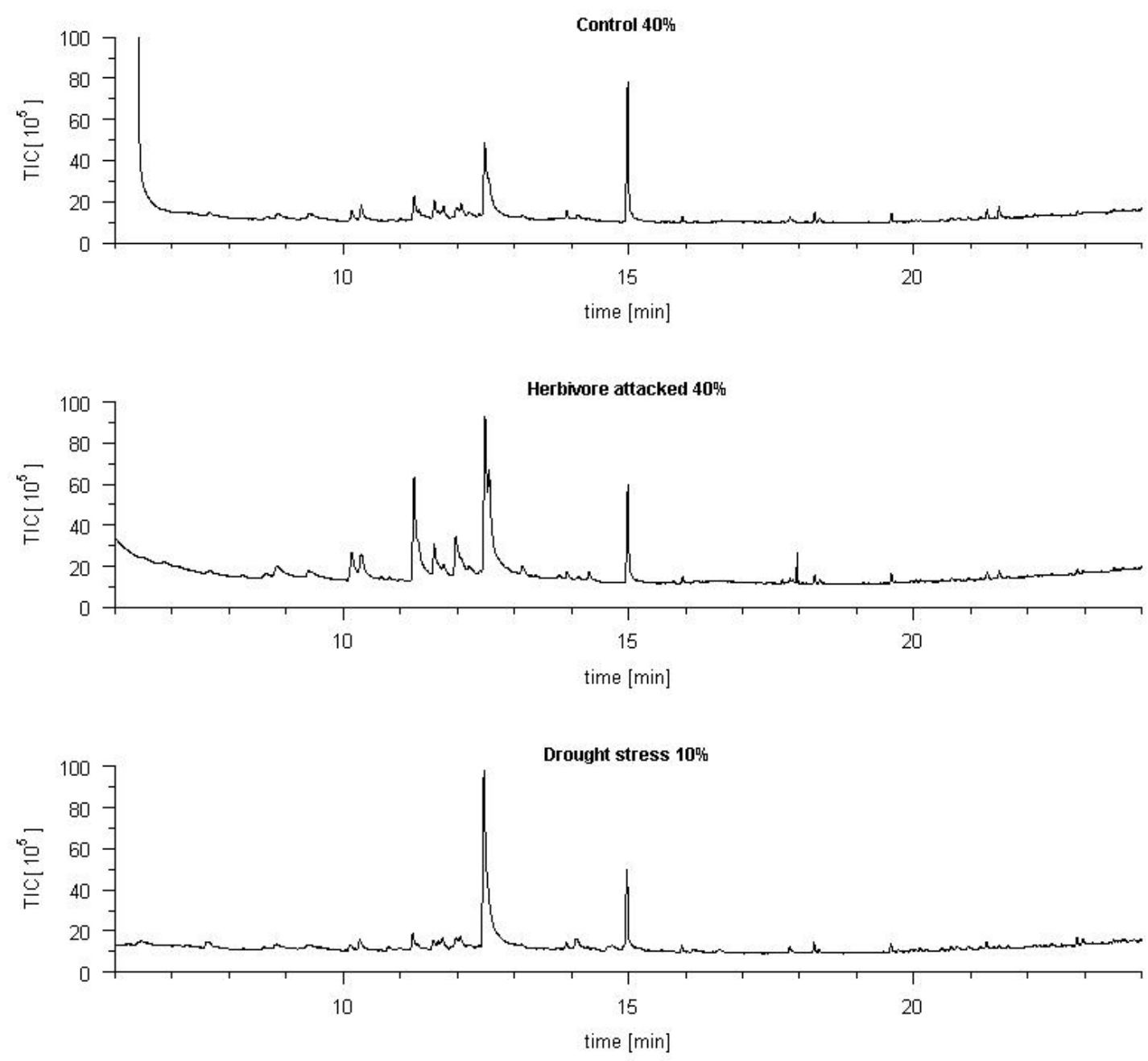

Figure 1. Total ion chromatograms of headspace analysis of OSR plants that underwent different treatments.

Despite the number of specific compounds, quantitative differences were found for the different treatments. The control plants varied in comparison to the treatment with the herbivore-infested plants. Herbivory resulted in increasing amounts of $\alpha$-thujene, sabinene, $\beta$-pinene and 2,4,4-trimethyl-2pentanethiol. A significant reduction in the production of compounds was recorded for nonanal, undecane, 2-ethylhexyl acetate and camphor. E-4,8-dimethyl-1,3,7-nonatriene was absent in the control plants and about ten times higher in herbivore attacked plants in comparison to drought stressed plants. The control and the herbivore attacked plants differed in comparison to drought stressed plants in terms of alkanes (decane, dodecane, tridecane and tetradecane) and the monoterpene delta-3-carene. 1-dodecene and 2,4,4-trimethyl-2-pentanethiol were not detected in drought stressed plants. Methyl-2-ethyl hexanoate is only detected for the herbivore attacked plants. The control and drought stressed plants did not differ in its quantities of nonanal, undecane, 
pentadecane, methyl-2-ethyl hexanoate, 2-ethylhexyl acetate, 3-heptanone, $\alpha$-thujene, sabinene, $\beta$ pinene and D/L-limonene / 2-ethyl-1-hexanol. When comparing the quantities between both stress types, most disparities were observed between drought and herbivory stressed plants than between stressed plants and control plants. The lowest total amounts of VOCs were detected with the control plants $\left(3.73 * 10^{6} \mathrm{ng} \mathrm{g}^{-1}\right.$ fresh weight \pm SEM $\left.7.36 * 10^{5}\right)$. Herbivory increased the total amount of VOCs to $4.57 * 10^{6} \mathrm{ng} \mathrm{g}^{-1}$ fresh weight $\left( \pm\right.$ SEM $1.00 * 10^{6}$ ). The highest emission of volatiles was recorded for drought stressed plants $\left(6.77 * 10^{6} \mathrm{ng} \mathrm{g}^{-1}\right.$ fresh weight $\left( \pm\right.$ SEM $\left.\left.5.44 * 10^{6}\right)\right)$.

Table 1. Identified volatiles in three different treatments of OSR plants (Peak area/1 kg fresh weight)

\begin{tabular}{|c|c|c|c|c|c|c|c|c|c|c|c|c|c|c|}
\hline & \multirow{3}{*}{\multicolumn{4}{|c|}{$\begin{array}{c}\text { Control } 40 \% \\
\text { mean } \\
\pm \\
\text { SEM } \\
n=5 \\
\end{array}$}} & \multirow{3}{*}{\multicolumn{4}{|c|}{$\begin{array}{c}\text { Herbivore attacked } 40 \% \\
\text { mean } \\
\pm \\
\mathrm{SEM} \\
\mathrm{n}=5 \\
\end{array}$}} & \multirow{3}{*}{\multicolumn{4}{|c|}{$\begin{array}{c}\text { Drought stress } 10 \% \\
\text { mean } \\
\pm \\
\text { SEM } \\
n=5 \\
\end{array}$}} & \multicolumn{2}{|c|}{ GLM-results } \\
\hline & & & & & & & & & & & & & \multirow{2}{*}{\multicolumn{2}{|c|}{\begin{tabular}{c|c}
$\begin{array}{c}\text { F- } \\
\text { values }\end{array}$ & $\begin{array}{c}\mathrm{p}- \\
\text { values }\end{array}$ \\
$\mathbf{d f}=\mathbf{2}, \mathbf{1 2}$ \\
\end{tabular}}} \\
\hline & & & & & & & & & & & & & & \\
\hline & \multicolumn{14}{|c|}{ Aldehyde } \\
\hline Nonanal & 102.05 & \pm & 21.31 & $b$ & 86.40 & \pm & 18.24 & $a$ & 214.92 & \pm & 40.52 & $b$ & 6.484 & 0.012 \\
\hline \multicolumn{15}{|l|}{ Alkane } \\
\hline 3-methylene-Heptane & 152.06 & \pm & 79.68 & $a$ & 317.96 & \pm & 162.40 & $a$ & 33.18 & \pm & 33.18 & $a$ & 2.559 & 0.119 \\
\hline 4-methyl octane & 80.63 & \pm & 28.53 & $a$ & 79.83 & \pm & 19.10 & $a$ & 63.22 & \pm & 24.77 & $a$ & 0.164 & 0.851 \\
\hline Decane & 151.68 & \pm & 19.32 & $a$ & 148.08 & \pm & 22.00 & $a$ & 260.51 & \pm & 35.32 & $b$ & 5.930 & 0.016 \\
\hline Undecane & 100.75 & \pm & 14.04 & $a$ & 80.26 & \pm & 9.17 & $a$ & 159.71 & \pm & $3,773.09$ & $a b$ & 3.653 & 0.058 \\
\hline Dodecane & 39.51 & \pm & 3.15 & $a$ & 34.02 & \pm & 4.59 & $a$ & 74.17 & \pm & 17.27 & $b$ & 5.598 & 0.019 \\
\hline Tridecane & 49.93 & \pm & 5.44 & $a$ & 40.11 & \pm & 4.84 & $a$ & 90.88 & \pm & 12.03 & $b$ & 12.436 & 0.001 \\
\hline Tetradecane & 39.63 & \pm & 4.26 & $a$ & 30.15 & \pm & 1.61 & $a$ & 54.69 & \pm & 4.54 & $b$ & 11.938 & 0.001 \\
\hline Pentadecane & 52.63 & \pm & 12.07 & $a b$ & 34.08 & \pm & 3.14 & $a$ & 62.41 & \pm & 8.88 & $b$ & 3.017 & 0.087 \\
\hline \multicolumn{15}{|l|}{ Alkatrienes } \\
\hline $\begin{array}{l}\text { (E)-4,8-Dimethyl- } \\
\text { 1,3,7-nonatriene }\end{array}$ & 0.00 & \pm & 0.00 & $a$ & 106.17 & \pm & 18.91 & $b$ & 10.24 & \pm & 10.24 & $a b$ & 20.557 & 0.000 \\
\hline \multicolumn{15}{|l|}{ Alkenes } \\
\hline 1-Dodecene & 5.67 & \pm & 2.43 & $b$ & 9.91 & \pm & 2.00 & $b$ & 0.00 & \pm & 0.00 & $a$ & 14.324 & 0.001 \\
\hline 1-Tetradecene & 8.17 & \pm & 1.97 & $a$ & 13.27 & \pm & 2.39 & $a$ & 19.93 & \pm & 6.97 & $a$ & 2.291 & 0.144 \\
\hline \multicolumn{15}{|l|}{ Alcohol } \\
\hline 1,8-Cineole & 312.48 & \pm & 84.60 & $a$ & 588.95 & \pm & 109.89 & $a b$ & 975.32 & \pm & 192.06 & $b$ & 6.673 & 0.011 \\
\hline \multicolumn{15}{|l|}{ Ester } \\
\hline (Z)-3-hexenyl acetate & 81.38 & \pm & 23.41 & $a$ & 153.96 & \pm & 59.49 & $a$ & 90.52 & \pm & 55.69 & $a$ & 0.643 & 0.543 \\
\hline $\begin{array}{l}\text { Methyl-2-ethyl } \\
\text { hexanoate }\end{array}$ & 0.00 & \pm & 0.00 & $a$ & 142.70 & \pm & 31.37 & $b$ & 0.00 & \pm & 0.00 & $a$ & 68.194 & $<0.0001$ \\
\hline 2-Ethylhexyl acetate & 581.78 & \pm & 67.60 & $b$ & 334.34 & \pm & 33.25 & $a$ & 755.36 & \pm & 98.49 & $b$ & 10.536 & 0.002 \\
\hline \multicolumn{15}{|l|}{ Ketone } \\
\hline 3-Heptanone & 31.11 & \pm & 9.05 & $a b$ & 36.60 & \pm & 4.55 & $b$ & 9.74 & \pm & 6.37 & $a$ & 3.703 & 0.056 \\
\hline 3-Octanone & 24.73 & \pm & 12.51 & $a$ & 26.70 & \pm & 6.87 & $a$ & 49.39 & \pm & 21.41 & $a$ & 0.913 & 0.428 \\
\hline \multicolumn{15}{|l|}{ Monoterpene } \\
\hline$\alpha$-Thujene & 71.35 & \pm & 4.37 & $b$ & 174.62 & \pm & 40.53 & $a$ & 115.70 & \pm & 14.21 & $a b$ & 5.932 & 0.016 \\
\hline$\alpha$-Pinene & 156.23 & \pm & 9.67 & $a$ & 238.26 & \pm & 41.44 & $a$ & 233.69 & \pm & 49.09 & $a$ & 1.776 & 0.213 \\
\hline Sabinene & 125.57 & \pm & 15.58 & $a$ & 332.98 & \pm & 60.78 & $b$ & 207.47 & \pm & 22.65 & $a$ & 9.556 & 0.003 \\
\hline$\beta$-Pinene & 69.46 & \pm & 7.32 & $a$ & 150.96 & \pm & 29.59 & $b$ & 107.72 & \pm & 10.68 & $a b$ & 6.075 & 0.015 \\
\hline$\beta$-Myrcene & 145.60 & \pm & 25.83 & $a$ & 169.91 & \pm & 34.67 & $a$ & 145.98 & \pm & 10.52 & $a$ & 0.300 & 0.747 \\
\hline Delta-3-Carene & 151.07 & \pm & 28.57 & $a$ & 140.71 & \pm & 35.47 & $a$ & 288.18 & \pm & 40.08 & $b$ & 4.986 & 0.027 \\
\hline $\begin{array}{l}\text { D/L-Limonene / } \\
\text { 2-Ethyl-1-hexanol }\end{array}$ & 928.43 & \pm & 205.34 & $a b$ & 798.90 & \pm & 186.50 & $a$ & $2,345.27$ & \pm & 848.50 & $b$ & 3.834 & 0.052 \\
\hline$\gamma$-Terpinene & 111.91 & \pm & 24.66 & $a$ & 158.04 & \pm & 32.67 & $a b$ & 250.59 & \pm & 62.66 & $b$ & 3.044 & 0.085 \\
\hline \multicolumn{15}{|l|}{ Sesquiterpene } \\
\hline$(E, E)-\alpha$-Farnesene & 65.10 & \pm & 9.69 & $a$ & 79.35 & \pm & 17.72 & $a$ & 46.86 & \pm & 9.31 & $a$ & 1.758 & 0.214 \\
\hline \multicolumn{15}{|l|}{ Terpenoid } \\
\hline Camphor & 85.04 & \pm & 8.91 & $b$ & 36.49 & \pm & 4.25 & $a$ & 104.02 & \pm & 28.28 & $b$ & 5.878 & 0.017 \\
\hline \multicolumn{15}{|l|}{ unknown class } \\
\hline $\begin{array}{l}\text { 2,4,4-trimethyl-2- } \\
\text { Pentanethiol }\end{array}$ & 6.99 & \pm & 6.99 & $b$ & 29.01 & \pm & 6.16 & $a$ & 0.00 & \pm & 0.00 & $a b$ & 7.890 & 0.006 \\
\hline
\end{tabular}

Results based on GC-MS analyses; glm; multiple comparisons between treatments followed by using Tukey contrasts with $p$ values adjusted by single-step method; different letters indicate significant differences; $p<0.05$ 
Control plants and herbivore infested plants did not differ in plant growth stage, height and fresh weight. The results of these two treatments were therefore combined to compare (figure 2).

The plant height was affected by the drought stress. Well-watered plants as well as herbivoredamaged plants had a mean height of $62 \mathrm{~cm}( \pm 1.04$ SEM) and drought stressed plants $31.5 \mathrm{~cm} \mathrm{( \pm}$ 0.56 SEM), respectively. Consequently, the growth stage was reduced. Control plants were fully flowering (BBCH 63). The drought stressed plants just had their flower buds raised over the youngest leaves $(\mathrm{BBCH} 53)$. The fresh weight was reduced. Well-watered plants had a total fresh weight of above ground matter of $36.68 \mathrm{~g}( \pm 2.15 \mathrm{SEM})$ and drought stressed plants had a fresh weight of 21.40 $g( \pm 1.30$ SEM).
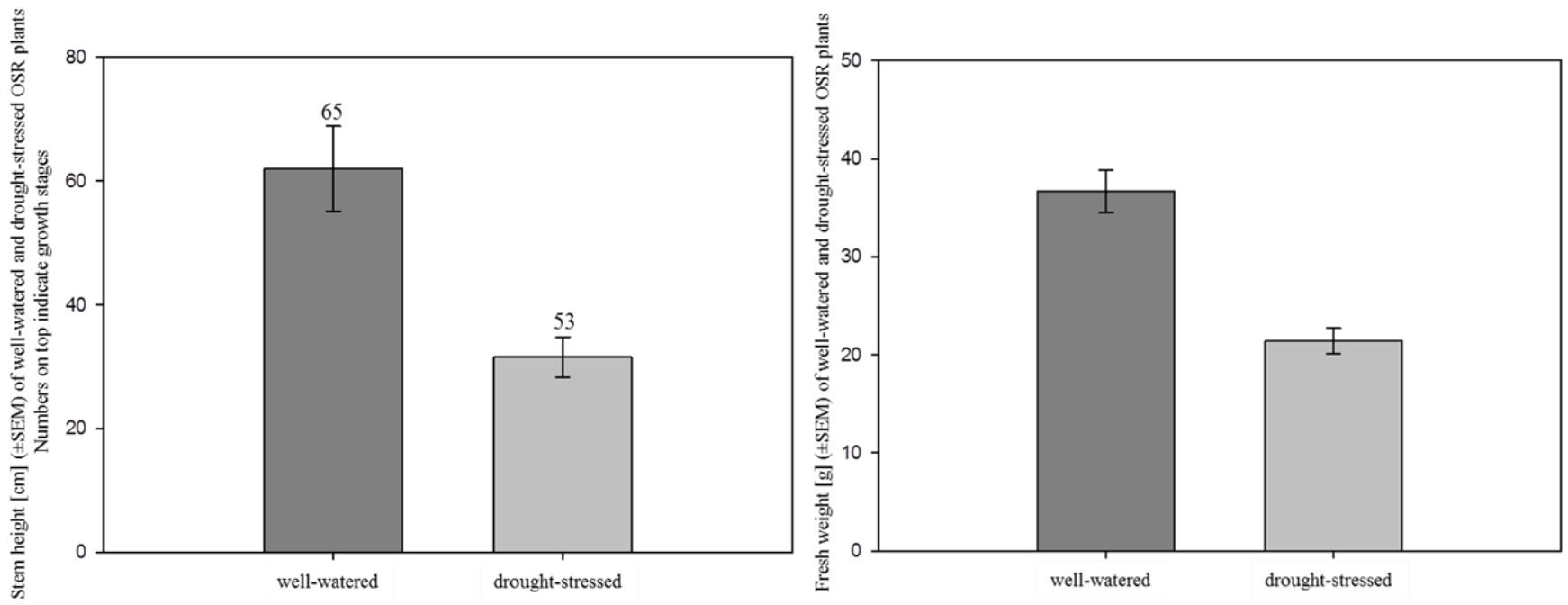

Figure 2. Stem height and fresh weight of well-watered and drought stressed plants

\section{Discussion}

The well-watered control plants emitted 27 compounds in total. Monoterpenes were the dominant compound class of VOCs collected. However, only two compounds significantly differed compared to the control plants. E-4,8-dimethyl-1,3,7-nonatriene and Methyl-2-ethyl hexanoate were induced by herbivory different to the profile of intact control plants. E-4,8-dimethyl-1,3,7-nonatriene was detected in both stress treatments, but was absent in the controls. All other compounds were similar to the stressed treatments. This study has in common with some other studies. Nonanal was found in the profile of damaged and undamaged plants (Boland et al., 1992; McEwan and MacFarlane Smith, 1998), and differed in their amounts only. In some studies, some compounds were even not emitted anymore through herbivory. The scents of Brassica flowers were dominated by $\beta$-pinene, sabinene, mycrene, limonene and $\beta$-phelandrene but disappeared in case of macerated plants (Tollsten and Bergström, 1988). Other studies detected an increase in $\alpha$-Pinene, $\beta$-Pinene and delta-3-carene from the bud stage to the flower stage (Veromann, 2013). This terpene group is therefore mostly present in the floral stages (Evans and Allen-Williams, 1992), but their emission may also be sent off the vegetative mass like our experiment showed. Comparable to former studies the sesquiterpene $\alpha$ farnesene was also collected from undamaged Brassica napus plants (Tollsten and Bergström, 1988). 
Therefore, we conclude that the concentration of the VOCs is more important for OSR than the VOCs themselves.

Some studies point out that mono- and dicotyledonous plants are different in their volatile response (Boland et al., 1992). Beside this, there are also tremendous changes in the VOC emission within one plant species caused by a range of environmental factors. Physiological changes like stress or pest infestation are reflected in the plant odor by emission rate and profile (Rani, 2012). These blends can be traced by phytophagous insects and their parasitoids for recognizing their hosts by a specific blend (Visser, 1986). The reaction of insect towards volatiles can be either attraction or repellence (Dicke and Loon, 2000). Some compounds result in a specific behavior, like allylisothiocyanate stimulates the oviposition of the diamondback moth (Thorsteinson, 1960).

In our study the release of herbivore-attacked plants did not differ in the VOC profile. The main difference was the increased amount of the same VOCs emitted by the intact control plants. Leaves normally release small quantities of VOCs; but when plants are damaged by herbivorous insects, additional volatiles are released (Paré and Tumlinson 1999, Dudareva et al., 2004) and the quantity is increased (McCloud and Baldwin, 1997; Vuorinen, 2004). The sesquiterpene group was represented by E,E - $\alpha$-farnesene but was not significantly different between the treatments. Contrary to Veromann (2013) who calculated a negative correlation between E,E - $\alpha$-farnesene and the damage caused by pollen beetles (Meligethes aeneus Fab.), we did not find an influence of the herbivore treatment on the amount of $E, E$ - $\alpha$-farnesene produced. $\beta$-farnesene is often regarded a VOC induced by herbivory (Paré and Tumlinson, 1999), which was also not found in our results. (E)-4,8-dimethyl-1,3,7nonatriene was often quantified in the headspaces of herbivore-infested plants and there is an assumption that this compound can allure predators (Boland et al., 1992). In our treatments, (E)-4,8dimethyl-1,3,7-nonatriene was dominant in the VOC profile of the stressed plant. It was ten times higher in the herbivore attacked than in drought stressed plants. Mechanical damage did, in most cases, not fully reflect the responses elicited by herbivory or oviposition. The response was induced by an herbivore-derived elicitor, like enzymes in the saliva (Boland et al., 1992). Methyl-2-ethyl hexanoate was only present in the herbivore attacked plants, so we regarded this as a more herbivore-induced component. Other studies referred to methyl-2-ethyl hexanoate as an ester. Esters are produced by autolytic oxidative breakdown of membrane lipids and are released when leaves are mechanically damaged (Paré and Tumlinson, 1999). All other compounds were either released by the control or the drought-stressed plants or both. Alcohols and aldehydes are mostly degradation products from leaf lipids (Tollsten and Bergström, 1988). In our plants alcohol was increased in the stress treatment, but the aldehyde nonanal was decreased by the herbivore attack and through drought stress. Some of the monoterpene and sesquiterpene, as well as indole and isomeric hexenyl butyrates and 2-methyl butyrates, were also only released from damaged leaves (Röse et al., 1996). Jasmonic acid and $\beta$ farnesene are often induced by herbivory but were not detected in our results (McCloud and Baldwin, 1997; Paré and Tumlinson, 1999). Some compounds were not found in our data. Different studies lacked to find similar compounds, even within the same plant species (Evans and Allen-Williams, 1992). Consistent performance of released compounds show that the same biosynthetic pathways are used by a wide range of plant families (Paré and Tumlinson, 1999). Other studies have proven that the same VOCs can be synthesized in plant species through different pathways (Dudareva et al., 2004). 
Cruciferous plants, such as $B$. napus, emit a complex mixture of VOCs; some of these are important cues in host selection by cruciferous pests and their parasitoids, aiding both finding and recognition of the host plant (Bartlet, 1993; Evans, 1998; Smart, 2000; Cook, 2006, Schiestl, 2010). In Brassicaceae, the most specific odor arises from the breakdown of secondary plant substances, like the formation of isothiocyanates from the non-volatile glucosinolates (Visser, 1986). Glucosinolates also stimulated feeding by aphids (Feeny, 1977). Glucosinolates are not always responsible for insect behavior. Ceutorhynchus assimilis performs a typical dose-response curve for 1,8-Cineole and Z-3-hexenyl acetate. The females are highly attracted by these compounds whereas males respond less (Blight et al., 1995). The different reactions of males and females to VOCs have also been reported by other researchers (Evans and Allen-Williams, 1992). Synergistic effects among the components of an odor blend were likely to contribute to the attractiveness of insects to plants. Other studies found out that there were differences in sensitivity of different populations (Visser, 1986). All plants emitted VOCs from insect-damaged leaves and even from leaves distal to the site of damage (Paré and Tumlinson, 1999). Plants can be induced by other plants to emit a herbivore-infested VOC blend which serve as a phytochemical signal between plant and insects (Blight et al., 1997; Paré and Tumlinson, 1999; Dicke and Loon, 2000). Insects discriminate between the blends of plants as shown in behavioral assays with Trichogramma japonicum. The egg parasitoid could distinguish among the blends of pestdamaged and pest-undamaged plants (Rani, 2012). Chemical volatiles induced by feeding larvae of ceutorhynchid weevils were attractive for parasitoid wasps (Alford, 2011). The results of bioassays indicated that the stem borer-infested rice plants emitted volatile chemicals through their stem surfaces, which are produced as a direct result of herbivory by the stem borer Scirpophaga incertulans (Rani, 2012).

VOC emissions during OSR growth were altered by drought stress compared to well-watered control plants. If plants are limited in their nutrient uptake, some components, which sometimes act as volatiles such as secondary metabolites, are not being produced (Veromann, 2013). We, therefore, initially hypothesized that stressed plants, which are less able to mobilize nutrients, emit fewer VOCs per gram fresh weight. This hypothesis was proven true for a number of compounds identified in this study. In contrast to other papers, however, we could not reveal that the control plants emitted the lowest amount of VOCs per gram fresh weight and drought stressed plants the highest amount of volatile emission per gram fresh weight. This corresponds with the findings of other studies, which describe that intact plants release lower rates of volatiles permanently (Röse et al., 1996). Based on studies with lima bean, drought stress also seems to directly affect VOC release (Takabayashi et al., 1994). Delta-3-carene may play a role in drought stress as the emission was intensified in our plants. Also alkanes were significantly increased with drought stress. Only 1-dodecene was significantly decreased in contrast to the control plants and the herbivore-infested plants. Nevertheless, the duration of stress is a relevant factor for the VOC emission (Hsiao, 1973). Moderate stress, for example, has no influence on the glucosinolate level of OSR plants (Jensen et al., 1996). The same stress in the vegetative phase caused an increase of glucosinolates and proteins but decreased the oil content of seeds built during the generative phase, also inhibiting the uptake of nutrients (Jensen et al., 1996). There were only two components -methyl salicylate and acetic acid - which had increased with higher nitrogen levels in OSR (Veromann, 2013). 
Another hypothesis was proven by our data as differences in the VOC profile of drought stressed plants and of herbivores attacked plants in contrast to the intact control plants were found. Since the emission of volatiles has previously been shown to be highly variable under different biotic and abiotic stresses (Holopainen and Gershenzon, 2010; Niinemets, 2010; Toome et al., 2010; Copolovici et al., 2011), the stress induced by herbivory or drought did not result in the same VOC profile. In all plant species, the major headspace volatile is either a green leaf volatile or a terpenoid (Paré and Tumlinson, 1999). In our study the main component was D/L-Limonene over all treatments. An undamaged plant maintains a baseline level of volatile metabolites that are released from the surface of the leaf and/or from accumulated storage sites in the leaf. These constitutive chemical reserves, which often include monoterpene, sesquiterpene, and aromatics, accumulate to high levels in specialized glands or trichomes (Paré and Tumlinson, 1999). In addition, green leaf odors consist of a blend of saturated and unsaturated six-carbon alcohols, aldehydes and esters (Paré and Tumlinson, 1999). Another group as terpenoids often occurs in plants as complex mixtures (Turlings and Tumlinson, 1992; Gershenzon, 1994). As a terpenoid only camphor was found in our plants, with a significant decrease for the herbivore attacked treatment. Comparatively Paré and Tumlinson (1999) findings corresponds to our profiles, as the monoterpene were almost equal, except that we additionally found sabinene, $\beta$-myrcene and $y$-terpinene. With less water available for the plant, elevated levels of VOCs were released from infested individual plants relative to drought stressed plants (Paré and Tumlinson, 1999). One compound, 4,8 dimethyl-1,3,7-nonatriene, is often found in injured tissue, but also in our drought stressed plants (Turlings and Tumlinson, 1992; Dudareva et al., 2004; Vuorinen, 2004). The levels of certain products in plants can have an impact on an insect's feeding on these plants (Smart and Blight, 1997). Herbivorous populations can be influenced positively or negatively depending on the stress level (Stavrinides et al., 2010). There are even different population dynamics with or without drought stress (Stavrinides et al., 2010).

Beside the VOC emission, drought stress had a large impact on plant height, thereby influencing the plant's growth stage and fresh weight, too. Often, the leaf growth is considered to be inhibited by drought stress (Hsiao, 1973; Chaves et al., 2003). This must be a general problem as stress often negatively influences growth and metabolism of plants (Richardson, 2012). The odor compositions reflect plant conditions and changes in plant age, plant physiological state and crop spacing, during the season (Visser, 1986). In our study the fact that the focus was not on the time when VOCs were released should be considered. One study found out that there are some volatiles emitted in rhythmic time intervals (Jakobsen et al., 1994), but the function of the compounds in the plants is still unknown and not fully understood. One hypothesis is that the plant uses the VOCs to allure predators to reduce negative effects of herbivory as an induced defense. On the other hand, the VOC can be attractive for pollinators. The differences in the VOC emission of our three treatments underline the importance to understand the complete ability of VOC production of OSR. Although we found no consistent pattern with regard to plant responses to either herbivore attack or drought stress, we highlighted that the interactions between these parameters has not been well addressed so far. Additional studies are needed which vary either the level of stress and/or herbivory, taking into account different OSR cultivars to better understand which VOCs are up- or down-regulated under which specific conditions. Moreover, the feeding damage of OSR herbivores may vary with the level of stress, and different 
Chapter 4

species, feeding either internally or externally, may result in different VOCs, both qualitatively and quantitatively. 


\section{References}

Alford DV (2011) Plant Pests. 1st edition. HarperCollins Publishers, London.

Bartlet E (1993). The responses of the cabbage stem weevil (Ceutorhynchus assimilis) to the odour of oilseed rape (Brassica napus) and to some volatile isothiocyanates. ENTOMOL EXP APPL. DOI: 10.1007/BF02380783.

Bartlet E (1996) Chemical Cues to Host-Plant Selection by Insect Pests of Oilseed Rape. Agricultural Zoology Reviews 7, 89-116.

Blight MM, Le Métayer M, Delègue MP, Pickett JA, Marion-Poll F, Wadhams LJ (1997) Identification of Floral Volatiles Involved in Recognition of Oilseed Rape Flowers, Brassica napus by Honeybees, Apis mellifera. J CHEM ECOL. DOI: 10.1023/B:JOEC.0000006446.21160.c1.

Blight MM, Pickett JA, Wadhams LJ, Woodcock CM (1995) Antennal perception of oilseed rape, Brassica napus (Brassicaceae), volatiles by the cabbage seed weevilCeutorhynchus assimilis (Coleoptera, Curculionidae). J CHEM ECOL. DOI: 10.1007/BF02033667.

Boland W, Feng Z, Donath J, Gäbler A (1992) Are acyclic C11 and C16 homoterpenes plant volatiles indicating herbivory? NATURWISSENSCHAFTEN. DOI: 10.1007/BF01140183.

Bray EA (2004) Genes commonly regulated by water-deficit stress in Arabidopsis thaliana. J EXP BOT. DOI: 10.1093/jxb/erh270.

Chaves MM, Maroco JP, Pereira JS (2003) Understanding plant responses to drought — from genes to the whole plant. FUNCT PLANT BIOL. DOI: 10.1071/FP02076.

Cook SM (2006) Exploitation of host plant preferences in pest management strategies for oilseed rape (Brassica napus). ENTOMOL EXP APPL 119, 221-229.

Cook SM, Khan ZR, Pickett JA (2007a) The Use of Push-Pull Strategies in Integrated Pest Management. ANNU REV ENTOMOL. DOI: 10.1146/annurev.ento.52.110405.091407.

Cook SM, Rasmussen HB, Birkett MA, Murray DA, Pye BJ, Watts NP, Williams IH (2007b) Behavioural and chemical ecology underlying the success of turnip rape (Brassica rapa) trap crops in protecting oilseed rape (Brassica napus) from the pollen beetle (Meligethes aeneus). ARTHROPODPLANT INTE. DOI: 10.1007/s11829-007-9004-5.

Copolovici L, Kännaste A, Remmel T, Vislap V, Niinemets Ü (2011) Volatile Emissions from Alnus glutionosa Induced by Herbivory are Quantitatively Related to the Extent of Damage. J CHEM ECOL. DOI: 10.1007/s10886-010-9897-9.

Dalin $\mathrm{P}$ (2011) Diapause induction and termination in a commonly univoltine leaf beetle (Phratora vulgatissima). INSECT SCI. DOI: 10.1111/j.1744-7917.2011.01417.x.

Dechert G, Ulber B (2004) Interactions between the stem-mining weevils Ceutorhynchus napi Gyll. and Ceutorhynchus pallidactylus (Marsh.) (Coleoptera: Curculionidae) in oilseed rape. AGR FOREST ENTOMOL. DOI: 10.1111/j.1461-9555.2004.00220.x.

Dicke M, Loon JJ (2000) Multitrophic effects of herbivore-induced plant volatiles in an evolutionary context. ENTOMOL EXP APPL. DOI: 10.1046/j.1570-7458.2000.00736.x.

Dudareva N, Pichersky E, Gershenzon J (2004) Biochemistry of Plant Volatiles. PLANT PHYSIOL 135, 1893-1902.

Eitzinger J, Orlandini S, Stefanski R, Naylor REL (2010) Climate change and agriculture: introductory editorial. J AGR SCI. DOI: 10.1017/s0021859610000481. 
Evans KA (1998) Response of Cabbage Seed Weevil (Ceutorhynchus assimilis) to Baits of Extracted and Synthetic Host-Plant Odor. J CHEM ECOL 24, 2101-2114.

Evans KA, Allen-Williams LJ (1992) Electroantennogram responses of the cabbage seed weevil,Ceutorhynchus assimilis, to oilseed rape,Brassica napus ssp.Oleifera, volatiles. J CHEM ECOL. DOI: 10.1007/BF00993236.

Feeny P (1977) Defensive Ecology of the Cruciferae. ANN MO BOT GARD 64, 221-234.

Gershenzon J (1994) Metabolic costs of terpenoid accumulation in higher plants. J CHEM ECOL. DOI: 10.1007/BF02059810.

Günthart E (1949) Beiträge zur Lebensweise und Bekämpfung von Ceuthorrhynchus quadriens PANZ. und Ceuthorrhynchus napi GYLL. mit Beobachtungen an weiteren Kohl- und Rapsschädlingen. Mitteilungen der Schweizerischen Entomologischen Gesellschaft 22, 441-591.

Gutierrez AP, Ponti L, d'Oultremont T, Ellis CK (2008) Climate change effects on poikilotherm tritrophic interactions. CLIMATIC CHANGE. DOI: 10.1007/s10584-007-9379-4.

Hansson BS, Larsson MC, Leal WS (1999) Green leaf volatile-detecting olfactory receptor neurones display very high sensitivity and specificity in a scarab beetle. PHYSIOL ENTOMOL. DOI: 10.1046/j.1365-3032.1999.00121.x.

Harte J, Torn M, Chang F, Feifarek B, Kinzig A, Shaw R, Shen K (1995) Global Warming and Soil Microclimate: Results from a Meadow-Warming Experiment. ECOL APPL 5, 132-150.

Holopainen JK, Gershenzon J (2010) Multiple stress factors and the emission of plant VOCs. TRENDS PLANT SCI. DOI: 10.1016/j.tplants.2010.01.006.

Hsiao, TC (1973) Plant Responses to Water Stress. ANNU REV PLANT PHYS. 24, 519-570.

Hsu J (1996) Multiple Comparisons: Theory and Methods. CRC Press.

IPCC (2012) Managing the risks of extreme events and disasters to advance climate change adaptation. Cambridge University Press, New York.

Jakobsen HB, Friis P, Nielsen JK, Olsen CE (1994) Emission of volatiles from flowers and leaves of Brassica napus in situ. PHYTOCHEMISTRY. DOI: 10.1016/S0031-9422(00)90341-8.

Jalali MA, Tirry L, Clercq P (2010) Effect of temperature on the functional response of Adalia bipunctata to Myzus persicae. BIOCONTROL. DOI: 10.1007/s10526-009-9237-6.

Jensen C, Mogensen V, Mortensen G, Fieldsend J, Milford G, Andersen M, Thage J (1996) Seed glucosinolate, oil and protein contents of field-grown rape (Brassica napus L.) affected by soil drying and evaporative demand. FIELD CROP RES. DOI: 10.1016/0378-4290(96)00026-3.

Juran I, Gotlin Culjak T, Grubisic D (2011) Rape Stem Weevil (Ceutorhynchus napi Gyll. 1837) and Cabbage Stem Weevil (Ceutorhynchus pallidactylus Marsh. 1802) (Coleoptera: Curculionidae) Important Oilseed Rape Pests. Agriculturae Conspectus Scientificus 76, 93-100.

Karl TR, Trenberth KE (2003) Modern Global Climate Change. SCIENCE. DOI: 10.1126/science.1090228.

Lancashire PD, Bleiholder H, van Boom TD, Langelüddeke P, Stauss R, Weber E, Witzenberger A (1991) A uniform decimal code for growth stages of crops and weeds. ANN APPL BIOL. DOI: 10.1111/j.1744-7348.1991.tb04895.x.

Maarse H, Kepner RE (1970) Changes in composition of volatile terpenes in Douglas fir needles during maturation. J AGR FOOD CHEM. DOI: 10.1021/jf60172a007. 
Marazzi C, Patrian B, Städler E (2004) Secondary metabolites of the leaf surface affected by sulphur fertilisation and perceived by the diamondback moth. CHEMOECOLOGY. DOI: 10.1007/s00049-0030264-y.

Marazzi C, Städler E (2004) Arabidopsis thaliana leaf-surface extracts are detected by the cabbage root fly (Delia radicum) and stimulate oviposition. PHYSIOL ENTOMOL. DOI: 10.1111/j.03076962.2004.00384.x.

Mattiacci L, Dicke M, Posthumus MA (1995) beta-Glucosidase: an elicitor of herbivore-induced plant odor that attracts host-searching parasitic wasps. P NATL ACAD SCI USA 6, 2036-2040.

Mattson W, Haack RA (1987) The Role of Drought in Outbreaks of Plant-Eating Insects. BIOSCIENCE 37, 110-118.

McCloud ES, Baldwin IT (1997) Herbivory and caterpillar regurgitants amplify the wound-induced increases in jasmonic acid but not nicotine in Nicotiana sylvestris. PLANTA. DOI: $10.1007 / \mathrm{s} 004250050210$.

McEwan M, MacFarlane Smith WH (1998) Identification of volatile organic compounds emitted in the field by oilseed rape (Brassica napus ssp. oleifera) over the growing season. CLIN EXP ALLERGY. DOI: 10.1046/j.1365-2222.1998.00234.x.

Niinemets Ü (2010) Mild versus severe stress and BVOCs: thresholds, priming and consequences. TRENDS PLANT SCI. DOI: 10.1016/j.tplants.2009.11.008.

Paré P, Tumlinson J (1999) Plant Volatiles as a Defense against Insect Herbivores. PLANT PHYSIOL $121,325-332$.

Peterson RKD, Davis RS, Higley LG, Fernandes OA (2009) Mortality risk in insects. ENVIRON ENTOMOL. DOI: 10.1603/022.038.0102.

Qaderi MM, Kurepin LV, Reid DM (2006) Growth and physiological responses of canola (Brassica napus) to three components of global climate change: temperature, carbon dioxide and drought. PHYSIOL PLANTARUM. DOI: 10.1111/j.1399-3054.2006.00804.x.

Rani PU, Sandhyarani K (2012) Specificity of systemically released rice stem volatiles on egg parasitoid, Trichogramma japonicum Ashmead behaviour. J APPL ENTOMOL. DOI: 10.1111/j.14390418.2012.01705.x.

Richardson ML (2012) Temperature influences the expression of resistance of soybean (Glycine max ) to the soybean aphid (Aphis glycines ). J APPL ENTOMOL. DOI: 10.1111/j.1439-0418.2011.01692.x.

Röse U, Manukian A, Heath RR, Tumlinson JH (1996) Volatile Semiochemicals Released from Undamaged Cotton Leaves (A Systemic Response of Living Plants to Caterpillar Damage). PLANT PHYSIOL 111, 487-495.

Schiestl FP (2010) The evolution of floral scent and insect chemical communication. ECOL LETT. DOI: 10.1111/j.1461-0248.2010.01451.x.

Smart LE, Blight MM (1997) Field Discrimination of Oilseed Rape, Brassica napus Volatiles by Cabbage Seed Weevil, Ceutorhynchus assimilis. J CHEM ECOL. DOI: 10.1023/B:JOEC.0000006666.77111.ab.

Smart LE, Blight MM (2000) Response of the Pollen Beetle, Meligethes aeneus, to Traps Baited with Volatiles from Oilseed Rape, Brassica napus. J CHEM ECOL. DOI: 10.1023/A:1005493100165.

Stavrinides MC, Daane KM, Lampinen BD, Mills NJ (2010) Plant Water Stress, Leaf Temperature, and Spider Mite (Acari: Tetranychidae) Outbreaks in California Vineyards. ENVIRON ENTOMOL. DOI: 10.1603/EN09288. 
Steinbauer MJ, Kriticos DJ, Lukacs Z, Clarke AR (2004) Modelling a forest lepidopteran: phenological plasticity determines voltinism which influences population dynamics. FOREST ECOL MANAG. DOI: 10.1016/j.foreco.2004.03.041.

Takabayashi J, Dicke M, Posthumus MA (1994) Volatile herbivore-induced terpenoids in plant-mite interactions: Variation caused by biotic and abiotic factors. J CHEM ECOL. DOI:

10.1007/BF02059811.

Tholl D, Boland W, Hansel A, Loreto F, Röse U, Schnitzler J (2006) Practical approaches to plant volatile analysis. PLANT J. DOI: 10.1111/j.1365-313X.2005.02612.x.

Thorsteinson AJ (1960) Host Selection in Phytophagous Insects. ANNU REV ENTOMOL. DOI: 10.1146/annurev.en.05.010160.001205.

Tollsten L, Bergström G (1988) Headspace volatiles of whole plants and macerated plant parts of Brassica and Sinapis. PHYTOCHEMISTRY. DOI: 10.1016/0031-9422(88)83085-1.

Toome M, Randjärv P, Copolovici L, Niinemets Ü, Heinsoo K, Luik A, Noe SM (2010) Leaf rust induced volatile organic compounds signalling in willow during the infection. PLANTA. DOI: $10.1007 / \mathrm{s} 00425-010-1169-\mathrm{y}$.

Turlings TC, Tumlinson JH (1992) Systemic release of chemical signals by herbivore-injured corn. $\mathrm{P}$ NATL ACAD SCI USA 89, 8399-8402.

Venables WN, Ripley BD (1997) Modern applied statistics with S-Plus. 2nd edition. Springer, New York.

Veromann E (2013) Effects of nitrogen fertilization on insect pests, their parasitoids, plant diseases and volatile organic compounds in Brassica napus. CROP PROT 43, 79-88.

Visser JH (1986) Host Odor Perception in Phytophagous Insects. ANNU REV ENTOMOL. DOI: 10.1146/annurev.en.31.010186.001005.

Vuorinen T (2004) Monoterpene and herbivore-induced emissions from cabbage plants grown at elevated atmospheric CO2 concentration. ATMOS ENVIRON. DOI: 10.1016/j.atmosenv.2003.10.029.

Weissteiner S, Huetteroth W, Kollmann M, Weißbecker B, Romani R, Schachtner J, Schütz S, MarionPoll F, 2012. Cockchafer Larvae Smell Host Root Scents in Soil. PLOS ONE. DOI:

10.1371/journal.pone.0045827. 


\section{General discussion}

In the next decades, the climate will change. As temperature is considered as the most important environmental factor affecting insect distribution, development, behavior, survival and reproduction (Bale et al., 2002), the climate change might also alter the impact of insects on their host plants. This is an interesting point due to the competition between insect pests and humans for crops (Lamb, 1989) by reducing the yield for human nutrition by these insects. Recently, the number of studies investigating the influence of a changing climate on insect pests and their host plants increased. However, studies about the interaction between the rape stem weevils (RSW) and its host winter oilseed rape (WOSR) are still missing.

This thesis aimed at complementing the results of an ongoing research of the interaction between WOSR and RSW. Therefore, different methods were used to study the influence of an increased temperature on different life stages of RSW and WOSR. Moreover, the volatile emission of drought stressed WOSR plants was determined. Specifically, we investigated the phenology of WOSR and the infestation dynamic of RSW (chapter 1). We further analyzed the impact of an increased soil temperature on WOSR growth and RSW infestation as well as the adult emergence (chapter 2). In addition, two experiments were conducted to analyze the interaction between WOSR and RSW with regard to an increased temperature (chapter $3+4$ ). All investigations were carried out based on the research framework "KLIFF - Climate Impact and Adaption Research in Lower Saxony". To the best of our knowledge, this is the first study about the influence of climate change on RSW, WOSR and their interaction performed in field, semi-field and laboratory trials.

\section{Effect of phenology of WOSR plants on the RSW infestation}

Across all experiments, the influence of temperature has been considered as the most important factor influencing the interaction between RSW and its host. The temperature should have an effect on the growth stage of the plant (Eitzinger et al., 2010). As insects are depending on the growth stage of WOSR as well as on climatic conditions (Williams and Carden, 1961; Koubaiti and Lerin, 1992), we assumed a higher infestation rate of the earlier developed variety in this field experiment (chapter 1). This was only confirmed for the first sampling dates by the data set. Finally, the late variety was more affected by the infestation of RSW. One reason might be that the abundance of RSW larvae was relatively high during the experimental time.

To test the impact of damage potential of RSW on WOSR, we calculated the indices "stem injury index" and "damage index". Both indices depend on the length of the plants. They are good estimates for the damage potential to compare plants at a definite time. The stem injury index was introduced by Eickermann et al. (2011), but they used only one sampling date to proof this index. Thus, the index was not verified for data sets at regular intervals.

Another important point is the nutrition status of the plants. This status played a role on the damage potential of pollen beetles (Rusch et al., 2013). This is consistent with a study of Veromann et al. (2013). They found that the damage of pollen beetles and the cabbage seed pod weevil is linked to the $\mathrm{N}$ fertilization of the WOSR (Veromann, 2013).

\section{Effect of temperature on WOSR pants and RSW}

So far, the biology of the RSW and its interaction with WOSR is not completely known. In chapter 2, we investigated the influence of a soil warming experiment. We observed a significant impact of 
increase of soil temperature 2 or $4^{\circ} \mathrm{C}$ on WOSR in spring. This is consistent with the theory that plants are also responding to climate warming (Westwood and Blair, 2010). For example, there are negative effects on olive orchards predicted for Southern California. This is caused by mild winters when the required vernalization of the olive trees cannot happen (Gutierrez et al., 2008).

Climate change altered significantly the life stages of WOSR. A temperature increase of only a few degrees Celsius will result in an extended period of plant vegetation by a few weeks (Weigel, 2005). Consequently, the distribution of the plant can change which might result in an altered distribution of its associated herbivores. Unlike plant species, insects such as butterflies may respond quite quickly to climate fluctuations (Westwood and Blair, 2010).

In this thesis, a temperature related impact was more sensitive on RSW than on plants. The adult emergence was increased with an additional $2^{\circ} \mathrm{C}$ soil temperature. This result is analogous to Westwood and Blair (2010). They showed that butterflies emerged earlier in the Canadian forest over the last decades. On the other hand, with a $2^{\circ}$ and $3^{\circ} \mathrm{C}$ increase in average daily temperatures, the geographic distribution of the mealybug across California remains relatively unchanged (Gutierrez et al., 2008). According to Gregory et al. (2009), the climate alone does not determine the distribution of a species.

Different WOSR varieties did not significantly differ on RSW population dynamics which confirms results by a previous study (Koubaiti and Lerin, 1992; Büchi, 1996). The growth stage development was more important on host selection than the variety (Koubaiti and Lerin, 1992). The variety with a more advanced growth stages was heavier infested by the RSW. This is consistent with Rusch et al. (2013).

\section{Laboratory trial}

Moreover, we observed an effect of temperature on the oviposition of RSW. This is in accordance with the results of other studies (Günthart, 1949; Alford, 2011), even for other insects (Hagstrum and Hagstrum, 1970; Hagstrum and Leach, 1973; Behrens et al., 1983; Wilstermann and Vidal, 2013). In our study, the impact of a constant compared to a varying temperature regime was significant. The plants used in this experiment had the same growth stage to avoid artifacts caused by the growth stage which is mainly responsible for the oviposition (Koubaiti and Lerin, 1992). It would be interesting to complete our data with future studies to obtain a complete life table for RSW. Many insects develop very slowly at the start of the season, when field temperatures are little higher than the threshold (Gilbert and Raworth, 1996). Consequently, the egg development can be very variable from year to year. Another point is that the Kaufmann effect was disregarded in our study. The Kaufmann effect leads to an increase in growth speed in the lower temperature range, but to a decrease in the upper range (Behrens et al., 1983).

It is well-known that the development under sub-optimal temperature can have important consequences on the fitness of the resulting adult insect (Lessard and Boivin, 2013). The longevity of adults was expected to be elongated at lower temperatures, as already shown in other studies (Behrens et al., 1983; Bayhan et al., 2006; Jaramillo et al., 2009). Low temperature, however, can lead to different dysfunctions with increased fitness costs (Lessard and Boivin, 2013) and may also reduce the longevity of RSW adults. Our data set showed no differences in the life span of RSW at different temperatures. 


\section{Impact of drought stress on oilseed rape plants and rape stem weevils}

There are still huge knowledge gaps about the chemical interactions between plants and insect herbivores which can lead to changes in synthesis and release of volatiles by the plants (Paré and Tumlinson, 1999). As the selection of the host plant by ovipositing females may be the most critical stage for limiting the host range (Smith and Beck, 2013), females should be used in these tests (Röttger, 1978/79; Evans and Allen-Williams, 1992). The last chapter of this thesis was addressed to the VOC emission of OSR plants and a behavioral test with RSW.

In general agreement with previous work, the time when VOC emission is detected, is important (Cole, 1980; Lamb, 1989). There is a several hour delay between the beginning of herbivore damage and the release of induced VOCs (Dudareva et al., 2004). Mechanical damage causes immediate changes of VOC emission, but herbivore-induced changes can appear after 2-4 hours (Paré and Tumlinson, 1999; Smith and Beck, 2013). In our trial, the VOC emission was detected 48 hours after the beginning of the feeding tests, so that emission should be recorded during the whole experiment. This must be regarded in future trials.

\section{Effect of drought on OSR plants}

In chapter 4, we observed that the plants are slow down in their growth stage if drought stress occurs. Drought stress is already known for its responsibility for a growth reduction. Drought stress causes specific changes similar to changes induced by nutrient deficiencies (Hsiao, 1973). The effect of drought on OSR plants was clearly visible during the experiment. Drought-stressed plants showed the symptoms of wilting during the whole experiment. The stunted growth lead to the fact that stressed plants produce less straw and less pods with fewer seeds (Jensen et al., 1996). Similar results are presented in our study: the fresh weight was reduced.

The effect of drought stressed plants on RSW larvae was not tested in our trial. As stressed plants are less provided with nutrients, this may result in a negative effect for the insect development. Ohnesorge (1991) described that a critical shortage of nutrition can have negative effects on the next generation of insects (Ohnesorge, 1991). Moreover, the water content of the plant tissue is positively correlated to larval growth (Coley, 1983) and therefore can have a positive effect on the larval development.

\section{Future development}

Each organism will be affected differentially by the climate change (Gutierrez et al., 2008). Thus, data should be regarded carefully when extrapolating results of insect-plant relations from greenhouse experiments to natural situations. Most models have been developed with limited data, often from a single location, and may not hold at other locations. An important issue when considering adaptations of insects to climate change is the imprecise prediction of the future climate. As consequence, smaller intervals in the temperature regimes should be used in future studies.

To assess the interaction between RSW females and the VOC emission of WOSR, the attraction of insects to plants could be tested in a flight tunnel or an olfactometer. Furthermore the larval development on drought stressed plants is missing. Such an approach could answer the question if larvae are able to survive in stressed plants induced by a changing climate. Further trials could include infested WOSR plants with mining RSW larvae compared to uninfested plants. It would be interesting to see whether RSW females are able to discriminate between infested and uninfested plants. Another 
study has shown that internal feeding is hard to observe in plants (Rani and Sandhyarani, 2012), but the VOC emission can give an indication for botanical changes. 


\section{References General introduction and discussion}

Alford DV, 2011. Plant Pests. 1st edition. HarperCollins Publishers, London.

Bale JS, Masters GJ, Hodkinson ID, Awmack C, Bezemer TM, Brown VK, Butterfield J, Buse A, Coulson JC, Farrar J, Good J. E. G., Harrington R, Hartley S, Jones TH, Lindroth RL, Press MC, Symrnioudis I, Watt AD, Whittaker JB, 2002. Herbivory in global climate change research: direct effects of rising temperature on insect herbivores. Global Change Biol 8, 1-16. DOI: 10.1046/j.1365-2486.2002.00451.x.

Behrens W, Hoffmann K, Kempa S, Gäßler S, Merkel-Wallner G, 1983. Effects of diurnal thermoperiods and quickly oscillating temperatures on the development and reproduction of crickets, Gryllus bimaculatus. Oecologia 59, 279-287. DOI: 10.1007/BF00378849.

Blight MM, Le Métayer M, Delègue MP, Pickett JA, Marion-Poll F, Wadhams LJ, 1997. Identification of Floral Volatiles Involved in Recognition of Oilseed Rape Flowers, Brassica napus by Honeybees, Apis mellifera. J Chem Ecol 23, 1715-1727. DOI: 10.1023/B:JOEC.0000006446.21160.c1.

Boer JG de, Posthumus MA, Dicke M, 2004. Identification of Volatiles That Are Used in Discrimination Between Plants Infested with Prey or Nonprey Herbivores by a Predatory Mite. J Chem Ecol 30, 2215-2230. DOI: 10.1023/B:JOEC.0000048784.79031.5e.

Büchi R, 1996. Eiablage des RapsstengelrüßlersCeutorhynchus napi Gyll., in Abhängigkeit der Stengellänge bei verschiedenen Rapssorten. Anzeiger für Schädlingskunde, Pflanzenschutz, Umweltschutz 69, 136-139. DOI: 10.1007/BF01904715.

Cole RA, 1980. Volatile components produced during ontogeny of some cultivated crucifers. J. Sci. Food Agric. 31, 549-557. DOI: 10.1002/jsfa.2740310606.

Dicke M, Loon JJ, 2000. Multitrophic effects of herbivore-induced plant volatiles in an evolutionary context. Entomologia Experimentalis et Applicata 97, 237-249. DOI: 10.1046/j.15707458.2000.00736.x.

Dudareva N, Pichersky E, Gershenzon J, 2004. Biochemistry of Plant Volatiles. Plant Physiology 135, 1893-1902.

Eickermann M, Ulber B, Vidal S, 2011. Resynthesized lines and cultivars of Brassica napus L. provide sources of resistance to the cabbage stem weevil (Ceutorhynchus pallidactylus (Mrsh.)). Bull. Entomol. Res. 101, 287-294. DOI: 10.1017/S0007485310000489.

Eickermann M, Beyer M, Goergen K, Hoffmann L, Junk J, others, 2014. Shifted migration of the rape stem weevil Ceutorhynchus napi (Coleoptera: Curculionidae) linked to climate change. European Journal of Entomology 111, 243-250.

Eitzinger J, Orlandini S, Stefanski R, Naylor REL, 2010. Climate change and agriculture: introductory editorial. J. Agric. Sci. 148, 499-500. DOI: 10.1017/s0021859610000481.

Finch S, 1978. Volatile plant chemicals and their effect on host plant finding by the cabbage root fly (Delia brassicae). Influence des Substances Chimiques Volatiles dur la Decouverte des Plantes Hotes par la Mouche du Chou (Delia brassica). Entomologia Experimentalis et Applicata 24, 350359. DOI: 10.1007/BF02385085.

Gerard PJ, Barringer JRF, Charles JG, Fowler SV, Kean JM, Phillips CB, Tait AB, Walker GP, 2013. Potential effects of climate change on biological control systems: case studies from New Zealand. Biocontrol 58, 149-162. DOI: 10.1007/s10526-012-9480-0.

Günthart E, 1949. Beiträge zur Lebensweise und Bekämpfung von Ceuthorrhynchus quadriens PANZ. und Ceuthorrhynchus napi GYLL. mit Beobachtungen an weiteren Kohl- und Rapsschädlingen. Mitteilungen der Schweizerischen Entomologischen Gesellschaft 22, 441-591. 
Gutierrez AP, Ponti L, d'Oultremont T, Ellis CK, 2008. Climate change effects on poikilotherm tritrophic interactions. Climatic Change 87, 167-192. DOI: 10.1007/s10584-007-9379-4.

Haberlandt U, Belli A, Hölscher J, 2010. Trends in beobachteten Zeitreihen von Temperatur und Niederschlag in Niedersachsen. Hydrologie und Wasserbewirtschaftung 54, 28.

Hagstrum DW, Hagstrum WR, 1970. A Simple Device for Producing Fluctuating Temperatures, with an Evaluation of the Ecological Significance of Fluctuating Temperatures. Annals of the Entomological Society of America 63, 1385-1389.

Hagstrum DW, Leach CE, 1973. Role of Constant and Fluctuating Temperatures in Determining Development Time and Fecundity of Three Species of Stored-Products Coleoptera. Annals of the Entomological Society of America 66, 407-410.

Holopainen JK, Gershenzon J, 2010. Multiple stress factors and the emission of plant VOCs. Trends in Plant Science 15, 176-184. DOI: 10.1016/j.tplants.2010.01.006.

Keena MA, Moore PM, 2010. Effects of Temperature on Anoplophora glabripennis. Environmental Entomology 39, 1323-1335. DOI: 10.1603/EN09369.

Klimaschutz R, 2012. Empfehlung für eine niedersächsische Strategie zur Anpassung an die Folgen des Klimawandels.Niedersächsisches Ministerium für Umwelt, Energie und Klimaschutz, 113 pp., Hannover.

Kocmankova E, Trnka M, Eitzinger J, Dubrovsky M, Štepanek P, Semeradova D, Balek J, Skalak P, Farda A, Juroch J, Žalud Z, 2011. Estimating the impact of climate change on the occurrence of selected pests at a high spatial resolution: a novel approach. The Journal of Agricultural Science 149, 185-195. DOI: 10.1017/S0021859610001140.

Koubaiti K, Lerin J, 1992. Fecundity and egg laying dynamics of Baris coerulescens Scop. (Col., Curculionidae) on oilseed rape. Journal of Applied Entomology 114, 289-297. DOI: 10.1111/j.1439-0418.1992.tb01129.x.

Lamb RJ, 1989. Entomology of Oilseed Brassica Crops. Annu. Rev. Entomol. 34, 211-229. DOI: 10.1146/annurev.en.34.010189.001235.

Rani PU, Sandhyarani K, 2012. Specificity of systemically released rice stem volatiles on egg parasitoid, Trichogramma japonicum Ashmead behaviour. Journal of Applied Entomology 136, 749-760. DOI: 10.1111/j.1439-0418.2012.01705.x.

Rusch A, Valantin-Morison M, Sarthou J, Roger-Estrade J, 2013. Effect of crop management and landscape context on insect pest populations and crop damage. Agriculture, Ecosystems \& Environment 166, 118-125. DOI: 10.1016/j.agee.2011.05.004.

Paré P, Tumlinson J, 1999. Plant Volatiles as a Defense against Insect Herbivores. Plant Physiology 121, 325-332.

Simpson RF, McQuilkin RM, 1976. Identification of volatiles from felled Pinus radiata and the electroantennograms they elicit from Sirex noctilio. Entomologia Experimentalis et Applicata 19, 205-213. DOI: 10.1007/BF00302055.

Takabayashi J, Dicke M, Posthumus MA, 1994. Volatile herbivore-induced terpenoids in plant-mite interactions: Variation caused by biotic and abiotic factors. J Chem Ecol 20, 1329-1354. DOI: 10.1007/BF02059811.

Veromann E, 2013. Effects of nitrogen fertilization on insect pests, their parasitoids, plant diseases and volatile organic compounds in Brassica napus. Crop Protection 43, 79-88.

Visser JH, 1986. Host Odor Perception in Phytophagous Insects. Annu. Rev. Entomol. 31, 121-144. DOI: 10.1146/annurev.en.31.010186.001005. 
Westwood AR, Blair D, 2010. Effect of regional climate warming on the phenology of butterflies in boreal forests in Manitoba, Canada. Environ. Entomol. 39, 1122-1133. DOI: 10.1603/EN09143.

Wigley TML, Raper SCB, 2001. Interpretation of High Projections for Global-Mean Warming. Science 293, 451-454. DOI: 10.1126/science.1061604.

Williams JJW, Carden PW, 1961. Cabbage Stem Flea Beetle in East Anglia. Plant Pathology 10, 8595. DOI: 10.1111/j.1365-3059.1961.tb00124.x.

Wilstermann A, Vidal S, 2013. Western corn rootworm egg hatch and larval development under constant and varying temperatures. J Pest Sci, 1-10. DOI: 10.1007/s10340-013-0496-8. 


\section{Zusammenfassung}

Raps (Brassica napus L.) ist die bedeutendste Ölpflanze in Deutschland. Der Ertrag wird jährlich durch den Befall von Schädlingen bedroht. Zum Einsatz kommen im konventionellen Anbau verschiedene Insektizide. Der Befall mit Rapsstängelrüsslern (Ceutorhynchus napi GYLL.) kann bis zu $70 \%$ Minderertrag zur Folge haben. Entscheidend für die Ausprägung des Schadens ist der Vorgang der Eiablage. Mit der Eiablage gibt das Weibchen ein Sekret ab, welches das Stängelmark schädigt und die charakteristischen Symptome hervorruft. Die Symptome sind Stauchung der Pflanzen, verdrehte und aufgeplatzte Stängel. Die Wunden können Eintrittspforten für pilzliche Erreger sein. Die Eier bzw. Larven, die im Stängel schlüpfen und sich vom Stängelmark ernähren, sind mit konventionellen Insektizidbehandlungen nicht erreichbar. Der Schaden durch erwachsene Tiere ist, abgesehen von der Eiablage, unerheblich. Im Hinblick auf die Biologie von Insekten sind die Temperatureinflüsse von außen maßgeblich. Für den Klimawandel wird eine Erwärmung für Niedersachsen vorhergesagt von $2^{\circ} \mathrm{C}$ für die nahe Zukunft und $4^{\circ} \mathrm{C}$ für den Zeitraum $2070-2100$.

Ziel dieser Studie war es mit verschiedenen Versuchen den Einfluss des Klimawandels auf die Schädling-Pflanzen Beziehung zu benennen. Dazu gehörte ein Feldversuch, der angesetzt wurde um die Ausprägung des Schadens durch den Rapsstängelrüssler an zwei verschiedenen Sorten zu vergleichen. Des Weiteren wurde untersucht wie sich eine erhöhte Bodentemperatur auf die Wirtspflanze und deren natürlicher Befall sowie das Schlupfen der erwachsenen Rüssler auswirkt. Im Labor wurden die Eiablage, die Lebensdauer und die Fertilität erwachsener Weibchen unter Einfluss unterschiedlicher Temperaturen beobachtet. Im Zuge des Klimawandels wird sich neben der Temperatur auch die Regenverteilung verändern. Deshalb befasste sich abschließend ein Versuch mit der Auswirkung von Trockenstress auf das Duftstoffspektrum von Raps.

Die Ergebnisse dieser Studie sind ebenso vielfältig wie die Versuche selbst. Der Feldversuch hat keine Unterschiede des Befalls zwischen zwei Sorten gezeigt. Im Frühjahr bevorzugten die RSR die frühe Sorte und wechselten später auf die späte Sorte. Eindeutige Präferenzen waren nicht erkennbar. Indikatoren für die Ausprägung des Schadens kristallisierten sich nicht heraus.

Innerhalb der Göttinger Bodenerwärmungsanlage wurde deutlich, dass die Erhöhung der Bodentemperatur auf $2^{\circ} \mathrm{C}$ und $4^{\circ} \mathrm{C}$ einen signifikanten Einfluss auf das Wachstum der Rapsplanzen hatte. Dies spiegelte sich auch in den Befallshäufigkeiten wieder. Die großen Pflanzen aus den erwärmten Bereichen wurden zur Eiablage der weiblichen Rapsstängelrüssler bevorzugt. In den erwärmten Bereichen wurden auch eine Woche früher $50 \%$ des Schlupf der Erwachsenen erreicht.

Die Eiablage ist temperaturabhängig. Je höher die Temperatur ist, desto signifikant mehr Eier werden gelegt. Es wurde ein Unterschied deutlich im Temperaturbedürfnis des Ei-Schlupf und in der Mortalitätsrate, ob die Temperatur gleichförmig oder wechselnd auf die Eier einwirkt. Die Fertilität und die Lebensdauer der erwachsenen Weibchen wurden nicht von der Temperatur beeinflusst.

Trockenstress verändert das Duftstoffspektrum von Rapspflanzen. Es gibt Unterschiede in der Zusammensetzung der Duftstoffprofile und in der Intensität der abgegebenen Stoffe. Diese werden verändert durch den Trockenstress sowohl als auch durch den Fraß der erwachsenen Rüsslern.

Diese Versuche waren der Anfang für die Erforschung des Klimawandels am Beispiel der Interaktion zwischen Raps und Rapsstängelrüsslers. Abschließend müssen weitere Versuche den komplexen Einfluss des Klimawandels auf dieser Beziehung klären. 


\section{Danksagung}

Herrn Prof. Dr. Vidal danke ich für die Aufnahme in seine Arbeitsgruppe und seine konstruktiven Kritikäußerungen.

Herrn Prof. Dr. von Tiedemann möchte ich danke für die Mitarbeit an der Göttinger Bodenerwärmungsanlage.

Herrn Prof. Dr. Schütz und Dr. von Fragstein und Niemsdorff danke ich für die Möglichkeit der Headspaceanalyse und Auswertung in ihrem Labor.

Herr Dr. Ulber danke ich für die Betreuung meines Projektes.

Herrn Reinke danke ich für die technische Begleitung der Feldversuche und die gute fachliche Betreuung der Göttinger Bodenerwärmungsanlage, an der ebenso beteiligt waren Herr Gremmes und Herr Fiebrich.

Ein großes Dankeschön an Dr. Mario Schumann, Dr. Ines Vollhardt, Dr. Maximilian von Fragstein und Niemsdorff und Dr. Magdalena Siebold für die Bereitschaft meine Arbeit Korrektur zu lesen.

A big thanks goes to my sister-in-law Ezra Gilbody for proof reading my English.

Vielen Dank an Christine Rachow für die Abbildung der lonenchromatogramme.

Ein herzliches Dankeschön geht nach Gießen an Dr. Eileen Knorr und Dr. Torsten Will für die Sigma Plot-Mitbenutzung.

Ein ganz großes Dankeschön geht an die entomologische Abteilung: an Doro für jede fachliche und menschliche Ermunterung, an Bianca für fachliche und argumentative Gespräche, an die

Statistikcracks Anne und Lana, an Alex und Henrike für landwirtschaftliches Know-How, an Christina für geistliche Unterstützung, an Helge für's Helge-Sein, an Mario (und Steffi) für's Dasein, an MarieLuise für das Zeigen von vielen Dingen, an Sandra für das Ausüben der gemeinsamen Hobbies, to Leilei for being her and for her cooking, an Katharina für's Reden, an Maggie und Kerstin für die tolle Zusammenarbeit als Doktorandensprecherinnen, an Mark für den Diskofox und vor allen Dingen an alle Kollegen, aus denen Freunde wurden.

An die technische Hilfe der Auszubildenden Jacqueline Platzek, Isabella Lubig, Sarah Heppner, Daniel Kretzschmar und Marian Süß. Und dem ganzen Fachbereich Pflanzenschutz und Phytopathologie danke ich für die tolle Zeit in Göttingen.

Mein herzlichster Dank für seine Liebe, Geduld, Verständnis und Hartnäckigkeit geht an den Mann, den ich gegen keinen anderen eintauschen möchte, meinen Björn.

Ich danke Madita Averdunk, Robert Hegemann, Britta Runkel, Isabel Kiene, Judith Besseling und Carolin Bertels für die nette Göttinger Wohngemeinschaft.

Ein besonderer Dank geht an meine Familie für Unterstützungen aller Art.

An alle Freunde, die nach so langer Entbehrung immer noch da sind. 


\section{Curriculum vitae}

Antje Reinhardt

Date of birth July $7^{\text {th }}, 1982$

Place of birth Gießen (Germany)

06/2002

Goethe - Schule Wetzlar, final exam: "Allgermeine Hochschulreife"

10/2002 - 10/2006 studies in agricultural sciences at the Justus-Liebig-University of Gießen, final exam : Bachelor of Science

$10 / 2006-01 / 2010$

studies in agricultural sciences at the Justus-Liebig-University of Gießen, final exam : Master of Science

Since $03 / 2010$ Ph. D. student at the Georg-August-University, Göttingen, Department of Crop Sciences, Division of Agricultural Entomology 


\section{Erklärungen}

1. Hiermit erkläre ich, dass diese Arbeit weder in gleicher noch in ähnlicher Form bereits anderen Prüfungsbehörden vorgelegen hat.

Weiter erkläre ich, dass ich mich an keiner anderen Hochschule um einen Doktorgrad beworben habe.

Göttingen, den 18.März 2014

Antje Reinhardt

2. Hiermit erkläre ich eidesstattlich, dass diese Dissertation selbständig und ohne unerlaubte Hilfe angefertigt wurde.

Göttingen, den 18.März 2014

Antje Reinhardt 


\section{Declaration of the author's own contribution to manuscript with multiple}

\section{authors}

The chapters 2 to 4 are a series of manuscripts that have or will be submitted to peer-reviewed journals. I am the main author of these manuscripts.

I have personally collected, investigate, and analyzed the data for all manuscripts. I

got help from Dr. Katharina Lohaus, Dr. Ines Vollhardt and Philip Schröder to collect the data sets of the field and semi-field trails. I developed the main ideas presented in these manuscripts, and written all manuscripts. Furthermore, I made the tables, figures, and appendices.

At the working group of Prof. Dr. Andreas von Tiedemann, especially Dr. Magdalena Siebold, worked with me at the soil warming experiment by using the same plants as data source.

The working group of Prof. Dr. Stefan Schütz, especially Dr. Maximilian von Fragstein und Niemsdorff, helped with the analysis of the headspace analysis and with the statistical analysis of this chapter. Headspace profiles were composed by Christine Rachow. My supervisors gave helpful remarks for the discussion and writing of all manuscripts.

\section{Declaration plagiarism}

I hereby confirm that I have written this doctoral thesis independently. I have not used other sources or facilities others than the ones mentioned. Moreover, I have not used unauthorized assistance and that I have not submitted this thesis previously in any form for another degree at any institution or university.

Göttingen, den 22. Mai 2015 